\title{
O Direito Financeiro e a redução de desigualdades
}

Tese apresentada à Banca Examinadora do Programa de Pós-Graduação em Direito, da Faculdade de Direito da Universidade de São Paulo, como exigência parcial para obtenção do título de Doutor em Direito, na área de concentração Direito Econômico e Financeiros, sob a orientação do Prof. Associado Fernando Facury Scaff. 


\section{Catalogação da Publicação Serviço de Biblioteca e Documentação Faculdade de Direito da Universidade de São Paulo}

Silveira, Alexandre Coutinho da

O direito financeiro e a redução de desigualdades / Alexandre Coutinho da Silveira ; orientador Fernando Facury Scaff -- São Paulo, 2018.

530

Tese (Doutorado - Programa de Pós-Graduação em Direito Direito Econômico, Financeiro e Tributário) - Faculdade de Direito, Universidade de São Paulo, 2018.

1. Direito Financeiro. 2. Desigualdades. 3. Progressividade. 4. Redistribuição. 5. Tributação. I. Scaff, Fernando Facury, orient. II. Título. 


\title{
O DIREITO FINANCEIRO E A REDUÇÃO DE DESIGUALDADES
}

\begin{abstract}
Tese apresentada à Banca Examinadora do Programa de Pós-Graduação em Direito, da Faculdade de Direito da Universidade de São Paulo, como exigência parcial para obtenção do título de Doutor em Direito, na área de concentração Direito Econômico e Financeiro, sob a orientação do Prof. Associado Fernando Facury Scaff.
\end{abstract}

Aprovado em:

BANCA EXAMINADORA:

Professor(a):

Instituição: Faculdade de Direito da Universidade de São Paulo

Assinatura:

Professor(a):

Instituição: Faculdade de Direito da Universidade de São Paulo

Assinatura:

Professor(a):

Instituição:

Assinatura:

Professor(a):

Instituição:

Assinatura:

Professor(a):

Instituição:

Assinatura: 

A ela, Bruna, meu amor, minha cúmplice e companheira. Que me trouxe, dentre tanta coisa boa, ele, o Antônio, meu filho muito amado, a quem dirijo minhas melhores intenções. 



\section{Agradecimentos}

Agradeço sobretudo à Bruna e ao Antônio, que fizeram leve o fardo. Que mitigaram a solidão dessa empreitada. Que me permitiram terminar essa tese, muito a seu custo pessoal. Que acreditaram.

Agradeço e devo aos meus pais, Reynaldo e Cláudia, o amparo constante, nos mais diversos âmbitos, que me permitiu chegar aqui. Aos meus irmãos, Daniel, Filipe e Marcelo, o apoio. Aos meus sobrinhos Victória, Fernanda e Heitor, Leonardo, Luísa, Isabela e Cecília, a renovação. Especialmente, aos meus afilhados Pedro Braga Martins e Betina Avertano Rocha da Silveira, dois seres humanos encantadores que tenho o privilégio de ver crescer.

Agradeço ao meu orientador, Fernando Facury Scaff, não só o apoio e as lições, como o amplo acesso à biblioteca. Aos amigos Scaff e Denise, muito agradeço a acolhida sempre gentil e generosa.

Agradeço aos amigos que me toleraram e ajudaram, especialmente na pessoa da Isabela Morbach, sempre presente e disposta.

Agradeço ao escritório Silveira, Athias, Soriano de Mello, Guimarães, Pinheiro \& Scaff, a paciência e a confiança.

Agradeço aos professores da FDUSP, na pessoa do Prof. Titular Régis Fernandes de Oliveira, e à Profa. Marta Arretche, do DCP/USP, sinceros na missão acadêmica de pensar e fazer pensar.

Os agradecimentos são sinceros e merecidos. As falhas, impropriedades e incoerências do trabalho são, contudo, única e exclusivamente do autor. 

"La majestueuse égalité des lois, qui interdit au riche comme au pauvre de coucher sous les ponts, de mendier dans les rues et de voler du pain”. Anatole France, Le Lys rouge (1984).

"Porque se multiplicará a iniquidade, vai resfriar o amor de muitos”. Mateus, 24,12.

"All good people agree,

And all good people say,

All nice people, like Us, are We

And every one else is They:

But if you cross over the sea,

Instead of over the way,

You may end by (think of it!) looking on We

As only a sort of They!"

Rudyard Kipling, We and They, publicado em Debits and Credits (1926). 



\section{Resumo}

Esta tese tem por objetivo questionar, por meio do Direito Financeiro, as consequências jurídicas de observar a atividade financeira do Estado a partir do objetivo constitucional de redução de desigualdades. Para tanto, inicialmente são abordadas algumas objeções sobre o tema das desigualdades - fixando que reduzir desigualdades é possível e depende de escolhas políticas; que as desigualdades no Brasil continuam apresentando índices muito altos e estáveis; que a redução dessas desigualdades é um imperativo econômico, político e social; que a atividade financeira do Estado pode e deve servir, como outros meios, para promover esta redução de desigualdades. Na sequência, buscam-se dados de realidade sobre o papel desconcentrador dos instrumentos financeiros do Estado brasileiro: no âmbito da receita pública, do federalismo fiscal e do endividamento público; encontram-se instrumentos que atuam em sentido desconcentrador, instrumentos que não participam deste objetivo e instrumentos que, indireta ou diretamente, atuam no sentido inverso, promovendo mais desigualdade - o objetivo constitucional, quando buscado na atividade financeira do Estado, revela diversas frustrações. Com essas considerações, pondo a redução de desigualdades como protagonista, a tese visa identificar, selecionar e analisar os temas jurídicos surgidos, para isso dividindo-os em quatro categorias: tomando o direito (i) como objetivo, (ii) como ferramenta, (iii) como arranjo institucional e (iv) como vocalizador de demandas. Analisando o tema no interior dessas categorias, conclui-se que, ao lançar ao centro das preocupações jurídico-financeiras o objetivo constitucional de redução de desigualdades, encontramos novos debates a propor, além de ganho jurídico-argumentativo em outros debates já conhecidos.

Palavras-chave: Direito Financeiro, atividade financeira, instrumentos financeiros, desigualdades, concentração, regressividade, progressividade, redistribuição, objetivo constitucional, tributação, federalismo, endividamento público. 



\begin{abstract}
This thesis aims to question, through Public Finance Law, the legal consequences of observing States's financial activity using the constitutional objective of reducing inequalities. Therefore, we approach initially some objections against the issue of inequalities - fixing that inequality reduction is possible and depends on political choices; that inequalities in Brazil continue to present levels extremely high and stable; that reducing these inequalities is necessary from the economic, political and social stands; that the State's financial activity can and must serve, as other means do, to promote the reduction of inequalities. In sequence, we search for reality data about the progressive role of the Brazilian States's financial instruments: within public revenue, fiscal federalism and public indebtedness; we find instruments that act in a progressive way, instruments that do not participate to achieve the objective and instruments that, directly or indirectly, act in the reverse way, promoting more inequality - the constitutional objective, when searched in the State's financial activity, reveals various frustrations. From these considerations, taking the reduction of inequalities in a leading role, this thesis aims to identify, select and analyze legal issues emerged, dividing them into four categories: taking Law (i) as objective, (ii) as tool, (iii) as institutional arrangement and (iv) as demand vocalizer. Analyzing issues within these categories, we can conclude that, when putting the constitutional objective of inequality reduction in the center of legal-financial concerns, we find new debates to propose, besides legal-argumentative gain in other debates already in place.
\end{abstract}

Key words: Public Finance Law, financial activity, financial instruments, inequalities, concentration, regressivity, progressivity, redistribution, constitutional objective, taxation, federalism, public indebtedness. 



\section{Résumé}

Cette thèse vise à interroger, par le biais du droit financier, les conséquences juridiques de l'observation de l'activité financière de l'État à partir de l'objectif constitutionnel de réduction des inégalités. Pour ce faire, des objections sont d'abord soulevées sur la question des inégalités - affirmant que la réduction des inégalités est possible et dépend des choix politiques; que les différentes mesures d'inégalité au Brésil continuent de montrer des taux très élevés et stables; que réduire ces inégalités est un impératif économique, politique et social; que l'activité financière de l'Etat peut et doit servir, comme d'autres moyens, à promouvoir cette réduction des inégalités. Dans l'ordre, nous recherchons des données issues de la réalité sur le rôle déconcentrant des instruments financiers de l'État brésilien dans le domaine des recettes publiques, du fédéralisme fiscal et de la dette publique. Il y a des instruments qui agissent dans un sens déconcentré, des instruments qui ne participent pas à cet objectif et des instruments qui agissent indirectement ou directement dans la direction opposée, favorisant plus d'inégalité. L'objectif constitutionnel, lorsqu'il est recherché dans l'activité financière de l'Etat, révèle plusieurs frustrations. Avec ces considérations, en mettant en avant la réduction des inégalités comme protagoniste, la thèse vise à identifier, sélectionner et analyser les problèmes juridiques qui se sont posés en les divisant en quatre catégories : prendre le droit comme (i) un objectif, (ii) un outil, (iii) un arrangement institutionnel et (iv) un vocalisateur des demandes. Analysant le thème au sein de ces catégories, on conclut qu'en plaçant l'objectif constitutionnel de réduction des inégalités au centre des préoccupations juridiques et financières, on trouve de nouveaux débats àproposer ainsi que des avancées juridiques et argumentatives dans d'autres débats déjà connus.

Mots-clés: Droit financier, activité financière, instruments financiers, inégalités, concentration, régressivité, progressivité, redistribution, objectif constitutionnel, fiscalité, fédéralisme, endettement public.. 



\section{SUMÁRIO}

INTRODUÇÃO ..

1. DESIGUALDADES: CABE AO ESTADO REDUZI-LAS E ÀS FINANÇAS PÚBLICAS PARTICIPAR. .31

1.1. AS DESIGUALDADES SÃO RESULTADO DE ESCOLHAS. 31

1.2 . EVOLUÇÃO DA DESIGUALDADE NO PASSADO RECENTE (OU: COMO MEDIR A DESIGUALDADE?). 39

1.3. POR QUÊ BUSCAR A REDUÇÃO? .56

1.4. QUAIS SÃO AS FORMAS DE PROMOVER SUA REDUÇÃO? OU: REDUÇÃO DE DESIGUALDADES SE DÁ APENAS POR MEIO DO GASTO?.

2. INSTRUMENTOS DA ATIVIDADE FINANCEIRA DO ESTADO E A REDUÇÃO DE DESIGUALDADES..........87

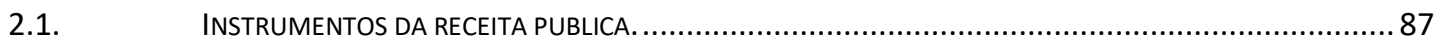

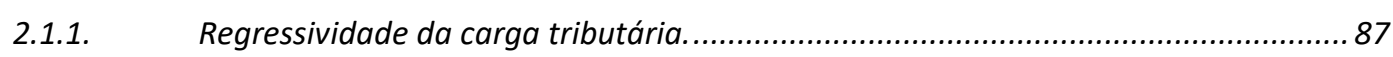

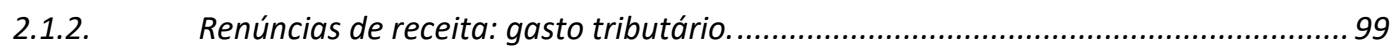

2.1.3. Gasto tributário - o caso do SIMPLES Nacional................................................ 133

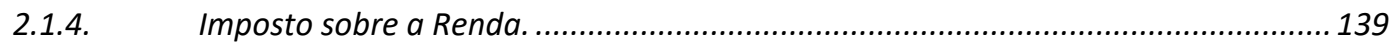

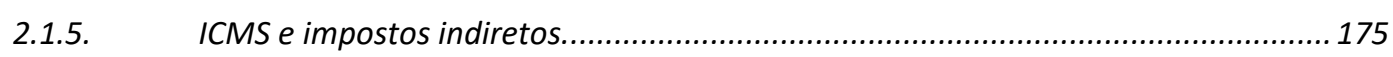

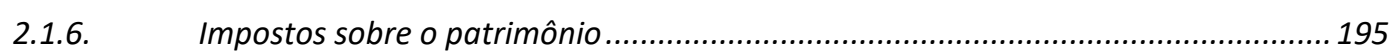

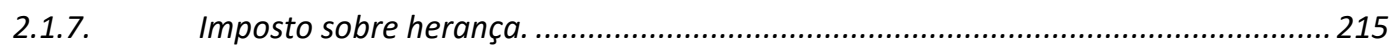

2.1.8. A regra de não-vinculação da receita de impostos.............................................. 233

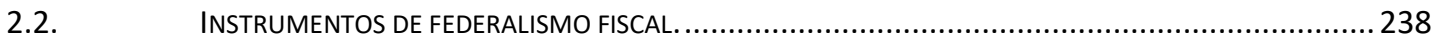

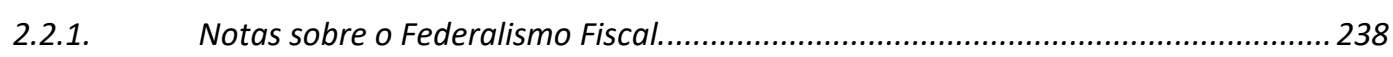

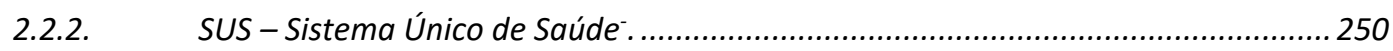

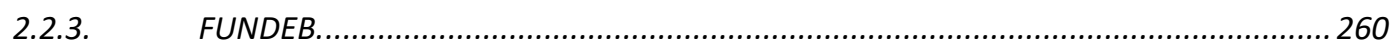

2.2.4. Fundo de Participação dos Estados - FPE....................................................... 269

2.2.5. Fundo de Participação dos Municípios - FPM. .................................................. 277

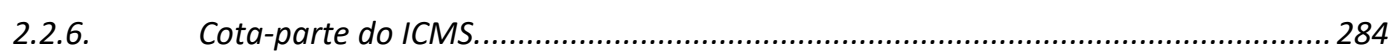

2.2.7. PNDR - Política Nacional de Desenvolvimento Regional....................................... 289

2.2.8. Transferências voluntárias (setores não regulados)........................................... 294

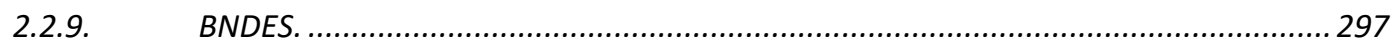

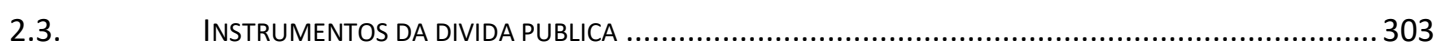

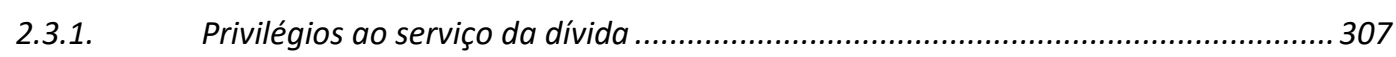

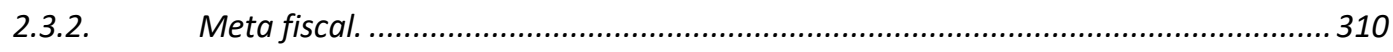

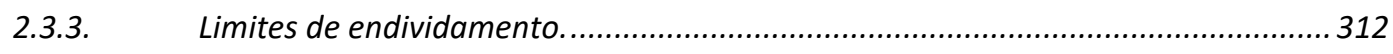

2.3.4. Renegociação das dívidas dos entes subnacionais. Garantias ofertadas pela União. 314

2.3.5. Endividamento às escondidas. 
3. EXAME JURÍDICO DOS INSTRUMENTOS FISCAIS-FINANCEIROS: SOB O ÂNGULO DO OBJETIVO CONSTITUCIONAL DE REDUÇÃO DE DESIGUALDADES.

3.1. O DIREITO ENQUANTO OBJETIVO.

3.1.1. Sobre o papel e função do Direito Financeiro, considerando especialmente os privilégios ao serviço da dívida e o valor jurídico da meta de superávit primário. Sobre os Direitos Financeiro e Tributário, considerando a análise da tributação como elemento da atividade financeira do Estado. 323

3.1.2. O conteúdo do objetivo constitucional de redução de desigualdades. 346

3.1.3. Controle de constitucionalidade. 352

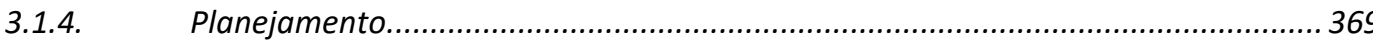

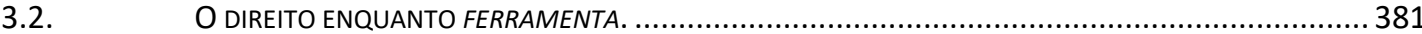

3.2.1. Tributação e progressividade no Brasil................................................................... 382

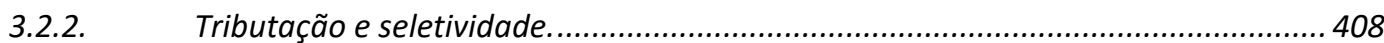

3.2.3. O desuso total ou parcial de tributos com ênfase redistributiva............................ 416

3.2.4. Igualdade tributária. O caso do Simples Nacional............................................ 427

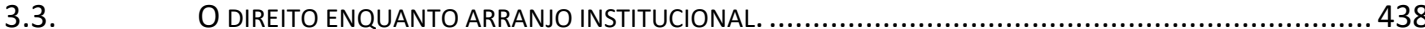

3.3.1. Demanda de conteúdo redistributivo nos Fundos de Participação. Inconstitucionalidade do FPM.

3.3.2. Demanda de conteúdo redistributivo nos demais instrumentos de partilha. A descentralização via SUS e FUNDEB. O caráter regional dos financiamentos do BNDES.

3.3.3. Face distributiva da regra de não-vinculação da receita de impostos: impacto em

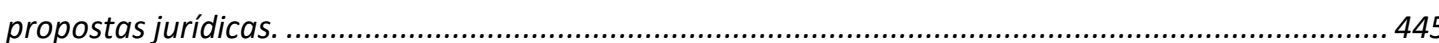

3.4. O DIREITO ENQUANTO VOCALIZADOR DE DEMANDAS..................................................... 452

3.4.1. Transparência, publicidade. Controle, acompanhamento. Gasto tributário. .......... 452

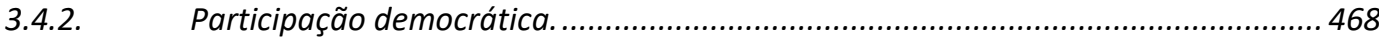

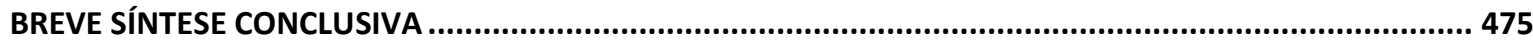

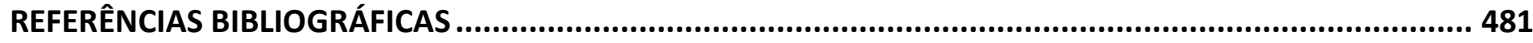




\section{INTRODUÇÃO}

O dinheiro fala. Isso é verdade nas relações privadas e é verdade, também, na atividade financeira do Estado. O comportamento financeiro do Estado denuncia suas intenções, revela seus propósitos ${ }^{1}$. Daí que uma das formas de observar se o Estado cumpre o que promete ou efetivamente se engaja nas suas declarações de princípios e diretrizes é analisando sua atividade financeira ${ }^{2}$.

Um caso recente ajuda a perceber do que falamos: a Lei Orçamentária Anual de 2016 previu cortes profundos no Orçamento da Justiça do Trabalho. O Relator do Projeto de Lei (PLN no 07/2015-CN), em seu Parecer Final, fez diversas considerações sobre direitos materiais e processuais trabalhistas que entende exagerados ${ }^{3}$. O caso é lembrado nesta

1 “O direito financeiro é uma das áreas do conhecimento humano mais adequada para os estudos acerca da república, pois é nela que o Estado estrutura e o governo efetua a arrecadação e realiza a despesa pública, operações que permitirão constatar como se realiza a atuação governamental". SCAFF, Fernando Facury. Orçamento republicano e liberdade igual: direito financeiro, república e direitos fundamentais. Tese (Concurso para provimento do cargo de Professor Titular de Direito Financeiro). Faculdade de Direito da Universidade de São Paulo. São Paulo, 2017. p. 101.

2 "Amid the clashing of divergent interests and the endeavor of each social class to roll off the burden of taxation on some other class, we discern the slow and laborious growth of standards of justice in taxation, and the attempt on the part of the community as a whole to realize this justice. The history of finance, in other words, shows the evolution of the principle of faculty or ability to pay - the principle that each individual should be held to help the state in proportion to his ability to help himself'. SELIGMAN, Edwin R. A. The income tax: a study of the history, theory, and practice of income taxation at home and abroad. New York : The Macmillan Company, 1911. p. 04.

3 Criticou as regras atuais porque "estimulam a judicialização dos conflitos trabalhistas", "são extremamente condescendentes com o trabalhador", "as causas são apresentadas com valores completamente desproporcionais", a possibilidade de reapresentação da demanda seria viciosa ("prazo de dois anos é excessivo , uma vez que estimula o ex-empregado, que já havia recebido sua rescisão, a buscar ganhos adicionais diante de dificuldades financeiras") e seria necessário "estabelecer que o acordo no sindicato tem que valer como quitação". O documento, datado de 13 de dezembro de 2015 e disponível no sítio da Câmara dos Deputados, é firmado pelo Relator-Geral do PLOA/2016, Deputado Federal Ricardo Barros (PP/PR). Tendo sido a Lei aprovada com estas considerações (Lei n. 13.255/2016), foi objeto de Ação Direta de Inconstitucionalidade no STF (ADIN n. 5468), que veio a ser relatada pelo Min. Luiz Fux; o argumento central da ação era de desvio de finalidade. Por maioria, o Plenário do STF manteve a validade da norma, em especial deferência à autonomia do Poder Legislativo; coonsiderou, dentre outras razões, que "O relatório da Comissão Mista de Planos, Orçamentos Públicos e Fiscalização (CMO) do Congresso Nacional, mercê de ostentar confessadamente, motivação ideologicamente enviesada, não vincula, per si, a apreciação pelas Casas Legislativas do Parlamento Federal (...) O desvio de finalidade tem como referência conceitual a ideia de deturpação do dever-poder atribuído a determinado agente público que, embora atue aparentemente dentro dos limites de sua atribuição institucional, mobiliza a sua atuação à finalidade não imposta, ou não desejada pela ordem jurídica, ou pelo interesse público. 9) $\mathrm{O}$ abuso parlamentar não se configura, sob o ângulo da principiologia dos subprincípios da proporcionalidade (necessidade, adequação e proporcionalidade em sentido estrito), quando imposta a redução do orçamento público destinado a órgãos e programas orçamentários, em decorrência de de crise econômica e fiscal" (ADI 5468, Rel. Min. Luiz Fux, Tribunal Pleno, j. 30 jun. 2016). 
ocasião porque representa parcela daquilo que motiva esta pesquisa: o uso da via financeira para sufocamento oblíquo de direitos sociais. E diz-se oblíquo porque ao Deputado Federal Relator do PLOA/2016 é dado redigir projetos e levar a plenário discussões a respeito das regras materiais e processuais que critica; mas ao deixar de pôr o tema em discussão, em vez disso se usando da via financeira para atingir o mesmo resultado, burla as instituições existentes, promove um bypass da deliberação democrática ordinária.

Com esta postura em mente, selecionamos um dos objetivos fundamentais da Constituição Federal de 1988 - o de redução de desigualdades sociais (art. 3º , III) - para perquirir se a atividade financeira tem se engajado na sua busca.

A eleição deste objetivo constitucional em específico parece natural. Como teremos a oportunidade de apontar, o tema é dos mais controvertidos atualmente. O Brasil é, seguidamente, detentor de alguns dos piores níveis mundiais de desigualdades - o que nos traz a oportunidade de analisar o tema por dentro. E estas desigualdades causam diversos prejuízos ao regular funcionamento do Estado e da sociedade, representando um verdadeiro e legítimo objeto de preocupação e estudo acadêmico.

Fixada essa ideia, a primeira tarefa a desempenhar é de buscar um diagnóstico sobre o cruzamento dos instrumentos da atividade financeira do Estado com o propósito, constitucionalmente delineado, de reduzir desigualdades. Mas não é este, ainda, o propósito da tese. O diagnóstico, para estes propósitos, é apenas um degrau.

Quer-se, isto sim, a partir dele, encontrar e desenvolver as polêmicas jurídicas que se fazem presentes quando os temas de Direito Financeiro são invadidos pela condição, enquanto protagonista, do objetivo de reduzir desigualdades. A ideia é que aquele objetivo, frequentemente negligenciado no campo financeiro, traz diversas repercussões ao Direito. É na exploração dessas repercussões que a tese pretende avançar: lançando foco sobre os meios hodiernos da atividade financeira do Estado que (i) sejam voltados ao mencionado objetivo, (ii) sejam contrários ao objetivo, (iii) contenham o objetivo em maior ou menor grau, (iv) sejam indiferentes ao objetivo ${ }^{4}$. E, a partir deste levantamento, passar a criticar juridicamente

4 Comparato ensina: “o juízo de validade de uma política - seja ela empresarial ou governamental - não se confunde nunca com o juízo de validade das normas e dos atos que a compõem. Uma lei, editada no quadro de determinada política pública, por exemplo, pode ser inconstitucional, sem que esta última o seja. Inversamente, determinada política governamental, em razão de sua finalidade, pode ser julgada 
estes instrumentos, sua estrutura institucional, seu relacionamento com diversos valores jurídicos circundantes, a partir do reflexo no objetivo em comento.

A pretensão é de apresentar uma ferramenta de análise: observar os debates jurídicos pela lente do objetivo constitucional de redução de desigualdades, encontrando novas formas de pensar o direito fiscal. Este é o espaço que se busca ocupar no plano jurídico ${ }^{5}$. Afinal, "embora a desigualdade dos países da América Latina seja um fato amplamente conhecido, as políticas públicas, e especialmente as fiscais, não se tem orientado a este objetivo com a força requerida"

Cabe apontar, então, desde o princípio, algumas limitações que serão observadas.

A primeira delas diz respeito ao escopo da atividade financeira analisada. É que, com Fernando Facury Scaff, o Direito Financeiro pode ser dividido em 06 (seis) subáreas de estudo: é o ramo destinado a estudar como o Estado (i) arrecada (receita pública), (ii) reparte (federalismo fiscal), (iii) gasta (despesa pública) e (iv) se endivida (crédito público), e como tudo isso (v) é organizado (orçamentos públicos) e (vi) fiscalizado (fiscalização financeiro-

incompatível com os objetivos constitucionais que vinculam a ação do Estado, sem que nenhum dos atos administrativos praticados, ou nenhuma das normas que a regem, sejam, em si mesmos, inconstitucionais". COMPARATO, Fabio Konder. Ensaio sobre o juízo de constitucionalidade de políticas públicas. p. 45.

5 “As estruturas da desigualdade podem ser, se não modificadas, bastante perturbadas na sua inércia conservadora, mediante processos jurídico-institucionais bem articulados". BUCCI, Maria Paula Dallari. Fundamentos para uma teoria jurídica das políticas públicas. p. 30.

6 HANNI, Michael; MARTNER, Ricardo; PODESTÁ, Andrea. El potencial redistributivo de la fiscalidad en América Latina. Revista CEPAL, n. 116, ago./2015. p. 08. Nas suas conclusões, colocam: "En América Latina, la política fiscal juega aún un papel limitado a la hora de mejorar la distribución del ingresso disponible. Si bien los países de la región parten de niveles de desigualdad de los ingresos de mercado solo levemente superiores a los de la ocde, la política fiscal en estos últimos cumple un papel significativo en la reducción de la desigualdad, ya que el coeficiente de Gini baja un 36\% luego de las transferencias e impuestos directos, en comparación con solo un $6 \%$ en los países latino-americanos (...) La evaluación del efecto redistributivo de estas potenciales reformas comprueba la importancia de promover acciones que combatan la evasión y elusión fiscal (en especial del impuesto sobre la renta personal); de otorgar a las rentas de capital un tratamiento similar al aplicado a las rentas provenientes del trabajo; de reducir los tratamientos preferenciales y rebajar el nivel de ingreso a partir del cual se aplican las tasas máximas en concordancia con los rangos estabelecidos en otras regiones. (...) En conclusión, los resultados de este estudio sugieren que uno de los grandes desafíos que sigue enfrentando la región es mejorar el poder redistributivo de la política fiscal, tanto en lo que se refiere a los impuestos como a los gastos, a objeto de promover una mayor igualdad en la distribución del ingreso disponible y una mayor reducción de los niveles de pobreza (...) Por supuesto, y como lo ha enfatizado la cepal en su trilogía de la igualdad, es menester desplegar múltiples iniciativas para el cambio estructural con igualdad. Pero, sin duda, las políticas fiscales redistributivas han de contribuir en el futuro a cambiar este estigma regional" - p. 25 . 
orçamentária) $^{7}$ - tudo visando a persecução dos objetivos constitucionais. Assim, seria inviável, nesta ocasião, perquirir o cumprimento do objetivo constitucional no interior de cada uma destas categorias, especialmente considerando a vastidão de itens de despesa pública.

Sendo assim, focam-se em três itens da atividade financeira para neles promover esta análise: (i) a receita pública, (ii) o federalismo fiscal e (iii) a dívida pública. É no interior destes itens que serão selecionados instrumentos, visando compreender se têm sido orientados para reduzir desigualdades ou não.

A segunda limitação que deve ser observada é de que tampouco serão buscadas outras políticas de redução de desigualdades que, embora muito caras ao esforço de atingir o objetivo constitucional, não transitam (ao menos não diretamente) pela atividade financeira do Estado. É o caso, exemplificativamente, das normas trabalhistas, das regras de salário mínimo $^{8}$ e das normas de reforma agrária.

Como terceira limitação, impõe-se recordar mesmo os contornos do Direito. É que, nada obstante busque-se (também) um diagnóstico sobre a o cumprimento do objetivo de reduzir desigualdades no interior dos instrumentos fisco-financeiros, falta-nos competência ${ }^{9}$ para produzir análises empíricas, próprias das ciências sociais. Sendo assim, no tema, fazemos uso extensivo de trabalhos de outras áreas - especialmente da Economia, Sociologia e Ciência Política - nesse mister. Cabe a observação de Lopes quando aponta que questões

7 SCAFF, Fernando Facury. Orçamento republicano e liberdade igual: direito financeiro, república e direitos fundamentais. Tese (Concurso para provimento do cargo de Professor Titular de Direito Financeiro). Faculdade de Direito da Universidade de São Paulo. São Paulo, 2017. p. 94.

8 “A política que mais efetivamente contribuiu para amortecer a desigualdade na distribuição de renda no Brasil foi a valorização do salário mínimo - é o que emerge de pesquisa empírica recente empenhada em isolar o peso desse fator". KERSTENETZKY, Célia Lessa. Foi um pássaro, foi um avião? Redistribuição no Brasil no século XXI. Novos Estudos CEBRAP, v. 36, n. 02, jul 2017. p. 19.

9 “Ao jurista não cabem especulações sobre quais os modelos de tributação poderiam ser, economicamente, mais eficientes, por ser este critério objeto de análises estranhas ao método da dogmática jurídica. Ao jurista compete a hermenêutica e aplicação do direito tributário. Contudo, o estudo do princípio de capacidade contributiva não pode ser feito sem uma prévia aproximação das doutrinas que o fundamentaram desde a origem, bem assim a forma de divisão dos tributos e os modelos de definição dos critérios de apuração da justiça tributária em cada caso. E este é precisamente o caso da justiça tributária, inicialmente elaborada pelos autores de economia política e que passou aos compêndios de direito financeiro até assumir sua autonomia jurídica, como conteúdo específico do direito tributário". TORRES, Heleno Taveira. A justiça dos tributos. In: DERZI, Misabel Abreu Machado; MELO, João Paulo Fanucchi de Almeida (Coord.). Justiça Fiscal. Belo Horizonte: Del Rey, 2016. p. 236. 
jurídicas podem ser resumidas em "saber se e como alguma coisa, ou melhor dizendo, alguma ação ou algum estado de coisas, é proibido, permitido ou obrigatório de acordo com o direito"10. Quer-se, neste sentido, avaliar segundo este trinômio alguns elementos identificáveis da atividade financeira do Estado, sempre tomando como ponto de partida o diagnóstico de sua relação com o objetivo de reduzir desigualdades.

A título de quarta limitação, tomem-se três ideias que o trabalho não perseguirá: (i) não pretende tão somente repetir os trabalhos de outras áreas de conhecimento, acima mencionados - aquele conhecimento será sempre bem recebido e necessário, mas não suficiente e não configura o cerne; (ii) não pretende levar adiante apenas ideias teóricas (por mais necessárias e interessantes que sejam) sobre desigualdade e a necessidade de reduzilas; (iii) não pretende assumir condição militante, no sentido de afirmar a ilegitimidade de todos os instrumentos financeiros que eventualmente sejam indiferentes ou contrários ao objetivo constitucional de redução de desigualdades: é preciso reconhecer e respeitar o espaço da política, abstendo-se de pretender que todo e qualquer debate possa e deva ser determinado a partir do Direito.

Considere-se finalmente, em quinto item, que o trabalho promove seu recorte metodológico em torno das desigualdades sociais - o ângulo que se quer é do impacto nas pessoas, e não de uma desigualdade entre entes políticos pura e simplesmente considerada. Isto significa que as desigualdades regionais ou territoriais estarão presentes apenas enquanto fatores das desigualdades sociais (afinal, o debate de cunho regional é expressão da necessária preocupação com a sociedade e com o ser humano, na construção política histórica em regiões ${ }^{11}$ ). Não serão analisados frontalmente outros tipos de desigualdade,

10 LOPES, José Reinaldo Lima. Régua e compasso - ou metodologia para um trabalho jurídico sensato. Mimeo. Texto publicado em espanhol como: Reglás y compás. In: COURTS, Christian (org.). Observar la ley, Madrid, Editorial Trotta, 2006. p. 14.

11 "É justamente a exigência de solidariedade do Estado Social que fez com que fosse formulado um princípio de fidelidade federal que vincula a União e os entes federados, condicionando e orientando suas políticas na direção da diminuição das desigualdades sociais. Não é possível, porém, a uniformização das condições sociais de vida entre os vários entes federados se estes não tiverem capacidade suficiente (não apenas econômica, mas, também, política) para satisfazer plenamente todas as suas funções. Assim, a forma cooperativa de federalismo tem por objetivo fundamental a igualação da capacidade dos membros da Federação". BERCOVICI, Gilberto. Constituição econômica e desenvolvimento: uma leitura a partir da Constituição de 1988. São Paulo: Malheiros Editores, 2005. p. 91. 
embora relevantíssimos social e juridicamente, como as desigualdades de gênero, de raça e mesmo entre gerações.

Fixado o tema principal e suas limitações, cabe prosseguir delineando algumas premissas que serão adotadas nos capítulos seguintes.

Como já exposto, quer-se promover análises jurídico-financeiras que surgem ou se revelam mais relevantes quando lançado ao centro das preocupações o objetivo de reduzir desigualdades. Isso implica dizer que buscamos diversas diferentes análises, reputadas subexploradas, dentre debates simplesmente ausentes do cenário nacional ou debates ativos mas que, por não considerarem (ou considerarem apenas marginalmente) a questão distributiva, deixam de abordar razões e argumentos relevantes.

Sendo assim, observados os limites do espaço acadêmico, a tese opta por privilegiar a amplitude, horizontal, de modo a identificar, selecionar e analisar os temas jurídicos surgidos; em detrimento da profundidade, vertical, de cada um dos debates trazidos. Sendo assim, a pretensão do terceiro capítulo não será de esgotar todo o potencial analítico de cada tema (segundo os diversos ramos do Direito que seriam aplicáveis), mas sim expor os diversos temas impactados, afirmando a inovação trazida pela lente utilizada, e buscando abordar especialmente o impacto do objetivo fundamental naquele assunto em particular. Entende-se que a horizontalidade, ora mencionada, permite mais claramente demonstrar que as desigualdades, embora objeto de norma constitucional de estatura superior, não têm sido protagonistas dos debates jurídicos.

Preferindo suscitar diversos debates, em vez de aprofundar um ou alguns, são vários os temas tomados para análise a partir do Direito. A empreitada pode servir-se da ideia a 
respeito dos papéis do direito no desenvolvimento ${ }^{12}$, descritos por Diogo Coutinho ${ }^{13}$. São quatro, na visão do autor: direito como (i) objetivo, (ii) ferramenta, (iii) arranjo institucional e (iv) vocalizador de demandas ${ }^{14}$. Enquanto (i) objetivo, a proposta é de apreciar o conteúdo do comando constitucional de redução de desigualdades, passando então a contemplar os instrumentos do Direito Financeiro segundo este conteúdo; como (ii) ferramenta, quer-se

12 É relevante a posição de Kerry Rittich, analisando o papel do Direito e do jurista no que chama de segunda geração de reformas, pós Consenso de Washington, promovidas pelas instituições financeiras internacionais (especialmente o Banco Mundial), na ânsia de incluir questões sociais na agenda do desenvolvimento, embora mantendo o receituário liberalizante no plano macroeconômico. Coloca: "the fate of the social can only be analyzed through a nuanced and detailed examination of the norms, rules, and institutions that structure the interactions of groups and individuals in particular contexts (...) The ways in which myriad social and economic norms, rules, and institutions may affect the realization of different social objectives are likely to be ignored or vastly underestimated by those, including economists, who are focused on their efficiency-enhancing properties. Or the complex and cross-cutting effects of legal rules and other norms may simply be invisible to those who are unable to adequately assess the variety of outcomes that legal rules can generate in different social and institutional contexts, their interaction with other normative orders, and the conflicting ways that they can be interpreted and adjudicated over time. (...) Disciplinary orientation is part of the story here. Legal scholars could both help fill in the missing links between social concerns and the regulatory agenda in a variety of ways, as part of the 'comparative advantage' of legal scholars in governance and institutional reform debates lies in their capacity to demonstrate these varying possibilities by better explicating the operation of the institutions that can mediate between social norms and social outcomes 'on the ground.' Legal scholars are thus well positioned to illuminate some of the challenges to the realization of social objectives that may remain hidden amidst endorsements of the 'social, structural, and human' at the abstract level but which become clear by focusing not only on efficiency, but on the full range of things rules and institutions actually do. An important part of the task is simply to illustrate the point made at the outset, which is that legal norms and institutions operate in multiple modes: normative, distributive, constitutive, and disciplinary. Another is to observe that the rules that govern economic transactions in industrialized states have always served multiple functions - the enhancement of efficiency is but one. To reduce the focus of the reform of legal rules and institutions to concerns about efficiency and market failures, even assuming that the calculus that underpins these efforts is adequate, is to miss many of their other properties and effects and to radically reduce in scope the aspirations driving legal regulation (...) At minimum, the exercise can provide policymakers with alternative analyses of the context and the alternatives, and aid social justice activists in their efforts to unsettle the soft consensus that has consolidated around the idea that the standard approach to reform is both normal, clearly 'right' and in any event, unchallengeable. In short, legal scholars have a distinct analytic role to play. This is simply to refuse any automatic collapse of the social into the economic project, and to identify in concrete ways how specific elements of the governance project play out in practice and might work at cross-purposes with 'social, structural, and human' ends, however defined". RITTICH, Kerry. The future of law and development: second-generation reforms and the incorporation of the social. In: TRUBEK, David M.; SANTOS, Alvaro (Eds.). The new law and economic development, a critical appraisal. Cambridge University Press: 2006. p. 247, 249-250, 252.

${ }^{13}$ COUTINHO, Diogo R. Direito, desigualdade e desenvolvimento. São Paulo: Saraiva, 2013. Capítulo 3, item 3.2. p. 95 e ss. Tema também abordado em: COUTINHO, Diogo R. O direito nas políticas públicas. In: MARQUES, Eduardo; FARIA, Carlos Aurélio Pimenta de (orgs.). A política pública como campo multidisciplinar. São Paulo: UNESP, 2013.

${ }^{14}$ Interessante observar sua colocação: “o aparato jurídico tem papel redistributivo não negligenciável em políticas públicas. Seja porque molda instituições (como a propriedade) em vários níveis, seja porque as dinamiza, seja porque permite sua avaliação e ajuste, o direito é, como defendido no tópico anterior, em boa medida responsável pelas transferências de riqueza nas sociedades capitalistas”. Ibidem, p. 104. 
utilizar as evidências empíricas encontradas para dizer, juridicamente, sobre a formatação dos meios empregados para alcançar o objetivo constitucional e como esses meios poderiam estar melhor construídos em sua estrutura jurídica ${ }^{15}$; como (iii) arranjo institucional, especialmente no que concerne ao federalismo fiscal, pretende-se extrair lições jurídicas a respeito da interação entre os atores envolvidos, tendo em vista aquele objetivo; como (iv) vocalizador de demandas, a proposta é analisar alguns desses instrumentos dizendo sobre a sua adequação enquanto elemento democratizador ${ }^{16}$, de modo a permitir a participação da sociedade na definição da política.

E, para que se promova esta análise jurídica, uma outra premissa é de relevância ímpar, devendo restar clara porque presente em todo o trabalho: quaisquer que sejam os níveis de cumprimento do objetivo de redução de desigualdades, eles poderão e deverão sofrer críticas. Dir-se-á, por um lado, que a atividade financeira não promove aquele objetivo de maneira suficiente; de outro lado, que promove o objetivo de maneira demasiada, descuidando de outros axiomas igualmente relevantes; ou até mesmo que estes instrumentos financeiros são inadequados à solução política pretendida ${ }^{17}$. Para nossos propósitos, contudo, importa registrar que a análise jurídica encontra seus limites, não podendo substituir-se à decisão política. Como dispõe Piketty, “apenas a deliberação coletiva e a

${ }^{15}$ Interessante observar e analisar juridicamente - o que deverá ser objeto deste item - as propostas comumente colocadas para que o funcionamento dos tributos, como instrumentos não apenas de arrecadação mas de redução de desigualdades. Por exemplo: "Em termos de estrutura geral da tributação, as propostas elevam os impostos coletados sobre a renda, o capital e as transferências de riqueza - o contrário da tendência recente de elevar os impostos sobre o consumo (VAT) e sobre a renda auferida (contribuições para a seguridade social). As propostas são um meio de distribuir o custo do financiamento das operações do governo de forma mais justa e de elevar a arrecadação fiscal adicional para financiar a redistribuição". ATKINSON, Anthony B. Desigualdade: o que pode ser feito? São Paulo: LeYa, 2015. p. 220.

16 Vale referir a experiência narrada por Paul Collier, sobre a inclusão do controle social nas transferências educacionais em Uganda, que conduziu a uma melhora, entre os níveis de valores liberados pelo Ministério, e os recebidos pelas escolas - ou seja, reduzindo os desvios de corrupção -, da casa de $20 \%$ para um patamar de 90\%. COLLIER, Paul. The bottom billion: why the poorest countries are failing and what can be done about it. NY: Oxford University Press, 2008. p. 149-151.

17 Sobre o tema, ver, na perspectiva econômica: SOARES, Sergei Suarez Dillon. O ritmo na queda da desigualdade no Brasil é aceitável? Revista de Economia Política, v. 30, p. 364-380. 2010. E, de maneira mais abstrata: MARKOVITS, Daniel. How much redistribution should there be? Yale Law Journal v. 112, n. 8, 2003. Relatório do FMI coloca: "But when is inequality excessive? There is no easy answer, but it will depend on several country-specific factors, including the growth context in which inequality arises, along with societal preferences" - IMF. Fiscal Monitor: Tackling inequality. out 2017. p. 01. 
experimentação democrática podem desempenhar esse papel"18; Paul Peterson afirma que “o grau exato de redistribuição depende do nível de desenvolvimento econômico do país e do custo de promover redistribuição tanto às liberdades individuais como ao continuado desenvolvimento econômico. Não há uma única melhor solução" ${ }^{19}$; ou ainda Scaff, quando postula que "a necessidade de escolha das metas sociais a serem alcançadas deve ser produto de uma deliberação pública" e que a justiça distributiva é tema "primordialmente político, lateralmente econômico e residualmente jurídico" ${ }^{20}$. Assim, quer-se que o respeito à deliberação político-democrática seja uma constante nessas linhas, deferindo-a papel relevante e evitando sempre invadir-lhe o espaço.

Considera-se que o direito é competente para promover exame aprofundado das normas e instituições subjacentes às políticas, inclusive fiscais ${ }^{21}$, e sua interação com os diferentes objetivos sociais e axiomas jurídicos, contrabalanceando a contundência das

18 PIKETTY, Thomas. O capital no século XXI. Tradução de Monica Baumgarten de Bolle. 1. ed. Rio de Janeiro: Intrínseca, 2014. p. 499.

19 PETERSON, Paul. The Price of Federalism. New York: Brookings Institution Press. 1995. p. 190. Bercovici bem coloca que: "Não se pode, portanto, entender a Constituição fora da realidade política, com categorias exclusivamente jurídicas. A Constituição não é exclusivamente normativa, mas também política; as questões constitucionais são também questões políticas. A política deve ser levada em consideração para a própria manutenção dos fundamentos constitucionais. Na feliz expressão de Dieter Grimm, a Constituição é resultante e determinante da política". BERCOVICI, Gilberto. Constituição e política: uma relação difícil. Lua nova, n. 61, de 2004. p. 24. Como coloca Regis de Oliveira: "os conflitos sociais são absolutamente legítimos. Todos são procedentes. Da dialética é que nasce uma solução que será alterada por outra solução e assim por diante". OLIVEIRA, Regis Fernandes de. Indagação sobre os limites da ação do Estado. São Paulo: Editora Revista dos Tribunais, 2015. p. 255. Vale ainda notar as palavras de Burman: "What is the right level of progressivity? The answer depends on the factors that drive inequality and the costs of taxation". BURMAN, Leonard. Taxes and inequality. Tax Law Review, v. 66, de 2013. p. 591.

20 SCAFF, Fernando Facury. Orçamento republicano e liberdade igual: direito financeiro, república e direitos fundamentais. Tese (Concurso para provimento do cargo de Professor Titular de Direito Financeiro). Faculdade de Direito da Universidade de São Paulo. São Paulo, 2017. p. 286 e 355. Prossegue: "esta [deliberação] é que vai determinar a relação de custo-benefício a ser perseguida, correlacionando os recursos a serem arrecadados e os gastos a serem realizados para seu alcance. E isso é uma construção da sociedade, e não um produto a ser determinado em gabinetes tecnocráticos - esses devem ser auxiliares técnicos e não instâncias decisórias. Nesse ponto, é de extrema importância a aproximação entre o que seja uma deliberação do corpo estatal com as reivindicações da sociedade" - p. 286.

21 Como coloca José Reinaldo Lima Lopes: “A hipótese pode também ser gerada por alguma observação vinda de outras 'disciplinas' ou 'ciências'. Tomemos o caso da economia que contribui com análise dos efeitos da aplicação de certos institutos jurídicos. A análise econômica pode sugerir que certas interpretações dos contratos de concessão, como contratos feitos com o Estado, levam a uma distribuição não eqüitativa de custos sociais (...) O impacto econômico desta decisão - que pode ser medido e analisado pela economia e pelas finanças - pode muito bem servir de padrão de crítica à decisão judicial, já que por meio dele pode-se demonstrar ou negar que a decisão foi tomada com mais ou menos sentido jurídico, que ela violou, ou não violou a regra do tratamento igual perante a lei, e assim por diante". LOPES, José Reinaldo Lima. Régua e compasso. Cit. p. 25. 
recomendações econômicas ${ }^{22}$, especialmente aquelas que indicam a eficiência como valor principal ou até único ${ }^{23}$. A "relegitimação" do direito evidencia que as políticas são construídas a partir de elementos jurídicos, assim demandando a participação do direito e aceitando sua lente como objeto de análise ${ }^{24}$. A manifestação de poder admite a análise do jurista em termos de legitimação da conduta segundo os valores eleitos pela sociedade ${ }^{25}$. O direito é necessário para mediar e traduzir a linguagem constitucional aos diversos ramos jurídicos, especialmente ao financeiro, pondo-nos prontos para ouvir, com estes instrumentos, o que a carga axiológica constitucional e jurídica tem a dizer.

Com essas premissas, vale prosseguir quanto ao método e estrutura.

22 RITTICH, Kerry. The future of law and development. Cit.

23 "A ética da solidariedade é substituída pela ética da eficiência e, dessa forma, os programas de redistribuição de renda, reparação de desequilíbrios sociais e assistência a grupos marginalizados têm encontrado forte resistência na casamata republicana. Não há dúvida de que esse novo individualismo tem sua base social originária na grande classe média produzida pela longa prosperidade e pelos processos mais igualitários que predominaram na era keynesiana. Hoje o novo individualismo encontra reforço e sustentação no aparecimento de milhões de empresários terceirizados e autonomizados, criaturas das mudanças nos métodos de trabalho e na organização da grande empresa". BELLUZZO, Luiz Gonzaga. $O$ capital e suas metamorfoses. São Paulo: Editora UNESP, 2013. p. 176.

24 BUCCI, Maria Paula Dallari. Fundamentos para uma teoria jurídica das políticas públicas. Cit. Coloca a autora: "O que há de novo, com a centralidade do direito relegitimada pela Constituição democrática, é a compreensão de que os instrumentos para a transformação das estruturas se ampliaram muito" (p. 27). E ainda: “(...) a política imbricada com a técnica, a gestão pública institucionalizada e regrada pelo direito. A face política do governo vai se revestindo cada vez mais de uma tessitura jurídica” (p. 34).

25 "La importancia que tiene el campo de los juristas, consiste em la importancia que tiene el ejercicio del derecho, que nos es sino ejercicio del poder; de una parte del poder distribuido em la sociedade. Los juristas adquieren importancia social, porque son los encargados oficialmente, esto es, son formados en la universidad para eso, de decir que és lo que se debe, o no se debe haber. En el mundo moderno no hay autoridade, por suprema que sea, que no disponga de una oficina jurídica que 'autorice', esto es legitime, cualquier acto del funcionario de que se trate (...) La razón es simple: declarar que una norma es válida, lo cual a primera vista parece ser unjuicio "objetivo", no es otra cosa que aceptar, decir, promulgar, la idea de que quien la dictó era quien debía dictarla, y, adernas, que hizo lo que debía, esto es, que cumplió con el procedimiento y siguió los lineamientos de las normas superiores. Porque si no fuera todo esto, entonces no seria una norma válida. Seria 'inconstitucional' (más bien no seria: porque ser válida, para una norma, significa que no es inconstitucional). Por lo tanto, no hay ninguna manera de establecer 'objetivamente' la existência de una norma. Hacerlo significa, siempre, intervenir en el fenómeno dei poder. Cada vez que un jurista dice que existe una norma, legitima la conducta de alguien; alguien que, por eso mismo, es un funcionário y no un usurpador; alguien que produjo un acto 'jurídico' y no un delincuente. La activídad jurídica consiste en reconocer el derecho. Pero reconocer el derecho significa, como función social, otorgar legitimidad a la conducta de alguien. Los que los juristas hacen, y eso aprenden a hacer en la facultad, es usar normas para otorgar - pero también quitar - legalidad, y por tanto legitimidad, a la conduta de alguien". CORREAS, Óscar. Introdução: El neoliberalismo en el imaginario juridico. In: MARQUES NETO, Agostinho Ramalho; COUTINHO, Jacinto Nelson de Miranda; RAMOS FILHO, Wilson; GOMES, Manoel Eduardo Alves Camargo e; FACHIN, Luiz Edson. Direito e neoliberalismo: elementos para uma leitura interdisciplinar. Curitiba: EDIBEJ, 1996. p. 11-12. 
O problema central da pesquisa reside na observação de que os instrumentos financeiros não têm sido utilizados, no Brasil, com efeitos redistributivos, mas com efeitos concentradores de renda e incrementadores das desigualdades sociais ou mantenedores do status quo.

A pergunta central a que se pretende responder é: quais debates jurídicos são influenciados quando alçada a primeiro plano a busca por redução de desigualdades a partir dos atividade financeira do Estado? Navega-se sob a ideia de que o trabalho acadêmico pode muito contribuir formulando perguntas corretas e intrigantes do ponto de vista jurídico, promovendo debate sobre temas de interesse, não explorados ou subexplorados. A leitura a partir do Direito Financeiro - no que se dirige organizadamente ao conjunto de normas que forma e faz funcionar a atividade financeira do Estado - está em posição privilegiada para promover estas discussões.

A hipótese de trabalho é a de que o desenho institucional infralegal frustra os ditames da Constituição quanto ao tema das desigualdades e esta análise dos instrumentos fiscais é capaz de ofertar outras perspectivas para diversos debates jurídicos, atualmente não ou pouco explorados. Quer-se ofertar uma lente de análise - leitura jurídica da atividade financeira tomando o objetivo de reduzir desigualdades como protagonista -, suscitando diversas questões relevantes que daí decorrem e que usualmente ficam à margem.

Descortinando as nuances distributivas ou concentradoras dos diversos instrumentos financeiros, é possível alcançar debates jurídicos relevantes, que de outra maneira permanecem submersos especialmente em questões de política, burocracia e eficiência. A visão destes instrumentos a partir do Direito Financeiro oferta muitas perguntas e algumas respostas que devem ser postas à deliberação.

Para desenvolvimento das razões, dividimos o trabalho em três capítulos.

O primeiro introduz algumas ideias básicas, subsidiando a compreensão dos demais, afastando alguns (pré)conceitos reputados equivocados e que frequentemente obstam ou dificultam o debate desses temas. Especialmente, discute-se a (in)evitabilidade das desigualdades e a possibilidade e adequação de usar de instrumentos fiscais (tributos dentre eles) para reduzir desigualdades; apresentam-se dados a respeito da evolução das 
desigualdades no Brasil; fixa-se, por diversas razões (além do cumprimento da ordem constitucional) a necessidade imperativa de promover aquele objetivo fundamental.

O segundo capítulo seleciona instrumentos fisco-financeiros, da receita, do federalismo e da dívida, buscando neles o caráter concentrador, desconcentrador ou neutro. A ideia é de identificar esse caráter em tantos instrumentos quanto for possível (com dados disponíveis), embora sem pretensão de exaustão.

O terceiro capítulo pretende, com as premissas do primeiro e os dados do segundo, identificar, selecionar e apreciar debates jurídicos daí decorrentes. Aqui uma vez mais temse que não serão exauridos os debates existentes e nem mesmo todos os instrumentos do capítulo segundo merecerão análise individual. Nada obstante, a ideia é selecionar alguns daqueles instrumentos para, a partir do seu status do ponto de vista da redução de desigualdades, questionar quais questões jurídicas advém e como elas devem ser tratadas.

Breve conclusão segue ao final.

Espera-se, com essas ideias, suprir o que percebemos como uma lacuna nas análises jurídicas cruzadas com a ideia de redução de desigualdades: a ausência de consideração desse objetivo constitucional na apreciação dos instrumentos fisco-financeiros do Estado brasileiro.

Todas as obras em língua estrangeira referidas no corpo do texto foram traduzidas pelo próprio Autor. Os rodapés foram mantidos na língua original. 


\section{BREVE SÍNTESE CONCLUSIVA}

A principal conclusão que se pode alcançar ao final destas linhas é que, ao lançar ao centro dos debates jurídico-financeiros o objetivo constitucional de redução de desigualdades, verifica-se que os instrumentos financeiros, ao menos parcialmente, frustram o objetivo de reduzir desigualdes; e, a partir disso, são encontrados novos debates a propor, além de ganho jurídico-argumentativo em outros debates já conhecidos.

Este exercício de reposicionamento permite remover objeções ultrapassadas sobre o tema das desigualdades; permite questionar aos instrumentos fisco-financeiros sobre seu papel na busca por redução de desigualdades, extraindo respostas por vezes surpreendentes; permite, ao final, promover novas análises jusfinanceiras, em diversos âmbitos.

Afirma-se, então, que reduzir desigualdades é possível e depende de escolhas políticas à disposição da sociedade na pauta de debates; que as desigualdades no Brasil, embora tenham recentemente sido promovidas à ribalta dos debates públicos, continuam observando índices muito altos e surpreendentemente estáveis; que a redução dessas desigualdades é um imperativo não apenas ideológico, mas econômico, político e social; que a atividade financeira do Estado pode e deve servir, como outros meios, para promover esta redução de desigualdades.

Mas ainda assim, investigação sobre o papel desconcentrador dessa atividade revela muitos percalços. Se de um lado encontramos instrumentos financeiros e fiscais que atuam nesse sentido desconcentrador (como as alíquotas interestaduais no âmbito do ICMS, a regra de não-vinculação da receita de impostos, parte do sistema de transferências, com destaque para SUS, FUNDEB e a Política Nacional de Desenvolvimento Regional), temos outros tantos instrumentos que não participam deste objetivo (como é o caso do desuso parcial de tributos mais aptos à redistribuição, no campo tributário; é o caso da cota-parte de ICMS, no campo das transferências; é o caso dos limites estanques de endividamento, no campo do endividamento) ou que, indireta ou diretamente, atuam no sentido inverso, promovendo mais desigualdade (é o caso de diversos itens da pauta tributária, como o foco em tributos indiretos regressivos, o amplo uso de gastos tributários, a tributação sobre rendas do capital, a falha seletividade do ICMS e os amplos regimes de substituição tributária; no âmbito do federalismo, as transferências do BNDES e do FPM; no campo da dívida pública, os 
privilégios manifestos ao serviço da dívida e ao alcance da meta fiscal, além da renegociação de dívidas de entes subnacionais). Assim, o objetivo constitucional de reduzir desigualdades, quando buscado na atividade financeira do Estado, revela diversas frustrações.

Cabe, então, investigar juridicamente essas frustrações, o que (re)abre diversos debates jusfinanceiros. No interior destes debates, conclui-se:

a) Quanto ao papel da atividade financeira do Estado e do Direito Financeiro:

i. Que não são apenas meios de viabilizar o atingimento dos objetivos constitucionais, mas também atuam, em si próprios, na busca por esses objetivos;

ii. Que o Direito Financeiro foi capturado por concepções ideológicas que direcionam a um privilégio exacerbado, e constitucionalmente desamparado, ao serviço da dívida;

iii. Que a meta fiscal permite existência de metas de déficit e que o não atingimento da meta não importa em crime ou ilícito de qualquer ordem;

iv. Que, na fronteira entre os Direitos Financeiro e Tributário, cabe ao primeiro reclamar parte dos temas que tem deixado à análise do segundo e/ou cabe ampliar o objeto de conhecimento do segundo, para que não mais contemple tão somente a relação exacional, mas passe a olhar à tributação de forma lata;

b) Quanto ao conteúdo jurídico do objetivo constitucional de reduzir desigualdades, que contém especial carga normativa, relacionada à razão mesmo de existência do Estado;

c) Quanto ao controle de constitucionalidade dos instrumentos financeiros, que embora necessário respeitar o espaço da política, é possível afirmar a inconstitucionalidade de alguns instrumentos que maculam o objetivo de reduzir desigualdades (como a estrutura do Fundo de Participação dos Municípios e a estrutura de alíquotas antagônica à seletividade) e é possível também se utilizar de técnicas constitucionais de desbloqueio institucional, para ação como catalisador deliberativo;

d) Quanto planejamento estatal, que é possível fazer uso de meios judiciais, incluindo a ação de inconstitucionalidade por omissão, para demandar que o planejamento seja, ao menos, desenhado pelos órgãos competentes; 
e) Em termos instrumentais, quanto ao conteúdo jurídico, no ordenamento brasileiro, da progressividade tributária:

i. Que a progressividade promove a ideia de igualdade através da tributação e, especialmente, promove o dever de reduzir desigualdades;

ii. Que a progressividade não é demandada pela capacidade contributiva nem ofende a capacidade contributiva, mas é externa a ela, derivando de outros fundamentos constitucionais;

iii. Que a progressividade, decorrendo de outros fundamentos, não necessita estar prevista expressamente na regra de outorga de competência;

iv. Que não há ordem constitucional expressa, judicialmente controlável, de progressividade do sistema tributário ou de tributos isolados, apesar do evidente direcionamento contrário a uma incidência regressiva;

f) Que a seletividade, para redução da regressividade dos tributos indiretos, é aspecto passível de controle judicial, embora por meios concentrados e não individuais;

g) Que, embora o desuso de tributos com maior potencial redistributivo represente um óbice à redução de desigualdades, é impossível o controle judicial que determine a maior exploração dessas bases econômicas;

h) Que, diante da regressividade do IPTU, rejeitam-se considerações abstratas sobre os efeitos econômicos de eventual atualização da base imponível;

i) Que a regressividade da não correção da base de cálculo do IRPF pode apenas ser suscitada em deliberação político-legislativa;

j) Que a igualdade na tributação deve também considerar o objetivo de reduzir desigualdades a partir do tributo, atingindo conclusões práticas, como a validade de limitações de acesso ao SIMPLES Nacional;

k) Em termos de federalismo fiscal, que o Fundo de Participação dos Municípios merece controle judicial por não estar estruturado - contrariando disposição constitucional - para promover desconcentração, seja em seus critérios formativos, seja no congelamento de índices de distribuição;

1) Que, quanto às transferências do SUS, do FUNDEB e do BNDES, atinge-se apenas, quanto aos primeiros, reforço argumentativo às ações que visam a interferência do Poder Judiciário para fixação de exigência patamares mínimos de qualidade e, quanto ao terceiro, encontra-se tão somente razão para debate legislativo; 
m) Que, quanto à regra de não-vinculação, são equivocadas as ideias de sua irrelevância ou impertinência;

n) Em termos participativos, quanto ao uso de gastos tributários:

i. Que a característica de obscuridade e regressividade desses gastos tributários impõe maior esforço nos espaços de controle, autorizando atuação contundente dos órgãos respectivos e demandando até mesmo controle judicial nos casos de submissão de propostas orçamentárias que deixem de apresentar com clareza os efeitos econômicos (quanto, quem arca) e distributivos (quem se beneficia) dos gastos tributários;

ii. Que o falho controle de efetividade e eficiência desses gastos tributários demanda o uso da perspectiva de controle judicial visando desbloqueio institucional para, quebrando a inércia, ordenar a feitura de relatórios de avaliação, construção de meios de interlocução entre órgãos de arrecadação e de promoção material de políticas, incluindo a sociedade civil;

iii. Que é possível exigir que a aprovação de gastos tributários se submeta aos mesmos ritos de aprovação (processo legislativo) dos gastos diretos;

iv. Que o foco nas características regressivas, obscuras e pouco democráticas dos gastos tributários indica a rejeição da Ação Direta de Inconstitucionalidade que busca o aumento, pela via judicial, dos valores de dedução de despesas com educação no IRPF;

o) Que impõe-se sejam reconhecidas as formas usuais de endividamento oculto, dandolhes idêntico tratamento àquele outorgado ao endividamento confesso;

p) Que é constitucionalmente inviável a regra de unanimidade do CONFAZ para aprovação de isenções relacionadas ao ICMS;

q) Que é constitucionalmente inadequada a interdição de deliberação, no Projeto de Lei Orçamentária, a respeito do serviço da dívida.

Estas conclusões jurídicas são possíveis apenas uma vez aceitas as premissas iniciais e investigado empiricamente o papel de (des)concentração que os instrumentos financeiros selecionados vêm desempenhando no sistema nacional.

Para retomar ao posto na introdução: esta tese pretendeu ocupar, no plano jurídico, um espaço que se vislumbrou aberto conjugando, de um lado, a centralização dos debates 
sobre o objetivo fundamental de redução de desigualdades e, de outro, a evolução da compreensão do papel da atividade financeira do Estado que, como se argumentou, pode e deve se ocupar da busca dos objetivos constitucionais. Tudo de forma a ofertar uma ferramenta de análise, uma lente com a qual analisar diversos debates jurídicos hodiernos. 


\section{REFERÊNCIAS BIBLIOGRÁFICAS}

ABRAHAM, Marcus. Sanções contra a irresponsabilidade fiscal. Jota, 06 abr. 2017. Coluna Fiscal. Disponível em: https://www.jota.info/opiniao-e-analise/colunas/colunafiscal/sancoes-contra-a-irresponsabilidade-fiscal-06042017 Acesso em 24 mar. 2018.

. Curso de direito financeiro brasileiro. 3. ed. Rio de Janeiro: Forense, 2015.

.; SANTOS, Carlos Alberto C.; FRANCO, Fernando Raposo. As renúncias fiscais: um panorama introdutório. Revista Fórum de Direito Financeiro e Econômico, ano 05, n. 09, mar-ago 2016.

ABRÚCIO, Fernando Luiz; FRANZESE, Cibele; SANO, Hironobu. Trajetória recente da cooperação e coordenação no federalismo brasileiro: avanços e desafios. In: CARDOSO Jr., José Celso; e BERCOVICI, Gilberto (Orgs.). República, democracia e desenvolvimento: contribuições ao Estado brasileiro contemporâneo. Brasília: IPEA, 2013.

Os barões da federação: os governadores e a redemocratização brasileira. São Paulo: Hucitec / Departamento de Ciência Política, USP, 1998.

ACEMOGLU, Daron; ROBINSON, James A. The economic impact of colonialism. 2017. Disponível em: <https://voxeu.org/article/economic-impact-colonialism> Acesso em 02 abr. 2018.

; JOHNSON, Simon; ROBINSON, James A. Reversal of fortune: geography and institutions in the making of the modern world income distribution. The Quarterly Journal of Economics, v. 117, n. 04, nov 2002.

AFONSO DA SILVA, Virgílio. O judiciário e as políticas públicas: entre transformação social e obstáculo à realização dos direitos sociais. In: SOUZA NETO, Cláudio Pereira de; SARMENTO, Daniel (Orgs.). Direitos sociais: fundamentação, judicialização e direitos sociais em espécies. Rio de Janeiro: Lumen Juris, 2008.

AFONSO, José Roberto Rodrigues. Federalismo Fiscal brasileiro: uma visão atualizada. Caderno virtual IDP, v. 01, n. 34, 2016.

Imposto de renda e distribuição de renda e riqueza: as estatísticas fiscais e um debate premente no Brasil. Revista da Receita Federal: estudos tributários e aduaneiros, Brasília, v.01, n.01, ago/dez 2014.

IRPF e desigualdade em debate no Brasil: o já revelado e o por revelar. FGV IBRE, Texto para Discussão n. 42, de ago-2014.

- Tributação sobre o patrimônio no Brasil. Apresentação elaborada para ao Seminário Fundamentos Jurídicos do IPTU (IDP \& Prefeitura de Salvador). Salvador, 2014. Disponível em: http://portalibre.fgv.br/lumis/portal/file/fileDownload.jsp?fileId=8A7C82C5463DB403014 66207443C6730> Acesso em 12 fev. 2018.

- (Coord.); SILVEIRA, Ricardo Figueiró; CARVALHO, Célia Maria Silva; KLINTOWITZ, Danielle; AZEVEDO, Felipe de. A renúncia tributária do ICMS no Brasil. Banco Interamericano de Desenvolvimento. Documento para discussão IDB-DP-327. 2014. 
.; CASTRO, Kleber Pacheco de. Carga tributaria en Brasil: redimensionada y repensada. Revista de Administración Tributaria CIAT (Centro Interamericano de Administraciones Tributarias), n. 40, mar. 2016.

.; CASTRO, Kleber Toledo de; SANTOS, Fabrício Marques. Potencial e exploração do imposto patrimonial imobiliário no Brasil: uma análise do IPTU a partir da teoria dos conjuntos fuzzy. Lincoln Institute of Land Policty, Working Paper WP16JA1PO, 2016.

.; RIBEIRO, Leonardo. Securitizar créditos tributários, um primeiro passo. Boletim Conjuntura Econômica, jan. 2018.

.; SOARES, Julia Morais; CASTRO, Kleber Pacheco de. Avaliação da estrutura e do desempenho do sistema tributário brasileiro: livro branco da tributação brasileira. Banco Interamericano de Desenvolvimento, Documento para discussão \#IDB-DP-265, 2013.

3, 2009-2010.

FPE: rateio sem critério. Observatório da jurisdição constitucional, Brasília, ano

AHMAD, Ehtisham; SEARLE, Bob. On the implementation of transfers to subnational governments. In: AHMAD, Ehtisham; BROSIO, Giorgio. Handbook of fiscal federalism. Cheltenham: Edward Elgar Publishing, 2006.

ALENCAR, André Amorim; GOBETTI, Sérgio Wulff. Justiça fiscal na federação brasileira: uma análise do sistema de transferências intergovernamentais entre $2000 e$ 2007. Brasília: ESAF, 2008. Monografia premiada com o primeiro lugar no XIII Prêmio Tesouro Nacional, 2008.

ALESINA, Alberto; RODRIK, Dani. Distributive politics and economic growth. Quarterly Journal of Economics, v. 109, n. 02, mai.1994.

ALEXY, Robert. Teoria dos direitos fundamentais. Tradução da 5. edição alemã, por Virgílio Afonso da Silva. São Paulo: Malheiros, 2008.

ALMEIDA, Aloísio Flávio Ferreira de; ALMEIDA, Carlos Otávio Ferreira de. O equilíbrio federativo como desafio ao novo formato do Fundo de Participação dos Estados (FPE). Revista Fórum de Direito Financeiro e Econômico, ano 2, n. 2, set. 2012-fev. 2013.

.; PAES, Nelson Leitão. The influence of interest on net equity and interest rates on tax neutrality - a case study of the Brazilian corporate taxation. EconomiA, v. 14, Issues 34, 2013.Disponível em: <http://www.sciencedirect.com/science/article/pii/S1517758013000131> Acesso em 16 jan. 2018.

ALMEIDA, Rodolfo; MARIANI, Daniel; OSTETTI, Vitória. O imposto sobre absorventes no Brasil e no mundo. Nexo Jornal, 05 dez. 2016, Disponível em: https://www.nexojornal.com.br/grafico/2016/12/05/O-imposto-sobre-absorventes-noBrasil-e-no-mundo. Acesso em: 23 mar. 2018.

ALMEIDA, Saulo Felipe Caldeira de. Campeões nacionais: o papel do BNDES e a atuação do Sistema Brasileiro de Defesa da Concorrência. Dissertação (Mestrado). Universidade Presbiteriana Mackenzie. São Paulo, 2012. 
ALMENDRAL, Violeta Ruiz. A myopic economic constitution? Controlling the debt and the deficit without fiscal integration. Revista Fórum de Direito Financeiro e Econômico, ano 05, n. 08, set-fev 2016.

ALVAREDO, Facundo; CHANCEL, Lucas; PIKETTY, Thomas; SAEZ, Emmanuel; ZUCMAN, Gabriel (Coords.). World Inequality Report 2018. World Inequality Lab, 2018.

AMARANTE, Verónica; JIMÉNEZ, Juan Pablo. Desigualdad, concentración y altas rentas en América Latina. In: JIMÉNEZ, Juan Pablo (Ed.). Desigualdad, concentración del ingreso y tributación sobre las altas rentas en América Latina. Libros de la CEPAL, $\mathrm{N}^{\circ} 134$ (LC/G.2638-P), Santiago: CEPAL, 2015.

AMARO, Luciano. Direito Tributário Brasileiro. 16. ed. São Paulo: Editora Saraiva, 2010. Direito Tributário Brasileiro. 13. ed. rev. São Paulo: Saraiva, 2007.

ANDERSON, George. Una introducción al federalismo. Trad. Isabel Vericat y Celorio Morayta. Madrid: Marcial Pons, 2008.

ANDRADE, Cesar Augusto Seijas de. Orçamento deficitário. In: CONTI, José Maurício; SCAFF, Fernando Facury (Org.). Orçamentos públicos e direito financeiro. São Paulo: RT, 2011.

ANDRADE, Jucilaine A. Reforma tributária no Brasil e seus impactos na redução da desigualdade: uma análise das propostas de emenda à Constituição sob a perspectiva da justiça fiscal. Revista Eletrônica Gestão \& Sociedade, v.9, n.22, jan-abr. 2015.

ANGELIS, Ângelo de. O imposto sobre o valor agregado e o ICMS no estado de São Paulo - 1988 a 2013 - 25 anos. Dissertação (Mestrado). Universidade Estadual de Campinas. Campinas, 2016.

A substituição tributária no ICMS - problemas e possíveis soluções. Primeiro prêmio no concurso de monografias da Federação Nacional dos Fiscos Estaduais. 2012. Disponível em: <http://www.joserobertoafonso.com.br/attachment/20410> Acesso em 04 fev. 2018.

APPY, Bernard. Precisamos rever o Simples. O Estado de São Paulo, São Paulo, 07 mar. 2017. Opinião. Disponível em: http://economia.estadao.com.br/noticias/geral,precisamosrever-o-simples, 70001689162. Acesso em 24 fev. 2018.

Distorções do sistema tributário brasileiro. Apresentação. 2016. Disponível em: <http://www.joserobertoafonso.com.br/distorcoes-sistema-tributario-appy/> Acesso em 24 fev. 2018.

Por que o sistema tributário brasileiro precisa ser reformado. Revista Interesse Nacional, ano 8, n. 31, out-dez 2015.

O SIMPLES é bom? O Estado de São Paulo, São Paulo, 02 mar. 2015. Opinião. Disponível em: http://economia.estadao.com.br/noticias/geral,o-simples-e-bom-imp,1642394. Acesso em 24 fev. 2018.

Porque o SIMPLES precisa ser modificado. Mimeo. Disponível em:

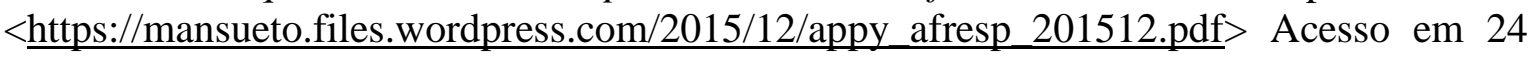
fev. 2018. 
ARAÚJO, Bruno César; DE NEGRI, João Alberto. O tamanho do BNDES e resposta à crise: uma comparação internacional. Radar IPEA n. 51, jun. 2017.

ARAUJO, Luiz Alberto David; NUNES JÚNIOR, Vidal Serrano. Curso de direito constitucional. 21. ed., rev. e atual. São Paulo: Editora Verbatim, 2017.

Controle concentrado da constitucionalidade e segurança jurídica no sistema brasileiro. In: MAUÉS, Antonio G. Moreira; SCAFF, Fernando Facury; BRITO FILHO, José Claudio Monteiro de (Coords.). Direitos fundamentais e relações sociais no mundo contemporâneo. Curitiba: Juruá, 2005.

ARAÚJO, Luiz. É possível diminuir as desigualdades entre os municípios brasileiros por meio de uma política de fundos na educação? Fineduca - Revista de Financiamento da Educação, v.3, nº12, 2013.

O federalismo, os fundos na educação e a diminuição das desigualdades. Revista Retratos da Escola, v. 6, n. 10, jan-jun. 2012.

ARAÚJO, Raimundo Luiz Silva. Limites e possibilidades da redução das desigualdades territoriais por meio do financiamento da educação básica. Tese (Doutorado). Universidade de São Paulo. São Paulo, 2013.

ARAÚJO, Victor Leonardo de; CINTRA, Marcos Antonio Macedo. O papel dos bancos públicos federais na economia brasileira. IPEA, Texto para Discussão IPEA n. 1604, abr. 2011.

ARAÚJO, Victor. Federalismo, centralização e diferenças regionais: o padrão de desigualdade das políticas não reguladas do Brasil pós-1988. Revista Perspectivas em Políticas Públicas, Belo Horizonte, v. VIII, n. 15, jan-jun 2015.

ARENA DE MESA, Alberto. Sostenibilidad fiscal y reformas tributarias en América Latina. CEPAL/BID: Santiago, 2016.

ARIZA, Libardo José. The economic and social rights of prisoners and constitutional court intervention in the penintentiary system in Colombia. In : MALDONADO, Daniel Bonilla (Ed.). Constitutionalism of the global south : the activist tribunals of India, South Africa, and Colombia. Cambridge Universty Press: New York, 2013.

ARRETCHE, Marta. Democracia e redução da desigualdade econômica no Brasil: a inclusão dos outsiders. Revista Brasileira de Ciências Sociais, v. 33, n. 96, 2018.

A metade cheia ou a metade vazia do copo? In: Cada vez mais desigual? Le Monde Diplomatique Brasil - Centro de Estudos da Metrópole - Oxfam Brasil, abr. 2016.

. (Org.). Trajetória das desigualdades: como o Brasil mudou nos últimos cinquenta anos. São Paulo: Editora UNESP; CEM, 2015

. Federalismo e igualdade territorial: uma contradição em termos? DADOS Revista de Ciências Sociais, Rio de Janeiro, v. 53, n. 3, 2010.

.; RODDEN, Jonathan. Política distributiva na federação: estratégias eleitorais, barganhas legislativas e coalizões de governo. DADOS - Revista de Ciências Sociais, Rio de Janeiro, v. 47, n. 3, 2004.

ASSIS, Luiz Gustavo Bambini de. Processo legislativo e orçamento público: função de controle do Parlamento. São Paulo: Saraiva, 2012. 
ASSUNÇÃO, Matheus Carneiro. $O$ princípio da transparência no direito financeiro brasileiro. Tese (Doutorado). Universidade de São Paulo. São Paulo, 2017.

Repartição das receitas tributárias no federalismo fiscal brasileiro: os critérios de rateio dos fundos de participação. Dissertação (Mestrado). São Paulo: Universidade de São Paulo, 2013.

ATALIBA, Geraldo. IPTU - progressividade. Revista de Direito Tributário, São Paulo, v. 15, n. 56, abr-jun 1991.

ATKINSON, Anthony B. Desigualdade: o que pode ser feito? São Paulo: LeYa, 2015.

.; STIGLITZ, Joseph E. The Design of Tax Structure: Direct Versus Indirect Taxation. Journal of Public Economics, 6(1-2): 55-75, 1976.

ATTAS, Daniel. A transgenerational difference principle. In: GOSSERIES, Axel; MEYER, Lukas H. (Coord.). Intergenerational justice. New York: Oxford University Press, 2009.

ÁVILA, Ana Paula Oliveira; MIRANDA, Paula Mandagará. Supremo Tribunal Federal: ativismo ou self-restraint na efetivação de direitos sociais? Quaestio Juris, v. 10, n. 01, 2017 ÁVILA, Humberto. Ciência do Direito Tributário e discussão crítica. Revista Direito Tributário Atual, São Paulo, IBDT e Dialética, n. 32, 2014.

Teoria da igualdade tributária. 2. ed. São Paulo: Malheiros Editores, 2009.

ICMS: Substituição tributária no Estado de São Paulo; base de cálculo; pauta fiscal; competência legislativa estadual para devolver a diferença constante entre o preço usualmente praticado e o preço constante na pauta; exame de constitucionalidade. Revista Dialética de Direito Tributário, São Paulo, n. 124, jan. 2006.

AVILA, Róber Iturriet e CONCEIÇÃO, João Santos. Injustiça fiscal à brasileira: eis o gráfico da desigualdade. Publicado em 19 set. 2016, Carta Capital. Disponível em: https://www.cartacapital.com.br/blogs/outras-palavras/injustica-fiscal-a-brasileira-eis-ografico-da-desigualdade. Acesso em 13 jan. 2018.

AVI-YONAH, Reuven S. Os três objetivos da tributação. Trad. Luís Flávio Neto. Revista Direito Tributário Atual, São Paulo, n. 22, p. XX, 2008.

.; MARGALIOTH, Yoram. Taxation in developing countries : some recent support and challenges to the conventional view. Virginia Tax Review 27, n. 1, 2007.

. Why tax the rich? Efficiency, equity, and progressive taxation. The Yale Law Journal, v. 111, n. 06, fev. 2002.

Globalization, tax competition, and the fiscal crisis of the welfare state. Harvard Law Review, v. 113, n. 07, mai. 2000.

BAIÃO, Alexandre Lima; CUNHA, Armando Santos Moreira da; SOUZA, Flavio Sérgio Rezende Nunes de. Papel das transferências intergovernamentais na equalização fiscal dos municípios brasileiros. Revista do Serviço Público, v. 68, n. 3, 2017.

BALEEIRO, Aliomar. Uma introdução à ciência das finanças. 16. ed. rev. e atual. Dejalma de Campos. Rio de Janeiro: Forense, 2004.

BANCO MUNDIAL. Um ajuste justo: análise da eficiência e equidade do gasto público no Brasil. Banco Mundial: nov. 2017. 
BANDEIRA DE MELLO, Celso Antônio. Conteúdo jurídico do princípio da igualdade. 3. ed., atual. São Paulo: Malheiros Editores, 1999.

BANKMAN, Joseph; GRIFFITH, Thomas. Social welfare and the rate structure: a new look at progressive taxation. 75 California Law Review, v. 75, n. 06, p. 1905-1967, 1987.

BARATTO, Gedalva; MACEDO, Mariano de Mattos. Regime tributário do ICMS nas transações interestaduais - harmonização tributária ou autonomia estadual? Revista Paranaense de Desenvolvimento, Curitiba, n. 113, jul/dez. 2007, 2007.

BARBOSA, Nelson. Carga tributária, dividendos e amnésia seletiva. Blog do IBRE. 13 set. 2017. Disponível em: <http://blogdoibre.fgv.br/posts/carga-tributaria-dividendos-eamnesia-seletiva> Acesso em 24 fev. 2018.

. O governo e a dona de casa. Folha de São Paulo, 27 abr. 2018

BARBOZA, Estefânia Maria de Queiroz; KOZICKI, Kátia. Judicialização da política e controle judicial de políticas públicas. Revista Direito GV, v. 08, n. 01, jan- jun-2012.

BARREIX, Alberto; BENÍTEZ, Juan Carlos; PECHO, Miguel. Revisiting personal income tax in Latin America: Evolution and impact. OECD Development Centre, Working paper n. 338, mar-2017.

BARRETO, Aires F. Progressividade (conteúdo, sentido, limites de sua aplicação ao IPTU). In TÔRRES, Heleno Taveira (coord.). Tratado de Direito Constitucional Tributário: Estudos em homenagem a Paulo de Barros Carvalho. São Paulo: Saraiva, 2005.

BARRETO, TAKANO. Os desafios do planejamento tributário internacional na era pósBEPS. IBET, 2016. Disponível em: http://www.ibet.com.br/wpcontent/uploads/2017/09/BEPS.pdf. Acesso em 11 abr. 2018.

BARROS, Alexandre Rands. Desigualdades regionais no Brasil: naturezas, causas, origens e soluções. Rio de Janeiro: Elsevier, 2011.

BARROS, Gabriel Leal de. Atualiação tributária: a influência e impacto das renúncias fiscais. IFI - Instituição Fiscal Independente. Nota Técnica n. 07, set. 2017.

; AFONSO, José Roberto. Nota Técnica: Fundo de Participação dos Estados: PIB ou renda? Texto para Discussão FGV-IBRE s/n., abr. 2013.

BARROS, Ricardo Paes de; HENRIQUES, Ricardo; MENDONÇA, Rosane. Desigualdade e Pobreza no Brasil: retrato de uma estabilidade inaceitável. Revista Brasileira de Ciências Sociais, v. 15, n. 42, 2000.BARROSO, Luís Roberto. Judicialização, ativismo judicial e legitimidade democrática. (Syn)Thesis, v. 05, n, 01, 2012.

BARROSO, Rafael Mendes Cunha. Federalismo fiscal no Brasil: o impacto das transferências orçamentárias na desconcentração de receitas entre as esferas de governo. Revista Controle - doutrinas e artigos, v. 11, n. 01, 2013.

BARTELS, Larry M. Political inequality in affluent democracies: the social welfare deficit. Vanderbilt University Working Paper n. 05/2017, mar-2017.

BASSI, Camillo de Moraes; ARAÚJO, Herton Ellery; CODES, Ana. Fundeb e VAA Mínimo Nacional: critérios alternativos e reflexos sobre a complementação da União. Nota Técnica IPEA DISOC n. 44, nov.2017. 
BASTAGLI, Francesca; COADY, David; GUPTA, Sanjeev. Income inequality and fiscal policy. IMF Staff Discussion Note n. SDN/12/08, sep.2012.

BATISTA JÚNIOR, Onofre Alves. $O$ outro Leviatã e a corrida ao fundo do poço. São Paulo: Almedina, 2015.

; OLIVEIRA, Ludmila Mara Monteiro de; MAGALHÃES, Tarcísio Diniz. Liberalismo, desigualdade e Direito Tributário. Revista Brasileira de Estudos Políticos, n. 110, jan-jun 2015.

BECHO, Renato Lopes; ARAÚJO, Guilherme Peloso. Segurança jurídica em matéria tributária. In: MARTINS, Ives Gandra da Silva. (Coord.). Segurança jurídica em matéria tributária. Porto Alegre: Magister, 2016.

BELLUZZO, Luiz Gonzaga. O capital e suas metamorfoses. São Paulo: Editora UNESP, 2013.

BENAYON, Adriano; REZENDE, Pedro Antonio Dourado de. Anatomia de uma fraude à Constituição. Disponível em: <http://www.cic.unb.br/ rezende/trabs/fraudeac_files/fraudeac.pdf> Acesso em 10 mar. 2018.

BERAMENDI, Pablo; REHM, Philipp. Who gives, who gains? Progressivity and preferences. Comparative political studies, v. 49, nº 04, mar. 2016.

BERCOVICI, Gilberto. Estado, planejamento e direito público no Brasil contemporâneo. In: CARDOSO JR., José Celso; SANTOS, Eugênio A. Vilela dos. (Orgs.). PPA 2012-2015: experimentalismo institucional e resistência burocrática. Brasília: IPEA, 2015.

BERCOVICI, Gilberto. Política econômica e direito econômico. Revista Fórum de Direito Financeiro e Econômico, v. 1, 2012.

BERCOVICI, Gilberto. Federalismo cooperativo e igualação das condições sociais de vida. Revista de Direito da Associação dos Procuradores do Novo Estado do Rio de Janeiro, v. XIX. Rio de Janeiro: Lumen Juris: APERJ, 2008.

. Federalismo e Desenvolvimento Regional no Brasil. In: Luís Eduardo Schoueri. (Org.). Direito Tributário: Homenagem a Paulo de Barros Carvalho. São Paulo: Quartier Latin, 2008.

Planejamento e políticas públicas: por uma nova compreensão do papel do Estado. In: BUCCI, Maria Paula Dallari (Org.). Políticas públicas: reflexões sobre o conceito jurídico. São Paulo: Saraiva, 2006.

.; e MASSONETTO, Luís Fernando. A constituição dirigente invertida: a blindagem da constituição financeira e a agonia da constituição econômica. Boletim de Ciências Econômicas XLIX. Coimbra: Universidade de Coimbra, 2006.

. Constituição econômica e desenvolvimento: uma leitura a partir da Constituição de 1988. São Paulo: Malheiros Editores, 2005.

Constituição e política: uma relação difícil. Lua nova, n. 61, 2004.

. Desigualdades Regionais, Estado e Constituição. São Paulo: Max Limonad, 2003.

A descentralização de políticas sociais e o federalismo cooperativo brasileiro.

Revista de Direito Sanitário, v. 3, n.1, mar. 2002. 
. Constituição e Superação das Desigualdades Regionais. In GRAU, Eros Roberto \& GUERRA Filho, Willis Santiago (orgs.), Direito Constitucional - Estudos em Homenagem a Paulo Bonavides. São Paulo, Malheiros, 2001.

BEREIJO, Álvaro Rodríguez. El significado jurídico del deber constitucional de pagar impuestos. Revista de direito tributário - Malheiros, São Paulo, n. 113, 2011.

BIM, Eduardo Fortunato. A autocontenção judicial no direito administrativo participativo: o caso das audiências públicas ambientais. Revista Digital de Direito Administrativo, v. 02, n. 01, 2015.

Divergências científicas e metodológias no Direito Ambiental e autocontenção judicial. Direito Público, n. 46, jul-ago 2012.

BIRD, Richard M. Subnational taxation in developing countries: a review of the literature. World Bank Policy Research Working Paper n. 5450, out-2010.

.; ZOLT, Eric M. Redistribution via taxation: the limited role of the personal income tax in developing countries. UCLA Law Review, v. 52,2005

BOADWAY, Robin. Intergovernmental redistributive transfers: efficiency and equity. In: AHMAD, Ehtisham; BROSIO, Giorgio. Handbook of fiscal federalism. Cheltenham: Edward Elgar Publishing, 2006.

.; SHAH, Anwar. Fiscal federalism: principles and practice of multiorder governance. Nova York: Cambridge University Press, 2009.

.; ROBERTS, Sandra; SHAH, Anwar. Fiscal federalism dimensions of tax reform in developing countries. World Bank Policy Research Working Paper n. 1385 nov. 1994.

BONAVIDES, Paulo. Curso de Direito Constitucional. 12. ed., rev. e atual. São Paulo: Malheiros Editores, 2002.

. A Constituição aberta - temas políticos e constitucionais da atualidade, com ênfase no federalismo das regiões. 2. ed. São Paulo: Malheiros, 1996.

BORGES, José Souto Maior. Introdução ao direito financeiro, $2^{\mathrm{a}}$ ed. São Paulo: Max Limonad, 1998.

BÖS, Dieter. Earmarked taxation: welfare versus political support. CESifo Working Paper n. 207, nov-1999.

BOTTALLO, Eduardo Domingos. IPI - princípios e estrutura. São Paulo: Dialética, 2009.

BOURGUIGNON, François. World changes in inequality: na overview of facts, causes, consequences and policies. BIS Working Papers n. 654, ago. 2017.

BOUSHEY, Heather; DELONG, J. Bradford; STEINBAUM, Marshall (eds.). After Piketty: the agenda for economics and inequality. Cambridge, Massachusstes, Londong, England: Harvard University Press, 2017.

BRASIL. Balanço Geral da União 2015,. Disponível em: <http://www.tesouro.fazenda.gov.br/documents/10180/337275/Balan\%C3\%A7oGeral+da+Uni\%C3\%A3o+2015/2a07224d-b264-48d7-bbe7-a12de5706b4c> Acesso em 08 ago. 2016. 
BRASIL. Relatório indica que Brasil saiu do Mapa Mundial da Fome em 2014. 16 set. 2014. Disponível em: <http://www.brasil.gov.br/governo/2014/09/relatorio-indica-que-brasilsaiu-do-mapa-mundial-da-fome-em-2014> Acesso em 04 abr. 2018.

BRASIL. Presidência da República. Observatório da Equidade. Indicadores de Equidade do Sistema Tributário Nacional. Brasília: Presidência da República, Observatório da Equidade, 2009.

BREGMAN, Daniel. Reforma Tributária e Mudança no Critério de Distribuição da CotaParte do ICMS: compatibilidade e impacto nos orçamentos municipais. Brasília: ESAF, 2010. Monografia inscrita no XV Prêmio Tesouro Nacional - 2010: Homenagem a Joaquim Nabuco. Tópicos Especiais de Finanças Públicas. Rio de Janeiro (RJ).

BREYNER, Frederico Menezes. Benefícios fiscais e regressividade tributária. In: DERZI, Misabel Abreu Machado; MELO, João Paulo Fanucchi de Almeida (Coord.). Justiça Fiscal. Belo Horizonte: Del Rey, 2016.

BROOKS, John. Fiscal Federalism as Risk-Sharing: The Insurance Role of Redistributive Taxation. Tax Law Review, v. 68, p. 89-142, 2014. Disponível em: <http://ssrn.com/abstract=2456420> Acesso em 01 jul. 2015.

BRÜLHART, Marius; DEUPERTUIS, Didier; MOREAU, Elodie. Inheritance flows in Switzerland, 1911-2011. jan-2017. CEPR Discussion Paper n. DP11768. Disponível em: <SSRN: https://ssrn.com/abstract=2900185> Acesso em 19 fev. 2018.

BUCCI, Maria Paula Dallari. Fundamentos para uma teoria jurídica das políticas públicas. São Paulo: Saraiva, 2013.

BUFFON, Marciano; ANSELMIN, Priscila. O imposto mundial sobre o capital: da sua relevância sócio-jurídica para a redução de desigualdade de renda e patrimônio, a partir de Piketty. Revista de Direito Internacional, Econômico e Tributário, v. 12, n. 1, jan-jun 2017.

BUISSA, Leonardo; BEVILACQUA, Lucas. Seletividade, justiça fiscal e neutralidade concorrencial: o ICMS sobre energia elétrica nos tribunais superiores. Revista Interesse Público, ano 19, n. 104, jul-ago 2017.

BURMAN, Len; TODER, Eric; BERGER, Daniel; ROHALY, Jeffrey. Economic and distributional effects of tax expenditure limits. In: AUERBACH, Alan J.; SMETTERS, Kent (Eds.). The Economics of tax policy. New York : Oxford University Press, 2017.

BURMAN, Leonard. Taxes and inequality. Tax Law Review, v. 66, 2013.

BUSTAMANTE, Thomas da Rosa de; DUTRA, Franklin Vinícius Marques. A tributação sobre heranças e doações e sua justificação moral: parâmetros introdutórios para a sua valoração e para melhoramentos no sistema jurídico. In: DERZI, Misabel Abreu Machado; MELO, João Paulo Fanucchi de Almeida (Coords.). Justiça Fiscal. Belo Horizonte: Del Rey, 2016.

CABALLERO, Jackeline Saravia; FERNÁNDEZ, Andréa Rodríguez. Los desplazados forzados internos em el Estado de Cosas Inconstitucional, un assunto pendiente. Revista Prolegómenos - Derechos y Valores, v. 18, n. 35, jun. 2015.

CAIDEN, Naomi e WILDAVSKY, Aaron. Planning and Budgeting in Poor Countries. London: Transaction Publishers, 2003. 
CALABRESI, Guido; BOBBIT, Philip. Tragic choices: the conflicts society confronts in the allocation of tragically scarce resources. New York: W. W. Norton \& Company, 1978.

CALDAS FURTADO, José de Ribamar. O problema da vinculação de recursos orçamentários. Revista do TCU, n. 111, jan-abr. 2008.

CALIENDO, Paulo. Clássicos do Direito Tributário. Porto Alegre: Editora Livraria do Advogado, 2016.

Direito tributário: três modos de pensar a tributação: elementos para uma teoria sistemática do direito tributário. Porto Alegre: Livraria do Advogado Editora, 2009.

Princípio da neutralidade fiscal. Conceito e aplicação. In: PIRES, Adilson Rodrigues; TÔRRES, Heleno Taveira. Princípios de direito financeiro e tributário Estudos em homenagem ao Professor Ricardo Lobo Torres. Rio de Janeiro: Renovar, 2006.

CALLADO, Marcelo. Federalismo fiscal: os efeitos dos Fundos de Participação dos Estados (FPE) e dos Municípios (FPM) na distribuição de renda inter-regional e interpessoal no Nordeste brasileiro. Mimeo. Disponível em: <http://www.ric.ufc.br/evento1/marcelo_callado.PDF> Acesso em 04 mar. 2018.

CAMIC, Susannah. Earmarking: The Potential Benefits. Pittsburgh Tax Review, v. 4:55, 2006.

CAMPILONGO, Celso Fernandes. Direito e democracia. São Paulo: Max Limonad, 1997.

CAMPOS, Carlos Alexandre de Azevedo. Da inconstitucionalidade por omissão ao "Estado de Coisas Inconstitucional". Tese (Doutorado). Universidade do Estado do Rio de Janeiro. Rio de Janeiro, 2015.

CANOTILHO, José Joaquim Gomes. Direito Constitucional e Teoria da Constituição. 3. ed. Coimbra: Almedina, 2000.

CARBONAR, Alberto F. T. S.; AMPESSAN, Thomas. ICMS sobre fornecimento de energia elétrica e serviços de telecomunicação. Disponível em: <https://www.jota.info/opiniao-eanalise/artigos/icms-sobre-fornecimento-de-energia-eletrica-e-servicos-detelecomunicacao-01012018> Acesso em 03 fev. 2018.

CARDOSO JR., José Celso. Estado, planejamento, gestão e desenvolvimento: balanço da experiência brasileira e desafios no século XXI. CEPAL, 2014.

CARDOSO, Alessandro Mendes. O dever fundamental de recolher tributos no estado democrático de direito. Porto Alegre: Livraria do Advogado, 2014.

CARNEIRO, Mariana. Governo não sabe se metade dos programas de subsídio dão resultado. Folha de São Paulo, 08 jan. 2018. Disponível em: http://www1.folha.uol.com.br/mercado/2018/01/1948680-governo-nao-controlaefetividade-53-dos-subsidios-de-renuncia-de-impostos.shtml. Acesso em 13 jan. 2018.

CARRAZZA, Roque Antonio. ICMS. 12. ed. São Paulo: Malheiros, 2007. p. 400. No sentido oposto, dentre vários: MACHADO, Hugo de Brito. Curso de direito tributário. 29.ed. São Paulo: Malheiros, 2008.

CARTER, Alan; MATTHEWS, Stephen. How tax can reduce inequality. OECD Observer. Disponível em 
http://oecdobserver.org/news/fullstory.php/aid/3782/How_tax_can_reduce_inequality.html > Acesso em 06 abr. 2018.

CARVALHO JR., Pedro H. B. Property tax performance in São Paulo. Journal of Property Tax Assessment \& Administration, Volume 11, Issue 2. 2014.

As discussões sobre a regulamentação do Imposto sobre Grandes Fortunas: a situação no Brasil e a experiência internacional. Nota Técnica. Brasília: IPEA, 2011.

Aspectos distributivos do IPTU e do patrimônio imobiliário das famílias brasileiras. In: CASTRO, Jorge Abrahão de; SANTOS, Cláudio Hamilton Matos dos; RIBEIRO, José Aparecido Carlos (Orgs.). Tributação e equidade no Brasil: um registro da reflexão do IPEA no biênio 2008-2009. Brasília: IPEA, 2010.

Aspectos distributivos do IPTU e do patrimônio imobiliário das famílias brasileiras. Texto para Discussão IPEA n. 1417, ago. 2009.

CARVALHO, André Castro. Direito da infraestrutura: perspectiva pública. São Paulo: Quartier Latin, 2014.

Mecanismos para a otimização do federalismo fiscal brasileiro. In: CONTI, José Maurício; SCAFF, Fernando Facury; BRAGA, Carlos Eduardo Faraco (Org.). Federalismo fiscal: questões contemporâneas. Florianópolis: Conceito, 2010.

Vinculação de receitas públicas e princípio da não afetação: usos e mitigações. Dissertação (Mestrado). Universidade de São Paulo. São Paulo, 2010.

CARVALHO, David Ferreira. O ciclo da economia brasileira e a Amazônia na dinâmica regional centro-periferia. Paper do NAEA n. 120, mai.1999. Disponível em: <http://www.naea.ufpa.br/naea/novosite/paper/268> Acesso em 29 nov. 2015.

CASHIN, Cheryl; SPARKES, Susan; BLOOM, Danielle. Earmarking for health: from theory to practice. World Health Organization, Health Financing Working Paper n. 5, 2017.

CASTILHO, Fábio Roberto Corrêa. Federalismo fiscal e repartição do ICMS: o critério do valor adicionado. 2014. Tese (Doutorado). São Paulo: Universidade de São Paulo, 2014.

CASTRO, Fábio Ávila de. Imposto de Renda da Pessoa Física: comparações internacionais, medidas de progressividade e redistribuição. Dissertação (Mestrado). Universidade de Brasília. Brasília, 2014.

.; BUGARIN, Maurício Soares. A progressividade do imposto de renda da pessoa física no Brasil. Estud. Econ., São Paulo, v. 47, n. 2, p. 259-293, jun. 2017. Disponível em http://www.scielo.br/scielo.php?script=sci_arttext\&pid=S0101-

$41612017000200259 \& \operatorname{lng}=$ pt\&nrm=iso $>$ Acesso em 12 jan. 2018.

CASTRO, José Roberto. Dilma disse que se arrependeu das desonerações: o que foi essa política e quais as críticas a ela. Nexo, 14 mar. 2017. Disponível em: $<$ https://www.nexojornal.com.br/expresso/2017/03/14/Dilma-disse-que-se-arrependeu-dasdesonera\%C3\%A7\%C3\%B5es-o-que-foi-essa-pol\%C3\%ADtica-e-quais-as-

cr\%C3\%ADticas-a-ela> Acesso em 24 fev. 2018.

CASTRO, Kleber Pacheco de; LIMA, Ana Carolina da Cruz. Avaliação da distribuição do FPM: uma aplicação da teoria dos conjuntos fuzzy para os municípios de Minas Gerais. Disponível em: 
<http://sisconev.com.br/Uploads/ENABER17/Trab015700354920170623_000000.pdf> Acesso em 05 mar. 2018.

CATÃO, Marcos André Vinhas. Novas perspectivas no princípio da não-afetação e destinação da receita tributária. In: PIRES, Adilson Rodrigues; TORRES, Heleno Taveira (org.). Princípios de direito financeiro e tributário. Rio de Janeiro: Renovar, 2006.

CATARINO, João Ricardo. Redistribuição tributária: Estado social e escolha individual. Coimbra, Almedina, 2008.

CAVAlCANTE, Luiz Rocardo. Políticas de desenvolvimento regional no Brasil: uma estimativa de custos. Texto para Discussão do Núcleo de Estudos e Pesquisas da Consultoria Legislativa do Senado Federal n. 154, set. 2014.

CENTRO INTERAMERICANO DE ADMINISTRACIONES TRIBUTARIAS - CIAT. Política Tributaria: ¿Qué Gravar, Cómo Gravar, Qué Objetivos debe Procurar el Sistema Tributario? Documento de Trabajo n. 3, outubro.2017.

CHULVI, Cristina Pauner. El deber constitucional de contribuir al sostenimiento de los gastos públicos. Madrid: Centro de Estudios Políticos y Constitucionales, 2001.

CIBILS, Vicente Fretes; TER-MINASSIAN, Teresa. Lackluster performance: local taxes in Latin America. In: CIBILS, Vicente Fretes; TER-MINASSIAN, Teresa (Eds.). Decentralizing revenue in Latin America: why and how. Washington: Inter-American Development Bank, 2015.

CITTADINO, Gisele. Judicialização da política, constitucionalismo democrático e separação de poderes. In: VIANNA. Luiz Werneck (Org.). A democracia e os três poderes no Brasil. Belo Horizonte: Editora UFMG, Rio de Janeiro: IUPERJ/FAPERJ, 2002.

CLARK, Gregory. The son also rises: surnames and the history of social mobility. Princeton: Princeton University Press, 2014.

CLÈVE, Clèmerson Merlin. Controle de constitucionalidade e democracia. In: MAUÉS, Antonio G. Moreira (Org.). Constituição e democracia. São Paulo: Max Limonad, 2001.

CNI; IBOPE. Pesquisa CNI-IBOPE, Edição Especial, jul-2013. Disponível em: $<$ http://www.ibope.com.br/pt-

br/noticias/Documents/CNI_IBOPE_edicao\%20especial_jul2013_web.pdf> Acesso em 12 fev. 2018.

CNI; PWC. A substituição tributária do ICMS no Brasil. 2011 Disponível em: <http://admin.cni.org.br/portal/data/pages/FF808081314EB36201314F2229716E7F.htm> Acesso em 04 fev. 2018.

COELHO, Danilo; DE NEGRI, João Alberto. Impacto do financiamento do BNDES sobre a produtividade das empresas: uma aplicação do efeito quantílico de tratamento. Mimeo. Disponível em: <http://www.anpec.org.br/encontro2010/inscricao/arquivos/00062cf725608576526071dfbbed02385cf.pdf> Acesso em 09 mar. 2018.

COÊLHO, Sacha Calmon Navarro. Introdução à teoria geral do Direito Tributário. Revista da Faculdade de Direito da Universidade Federal de Minas Gerais, v. 38, 2000.

COLE, Alan. Estate and inheritance taxes around the world. Tax Foundation Fiscal Fact $\mathrm{n}$. 458, mar. 2015. 
COLE, Wade M. Poor and powerless: economic and political inequality in cross-national perspective, 1981-2011. International Sociology, v. 33, n. 03, mai. 2018

COLISTETE, Renato Perim. O atraso em meio à riqueza: uma histórica econômica da educação primária em São Paulo, 1835 a 1920. Tese (Livre Docência). Universidade de São Paulo. São Paulo, 2016.

COLLIER, Paul. The bottom billion: why the poorest countries are failing and what can be done about it. NY: Oxford University Press, 2008.

COMPARATO, Fabio Konder. Brasil: verso e reverso constitucional. Cadernos IHU ideias, ano II, n. 197, 2013.

2010.

A afirmação histórica dos direitos humanos. 7. ed. rev. e atual. São Paulo: Saraiva,

Ensaio sobre o juízo de constitucionalidade de políticas públicas. Revista de Informação Legislativa, n. 138, abr-jun. 1998.

Para viver a democracia. São Paulo: Editora Brasiliense, 1989.

O indispensável direito econômico. Revista dos Tribunais, 353/14, mar. 1965.

CONCEIÇÃO, Luan Pedro Lima da. O federalismo fiscal e o critério do Valor Adicionado Fiscal. Revista Fórum de Direito Financeiro e Econômico, ano 05, n. 09, mar-ago. 2016.

CONGRESSO NACIONAL. Consultoria de Orçamentos, Fiscalização e Controle do Senado Federal. Consultoria de Orçamento e Fiscalização Financeira da Câmara dos Deputados. Nota Técnica Conjunta n. 7, 2015. Envio do PLOA 2016 ao Congresso Nacional com déficit primário - aspectos legais e regimentais. Brasília 2015.

CONSULTORIA DE ORÇAMENTO E FISCALIZAÇÃO FINANCEIRA - CONOF. Financiamento da saúde: Brasil e outros países com cobertura universal. Nota Técnica n. 012. Câmara dos Deputados, 2013.

CONTE, Nelton Carlos. FUNDEF e FUNDEB: efeitos redistributivos e impacto nas finanças dos municípios do Estado do Rio Grande do Sul. Tese (Doutorado). Universidade de Santa Cruz do Sul. Santa Cruz do Sul, 2017.

CONTI, José Maurício. O planejamento orçamentário da administração pública no Brasil. Tese (Concurso para provimento do cargo de Professor Titular). Universidade de São Paulo. São Paulo, 2017.

Tribunais de Contas são os guardiões do dinheiro público. In: CONTI, José Maurício. Levando o direito financeiro a sério. São Paulo: Blucher, 2016.

O orçamento público e o financiamento da educação no Brasil. In: HORVATH, Estevão; CONTI, José Maurício; SCAFF, Fernando Facury (Org.). Direito Financeiro, Econômico e Tributário: homenagem a Regis Fernandes de Oliveira. São Paulo: Quartier Latin, 2014.

. O Estado e o imposto: federalismo financeiro e fiscal. In: CATARINO, João Ricardo; GUIMARÃES, Vasco Branco (Coord.). Lições de fiscalidade. Coimbra: Almedina, 2012.

Arts. 22 a 33. In: CONTI, José Maurício (Coord.). Orçamentos públicos: a Lei 4.320/1964 comentada. 2. ed. rev. e atual. São Paulo: Editora Revista dos Tribunais, 2010. 
Planejamento e Responsabilidade Fiscal. In: SCAFF, Fernando Facury; e CONTI, José Maurício (Coord.). Lei de responsabilidade fiscal: 10 anos de vigência - questões atuais. Florianópolis: Conceito Editorial, 2010.

Considerações sobre o federalismo fiscal brasileiro em uma perspectiva comparada. In: CONTI, José Maurício; SCAFF, Fernando Facury; BRAGA, Carlos Eduardo Faraco (Org.). Federalismo fiscal: questões contemporâneas. Florianópolis: Conceito, 2010. . A autonomia financeira do Poder Judiciário. São Paulo: MP Editora, 2006. . Federalismo fiscal e fundos de participação. São Paulo: Juarez de Oliveira, 2001. 1998. Direito financeiro na Constituição de 1988. $1^{\text {a }}$. ed. São Paulo: Oliveira Mendes, . Princípios tributários da capacidade contributiva e da progressividade. São Paulo: Dialética, 1996.

CORREAS, Óscar. Introdução: El neoliberalismo en el imaginario juridico. In: MARQUES NETO, Agostinho Ramalho; COUTINHO, Jacinto Nelson de Miranda; RAMOS FILHO, Wilson; GOMES, Manoel Eduardo Alves Camargo e; FACHIN, Luiz Edson. Direito e neoliberalismo: elementos para uma leitura interdisciplinar. Curitiba: EDIBEJ, 1996.

CORREIA NETO, Celso de Barros. O avesso do tributo. 1. ed. São Paulo: Almedina, 2014. CORSEUIL, Carlos Henrique; MOURA, Rodrigo Leandro. O impacto do SIMPLES federal no nível de emprego da indústria brasileira. IPEA, Texto para discussão n. 1643, ago. 2011.

CORTI, Horacio G. Derecho constitucional presupuestario. Buenos Aires: Lexis Nexis Argentina, 2007.

COSTA, Alcides Jorge. Capacidade contributiva. Revista de Direito Tributário, n. 55, janmar. 1991.

COSTA, Alcides Jorge. Substituição Tributária. In: ROCHA, Valdir de Oliveira (Coord.). Grandes questões atuais de direito tributário. $18^{\circ}$ v. São Paulo: Dialética, 2014. $\overline{\operatorname{mar} 1990 .}$.

IPTU - progressividade. Revista de Direito Público. São Paulo, v. 23, n. 93, jan-

COSTA, Luiz Renato Lima da. Os critérios de alocação de recursos financeiros no Sistema Único de Saúde: uma visão a partir das Normas Operacionais, 1991 a 2002. Dissertação (Mestrado). Fundação Getúlio Vargas. São Paulo : EAESP/FGV, 2003.

COSTA, Regina Helena. Apontamentos sobre a tributação ambiental no Brasil. In: TÔRRES, Heleno Taveira (org.). Direito Tributário Ambiental. São Paulo: Malheiros, 2005. p. 330. Em sentido semelhante: OLIVEIRA, José Marcos Domingues. Meio ambiente tributação e vinculação de impostos. Revista de Direito Tributário, v. 15, n. 56, abr-jun. 1991.

COUTINHO, Diogo R. Direito, desigualdade e desenvolvimento. São Paulo: Saraiva, 2013. O direito nas políticas públicas. In: MARQUES, Eduardo; FARIA, Carlos Aurélio Pimenta de (orgs.). A política pública como campo multidisciplinar. São Paulo: UNESP, 2013. 
COUTINHO, João Pereira. A desigualdade não é imoral. Folha de São Paulo, 29 dez. 2015. Disponível http://www1.folha.uol.com.br/colunas/joaopereiracoutinho/2015/12/1723860-adesigualdade-nao-e-imoral.shtml. Acesso em 24 dez. 2017.

COWELL, Frank A.; VAN DE GAER, Dirk; HE, Chang. Inheritance taxation: redistribution and predistribution. 2017. STICERD - Public Economics Programme Discussion Papers 35, Suntory and Toyota International Centres for Economics and Related Disciplines - London School of Economics. Disponível em: <https://ideas.repec.org/p/cep/stippp/35.html> Acesso em 18 fev. 2018.

D’ABADIA, Bruno Magalhães. A problemática das transferências voluntárias. Consultoria Legislativa da Câmara dos Deputados: Brasília, mai. 2015.

DABLA-NORRIS, Era; KOCHHAR, Kalpana; SUPHAPHIPHAT, Nujin; RICKA, Frantisek; TSOUNTA, Evridiki. Causes and consequences of income inequality: a global perspective. International Monetary Fund, 2015.

DALLARI, Dalmo de Abreu. Implicações do pacto federativo. In: RAMOS, Dircêo Torrecillas (Coord.). O federalista atual: teoria do federalismo. Belo Horizonte: Arraes Editores, 2013.

DANTAS, Karlo Eric Galvão. A hipertrofia do Poder Executivo no processo orçamentário brasileiro. Brasília: ESAF, 2016. Monografia premiada com o terceiro lugar no IX Prêmio SOF de monografias - 2016.

DE CESARE, Claudia M. (Ed.). Sistemas del impuesto predial en América Latina y el Caribe. Cambridge, Massachusetts: Lincoln Institute of Land Policy, 2016.

DE CESARE, Claudia M.; DANTAS, Rubens Alves; RIBEIRTO, Jose Luis Duarte; PORTUGAL, José Luiz. La diversidad del reto: factores críticos del desempeño del impuesto a la propiedad inmobiliaria en Brasil. In: BONET, Jaime; MUÑOZ, Andrés; MANNHEIM, Carlos Pineda (Eds.). El potencial oculto: factores determinantes y oportunidades del impuesto a la propriedad inmobiliaria en América Latina. Banco Interamericano de Desarrollo. Washington, DC, 2014.

DE GIORGI, Raffaele; FARIA, José Eduardo; CAMPILONGO, Celso. Estado de coisas inconstitucional. Opinião. Estado de São Paulo, 19 set. 2015. Disponível em: http://opiniao.estadao.com.br/noticias/geral,estado-de-coisasinconstitucional,10000000043. Acesso em 31 jan. 2017.

DE MITA, Enrico. O princípio da capacidade contributiva. In: FERRAZ, Roberto (Coord.). Princípios e limites da tributação. São Paulo: Quartier Latin, 2005

DE NARDI, Mariacristina; YANG, Fang. Wealth Inequality, Family Background, and Estate Taxation. NBER Working Paper n. 21047, mar. 2015.

DE SANTI, Eurico Marcos Diniz; CHRISTOPOULOS, Basile Georges; ZUGMAN, Daniel Leib; BASTOS, Frederico Silva (Coord.). Transparência fiscal e desenvolvimento: homenagem ao professor Isaias Coelho. São Paulo: FISCOSoft, 2013.

DEATON, Angus. A grande saída: saúde, riqueza e as orignes da desigualdade. Trad. Marcelo Levy. Rio de Janeiro: Intrínseca, 2017. . How inequality works. Project Syndicate, 21 dez. 2017. 
DEODATO, Alberto. Manual de ciência das finanças. 20. ed. São Paulo: Saraiva, 1984.

DERENONCOURT, Ellora. The historical origins os global inequality. In: BOUSHEY, Heather; DELONG, J. Bradford; STEINBAUM, Marshall (eds.). After Piketty: the agenda for economics and inequality. Cambridge, Massachusstes, Londong, England: Harvard University Press, 2017.

DERZI, Misabel Abreu Machado; MAGALHÃES, Tarcísio Diniz. Levando a democracia a sério: uma abordagem da regra decisória ideal para o CONFAZ. Revista Jurídica da Presidência, v. 19, n. 117. Brasília, fev-mai. 2017.

.; BOTELHO, Cristiane Miranda; FIORINDO, Regivano. A distorção do sistema tributário nacional referente ao imposto de renda da pessoa física assalariada e do prestador de serviço. In: DERZI, Misabel Abreu Machado; MELO, João Paulo Fanucchi de Almeida (Coord.). Justiça Fiscal. Belo Horizonte: Del Rey, 2016.

Guerra fiscal, Bolsa Família e Silêncio (Relações, efeitos e regressividade). Revista jurídica da Presidência, v. 16, n. 108. Brasília, fev-mai 2014.

O princípio da não afetação da receita de impostos e a justiça distributiva. In: HORVATH, Estevão; CONTI, José Maurício; e SCAFF, Fernando Facury. Direito financeiro, econômico e tributário: homenagem a Régis Fernandes de Oliveira. São Paulo: Quartier Latin, 2014.

- Concorrência tributária e seus efeitos nos conceitos de renda e consumo. In: ROCHA, Valdir de Oliveira (Coord.). Grandes questões atuais do direito tributário. $17^{\circ}$ volume. São Paulo: Dialética, 2013.

DESMOND, Matthew. How homeownership became the engine of american inequality. New York Times, 09 mai. 2017. Disponível em: https://www.nytimes.com/2017/05/09/magazine/how-homeownership-became-the-engineof-american-inequality.html. Acesso em: 15 mai. 2017.

DIESSE. Nota Técnica - Imposto de renda pessoa física: propostas para uma tributação mais justa. Brasília, jan. 2017. Disponível em: <http://www.dieese.org.br/notatecnica/2017/notaTec169IRPF.pdf> Acesso em: 17 jan. 2018.

DOMINGUES, José Marcos. A atividade financeira do Estado e as políticas públicas para os Direitos Humanos. In: DOMINGUES, José Marcos (org.). Direito financeiro e políticas públicas. Rio de Janeiro: GZ, 2015.

A receita da despesa. Democracia financeira e bem-estar. In: HORVATH, Estevão; CONTI, José Maurício; SCAFF, Fernando Facury (Org.). Direito Financeiro, Econômico e Tributário: homenagem a Regis Fernandes de Oliveira. São Paulo: Quartier Latin, 2014.

. Revisitando o conceito de tributo. In: ABRAHAM, Marcus; FUX. Luiz. (Org.). Tributação e Justiça Fiscal. Rio de Janeiro: Editora GZ, 2014.

Tributação, orçamento e políticas públicas. Revista Tributária e de Finanças Públicas, col. 99, jul. 2011.

DORAN, Michael. Intergenerational equity in fiscal policy reform. Tax Law Review, n. 61, 2008. 
DORIA, Pedro. 5G, ICMS e Pnad. O Globo, 23 fev. 2018. Coluna Vida Digital. Disponível em: https://oglobo.globo.com/economia/5g-icms-pnad-22424398. Acesso em 23 fev. 2018.

DRAIBE, Sônia. A política social no período FHC e o sistema de proteção social. Tempo social, v. 15, n. 2, de nov. 2003.

DUARTE, Angelo José Mont'Alverne; SILVA, Alexandre Manoel Angelo da; LUZ, Everaldo Manoel; GERARDO, José Carlos. Transferências fiscais intergovernamentais no Brasil: uma avaliação das transferências federais, com ênfase no Sistema Único de Saúde. Texto para Discussão IPEA n. 1451, dez. 2009.

DUARTE, Ligia Schiavon. Desenvolvimento desigual e a regionalização do SUS: uma análise territorial dos recursos financeiros para as redes de atenção à saúde no Estado de São Paulo (2009-2014). Tese (Doutorado). Universidade de São Paulo. São Paulo, 2016.

DWORKIN, Ronald. A virtude soberana: a teoria e a prática da igualdade. Trad. Jussara Simões. $2^{\mathrm{a}}$ ed. São Paulo: Editora WMF Martins Fontes, 2011.

EASTERLY, William. Inequality does cause underdevelopment: insights from a new instrument. Journal of Development Economics, v. 84, n. 02, nov. 2007.

ECONOMIST, The. An hereditary meritocracy. 24 jan. 2015. Disponível em: $<$ https://www.economist.com/news/briefing/21640316-children-rich-and-powerful-areincreasingly-well-suited-earning-wealth-and-power> Acesso em 18 fev. 2018.

ELALI, André. Algumas considerações sobre neutralidade e não-discriminação em matéria de tributação. In: MARTINS, Ives Gandra da Silva; BRITO, Edvaldo (Orgs.). Direito tributário: princípios e normas gerais (Coleção doutrinas essenciais, v. 1). 2. ed. ampl. São Paulo: Editora Revista dos Tribunais, 2014.

ENGLISH, Jane. Justice between generations. Philosophical studies. An International Journal for Philosophy in the Analytic Tradition, v. 31, n. 2, fev. 1977

ESTADO DO RIO DE JANEIRO. Fundo de Participação dos Estados: A distribuição atual $\mathrm{faz}$ sentido? Disponível em: <http://www.fazenda.rj.gov.br/sefaz/content/conn/UCMServer/uuid/dDocName\%3AWCC 219026> Acesso em 04 mar. 2018.

ESTEVAN, Juan Manuel Barquero. La Función del tributo en el Estado Social y democrático de Derecho. Madrid: CEPC, 2002.

EUA - IPS - INSTITUTE FOR POLICY STUDIES. Corporate tax cuts boost CEO pay, not jobs. 24th annual executiva excesso. ago-2017. Disponível em: <http://www.ipsdc.org/report-corporate-tax-cuts-boost-ceo-pay-not-jobs/> Acesso em 24 fev. 2018.

EY. Estados elevam alíquota para herança e doações. 2017. Disponível em: $<$ http://www.ey.com/br/pt/newsroom/news-releases/release-estados-elevam-aliquota-paraherancas-e-doacoes> Acesso em 17 fev. 2018.

EY. Worldwide estate and inheritance tax guide 2014. Disponível em: <http://www.ey.com/Publication/vwLUAssets/Worldwide-Estate-and-Inheritance-TaxGuide-2014/\$FILE/Worldwide-Estate-and-Inheritance-Tax-Guide-2014.pdf> Acesso em 18 fev. 2018. 
FAJNZYLBER, Pablo; LEDERMAN, Daniel; LOAYZA, Norman. Inequality and Violent Crime. The Journal of Law and Economics, v. 45, n. 1, abr. 2002.

FALCK, Oliver; GOLLIER, Christian; WOESSMANN, Ludger. Arguments for and against policies to promote national champions. In: FALCK, Oliver; GOLLIER, Christian; WOESSMANN, Ludger (Eds.), Industrial policy for national champions. Cambridge: MIT Press, 2011

FALSITTA, Gaspare. Perfis da tutela constitucional da justiça tributária. In: MARTINS, Ives Gandra da Silva; BRITO, Edvaldo (Orgs.). Direito tributário: princípios e normas gerais (Coleção doutrinas essenciais, v. 1). 2. ed. ampl. São Paulo: Editora Revista dos Tribunais, 2014.

FAO - FOOD AND AGRICULTURE ORGANIZATION OF THE UNTED NATIONS. The state of food insecurity in the world 2014. Disponível em: http://www.fao.org/3/ai4030e.pdf> Acesso em 04 abr. 2018.

FARENZENA, Nalu. Políticas de assistência financeira da União no marco das responsabilidades (inter)governamentais em educação básica. In: GOUVEIA, André Barbosa; PINTO, José Marcelino de Rezende; CORBUCCI, Paulo Roberto (Orgs.). Federalismo e políticas educacionais na efetivação do direito à educação no Brasil. Brasília: IPEA, 2011.

FARIA, Anacleto de Oliveira. Do princípio da igualdade jurídica. São Paulo: Ed. Revista dos Tribunais, Ed. da Universidade de São Paulo, 1973.

FARIA, Rodrigo Oliveira de. PPA versus orçamento: uma leitura do escopo, extensão e integração dos instrumentos constitucionais brasileiros de planejamento. In: CONTI, José Maurício; SCAFF, Fernando Facury (Org.). Orçamentos públicos e direito financeiro. São Paulo: RT, 2011.

FARIAS, Luiz Roberto Barros. A tributação seletiva no IPI e no ICMS: indeterminação e controle do conceito de essencialidade. Dissertação (Mestrado). Universidade Federal de Alagoas. Maceió, 2017.

FARREL, Martin Diego. Filosofia del derecho y económia. Buenos Aires: La Ley, 2006.

FELDSTEIN, M. S. Income inequality and poverty. National Bureau of Economic Research Working Paper 6770, 1998.

FEREJOHN, John A.; KRAMER, Larry D. Independent judges, dependent judiciary : institutionalizing judicial restraint. New York University Law Review, v. 77, n. 962, out. 2002.

FERNANDES, Ivan Filipe de Almeida Lopes. A democracia reduz a desigualdade econômica? Tese (Doutorado). Universidade de São Paulo, 2014.

FERNANDES, Ricardo Vieira de Carvalho; GASSEN, Valcir. Tributação, desigualdade social e reforma tributária: os três Poderes e os objetivos da República. Revista Jurídica da Presidência, Edição comemorativa de 17 anos, 2016.

FERNÁNDEZ, F. Javier Martín. Los fines de los tributos. In: Comentarios a la Ley General Tributaria y lines para su reforma, libro-homenaje al profesor Sainz de Bujanda. Madrid: Instituto de Estudios Fiscales, 1991. 
FERRARI, Diogo Augusto. Descentralização Fiscal e Repartição da Receita Pública: o FPE na Constituinte de 1988. Dissertação (Mestrado). São Paulo: Universidade de São Paulo, 2013.

FERRAZ JUNIOR, Tércio Sampaio. Unanimidade ou maioria nas deliberações do CONFAZ - considerações sobre tema a partir do princípio federativo. Revista Fórum de Direito Tributário - RFDT, ano 10, n. 59, set-out. 2012. Disponível em: <http://www.bidforum.com.br/bid/PDI0006.aspx?pdiCntd=81870> Acesso em: 05 fev. 2018 .

Guerra Fiscal, Fomento e Incentivo na Constituição Federal. In: SCHOUERI, Luís Eduardo; ZILVETI, Fernando Aurélio. (coords.). Direito Tributário: Estudos em Homenagem a Brandão Machado. São Paulo: Dialética, 1998.

FERRAZ, Octávio Luiz Motta. A desigualdade não é imoral? Sobre as sutilezas do conceito de suficiência. Folha de São Paulo, 13 mar. 2016. Ilustríssima. Disponível em: http://m.folha.uol.com.br/ilustrissima/2016/03/1748903-a-desigualdade-nao-e-imoralsobre-as-sutilezas-do-conceito-de-suficiencia.shtml. Acesso em 24 dez. 2017.

FERRAZ, Roberto. Igualdade na tributação - qual o critério que legitima discriminações em matéria fiscal? In: FERRAZ, Roberto Catalano Botelho (Coord.). Princípios e limites da tributação. São Paulo: Quartier Latin, 2005.

Tributação ambientalmente orientada e as espécies tributárias no Brasil. In TÔRRES, Heleno Taveira (org.). Direito Tributário Ambiental. São Paulo: Malheiros, 2005.

FOLLONI, André. Isonomia na tributação extrafiscal. Revista Direito $G V$, v. 10, n. 01, janjun. 2014.

Direitos fundamentais, dignidade e sustentabilidade no constitucionalismo contemporâneo: e o Direito Tributário com isso? In: ÁVILA, Humberto (Org.). Fundamentos do Direito Tributário. Madri: Marcial Pons, 2012.

O papel da ciência do Direito Tributário no desenvolvimento nacional. Disponível em: <http://www.publicadireito.com.br/artigos/?cod=20dd77ae36c56353> Acesso em 16 mar. 2018.

; DIB, Natália. Notas sobre a tributação como bem jurídico coletivo. Revista de Estudos Constitucionais, Hermenêutica e Teoria do Direito (RECHTD), v. 7, n. 3, set-dez. 2015 .

FONSECA, Francisco. Estado, planejamento e gestão pública no Brasil contemporâneo. In: CARDOSO JR., José Celso; SANTOS, Eugênio A. Vilela dos. (Orgs.). PPA 2012-2015: experimentalismo institucional e resistência burocrática. Brasília: IPEA, 2015.

FONSECA, Ricardo Coelho da; BORGES, Djalma Freire. Tributação interestadual do ICMS e adoção do princípio do destino. Revista de Administração Pública, 39(1), jan-fev. 2005.

FRANCISCO, José Carlos. Comentários aos arts. 153 e 154. In: BONAVIDES, Paulo; MIRANDA, Jorge; AGRA, Walber de Moura (Coords.). Comentários à Constituição Federal de 1988. Rio de Janeiro: Forense, 2009. 
FRANCO NETO, Georgeno de Sousa. O uso dos depósitos judiciais e administrativos como fonte de receita: uma análise acerca da constitucionalidade da Lei Complementar n. 151/2015. Revista Fórum de Direito Financeiro e Econômico, ano 05, n. 09, mar-ago. 2016.

FRANKFURT, Harry. On inequality. Princeton and Oxford: Princeton University Press, 2015.

FREITAS, Antônio Albano de. O impacto da herança e de sua tributação na distribuição patrimonial e de rendimentos. Tese (Doutorado). Universidade Federal do Rio de Janeiro. Rio de Janeiro, 2017

FRUTUOSO, Jurandi. A gestão do Sistema Único de Saúde. In: OLIVEIRA, Romualdo Portela de; SANTANA, Wagner (Orgs.). Educação e federalismo no Brasil: combater as desigualdades, garantir a diversidade. Brasília: UNESCO, 2010.

FUJIWARA, Thomas; LAUDARES, Humberto; CAICEDO, Felipe Valencia. Tordesillas, Slavery and the Origins of Brazilian Inequality. Mimeo. 2017. Disponível em: <http://www.tinbergen.nl/wp-content/uploads/2017/09/Felipe-Caicedo-27-Sept.pdf>

Acesso em 01 abr. 2018.

FURTADO, Celso. Formação econômica do Brasil. 32. ed. São Paulo: Companhia Editora Nacional, 2005.

FURTADO, Celso. Uma política de desenvolvimento para o Nordeste. Novos Estudos Cebrap, São Paulo, v. 1, dez. 1981.

GAIGER SILVEIRA, Fernando. Equidade fiscal: impactos distributivos e do gasto social. Monografia apresentada perante o XVII Prêmio Tesouro Nacional. Brasília, 2012.

Equidade fiscal: impactos distributivos e do gasto social. Monografia apresentada perante o XVII Prêmio Tesouro Nacional. Brasília, 2012.

Tributação, previdência e assistência sociais: impactos distributivos. Tese (Doutorado). Universidade Estadual de Campinas. Campinas, 2008.

GALLO, Franco. Justiça social e justiça fiscal. In: FERRAZ, Roberto Catalano Botelho (Coord.). Princípios e limites da tributação 2. São Paulo: Quartier Latin, 2009.

Las razones del fisco: ética y justicia em los tributos. Tradução ao espanhol de José A. Rozas Valdés e Francisco Cañal. Nota preliminar de José A. Rozas Valdés. Madrid: Marcial Pons, 2007.

GARCIA, Felipe; SACHSIDA, Adolfo; CARVALHO, Alexandre Xavier Ywata de. Impacto da desoneração da folha de pagamentos sobre o emprego: novas evidências. IPEA, Texto para discussão n. 2357, 2018.

GARCIA, Ronaldo Coutinho. Despesas correntes da União: visões, omissões e opções. In: CARDOSO JR., José Celso; CUNHA, Alexandre dos Santos (Orgs.). Planejamento e avaliação de políticas públicas. Brasília: IPEA, 2015.

. Iniquidade social no Brasil: uma aproximação e uma tentativa de direcionamento. In: CARDOSO JR., José Celso; CUNHA, Alexandre dos Santos. (Orgs.). Planejamento e avaliação de políticas públicas. Brasília: IPEA, 2015. 
e CARDOSO JR., José Celso. Subsídios para repensar o sistema federal de planejamento. In: CARDOSO JR., José Celso; CUNHA, Alexandre dos Santos. (Orgs.). Planejamento e avaliação de políticas públicas. Brasília: IPEA, 2015.

GARGARELLA, Roberto. El nuevo constitucionalismo latino-americano. Estudios Sociales. Revista universitaria semestral, ano 2XXV, n. 48, de jan-jun 2015.

.; COURTIS, Christian. El nuevo constitucionalismo latino-americano: promesas e interrogantes. CEPAL - Série Políticas Sociales, n. 153, 2009. GARGARELLA, Roberto. La "sala de máquinas" de las constituciones latinoamericanas. Nueva Sociedad, n. 257, julago 2015.

. As teorias da justiça depois de Rawls: um breve manual de filosofia política. Trad. Alonso Reis Freire. rev. trad. Elza Maria Gasparotto; rev. téc. Eduardo Appio. São Paulo: WMF Martins Fontes, 2008.

GASPAR, Vitor; GARCIA-ESCRIBANO, Mercedes. Inequality: fiscal policy can make the difference. IMF blog, 11 out. 2017. Disponível em : https://blogs.imf.org/2017/10/11/inequality-fiscal-policy-can-make-the-difference/> Acesso em 07 abr. 2018.

GASPARINI, Carlos Eduardo; MIRANDA, Rogério Boueri. Evolução dos aspectos legais e dos montantes de transferências realizadas pelo Fundo de Participação dos Municípios. IPEA - Texto para Discussão n. 1243, dez. 2006.

GASSEN, Valcir; D’ARAÚJO, Pedro Júlio Sales; PAUlinO, Sandra Regina da F. Tributação sobre consumo: o esforço em onerar mais quem ganha menos. Revista Sequência, n. 66, jul. 2013.

(Org.). Equidade e eficiência da matriz tributária brasileira: diálogos sobre Estado, Constituição e direito tributário. Brasília: Editora Consulex, 2012.

GATES, Bill. Why inequality matters. 13 out. 2014. Disponível em: <https://www.gatesnotes.com/Books/Why-Inequality-Matters-Capital-in-21st-CenturyReview. Acesso em 06 abr. 2018.

GELCER, Daniel Monteiro. Redução das desigualdades regionais, federalismo cooperativo e planejamento econômico. Mimeo. 2015.

GEORGIADIS, Andreas; MANNING, Alan. Spend it like Beckham? Inequality and redistribution in the UK, 1983-2004. Centre for Economic Performance Discussion Paper n. 816, ago. 2017.

GERGGIANIN, Eugêncio. As deficiências do modelo autorizativo e as perspectivas do orçamento impositivo. Trabalho de Conclusão de Curso (Mestrado Profissional). Centro de Formação, Treinamento e Aperfeiçoamento da Câmara dos Deputados. Brasília, 2015.

GIACOMONI, James. Receitas vinculadas, despesas obrigatórias e rigidez orçamentária. In: CONTI, José Maurício; SCAFF, Fernando Facury (Org.). Orçamentos públicos e direito financeiro. São Paulo: RT, 2011.

GLAESER, Edward; SCHEINKMAN, Jose; SHLEIFER, Andrei. The injustice of inequality. NBER Working Paper n. 9150, set. 2002. 
GOBETTI, Sérgio Wulff. Apresentação Tributação da renda do capital: proposta de Reforma, datada de 02 out. 2017. Disponível em: <http://www.joserobertoafonso.com.br/tributacao-da-renda-do-capital-gobetti/> Acesso em 10 jan. 2018.

. Tributação da renda do capital e progressividade: o que fazer? In: AFONSO, José Roberto; LUKIC, Melina Rocha; ORAIR, Rodrigo Octávio; SILVEIRA, Fernando Gaiger (Orgs.). Tributação e desigualdade. Belo Horizonte: Letramento: Casa do Direito: FGV Direito Rio, 2017.

. Tributação do capital no Brasil e no mundo. 2017. No prelo.

.; ORAIR, Rodrigo Octávio. Progressividade tributária: a agenda negligenciada. Texto para discussão n. 2190. Brasília: IPEA, abr. 2016.

.; ORAIR, Rodrigo Octávio. Tributação e distribuição da renda no Brasil: novas evidências a partir das declarações tributárias das pessoas físicas. Centro Internacional de Políticas para o Crescimento Inclusivo (IPC-IG) Working Paper n. 136, fev. 2016.

GODOI, Marciano Seabra de. Tributação do consumo e efeitos redistributivos: alíquotas reduzidas conforme a essencialidade dos produtos/serviços (seletividade) versus alíquotas uniformes com transferências financeiras (refundable tax credits) para famílias de baixa renda. In: AFONSO, José Roberto; LUKIC, Melina Rocha; ORAIR, Rodrigo Octávio; SILVEIRA, Fernando Gaiger (Orgs.). Tributação e desigualdade. Belo Horizonte: Letramento: Casa do Direito: FGV Direito Rio, 2017.

Tributação e orçamento nos 25 anos da Constituição de 1988. Revista de Informação Legislativa, ano 50, n. 200, out-dez 2013.

GOMES, Sandra. Políticas nacionais e implementação subnacional: uma revisão da descentralização pós-Fundef. DADOS - Revista de Ciências Sociais, Rio Janeiro, v. 52, n. 3, 2009.

GÓMEZ, Juan Carlos; ROSSIGNOLO, Darío. La tributación sobre las altas rentas en América Latina. JIMÉNEZ, Juan Pablo (Ed.). Desigualdad, concentración del ingreso y tributación sobre las altas rentas en América Latina. Santiago: CEPAL, 2015.

GONÇALVES, Jane Reis. Direitos sociais, Estado de Direito e desigualdade: reflexões sobre as críticas à judicialização dos direitos prestacionais. Quaestio Juris, v. 08, n. 03, 2015.

GRAU, Eros Roberto. Planejamento econômico e regra jurídica. São Paulo: Editora Revista dos Tribunais, 1978.

GRECO, Marco Aurélio. Contribuições de Intervenção no domínio econômico - Parâmetros para sua criação. In GRECO, Marco Aurélio [coord.]. Contribuições de intervenção no domínio econômico e figuras afins. São Paulo: Dialética, 2001

IPTU: progressividade, função social da propriedade. Revista de Direito Tributário. São Paulo, v. 14, n. 52, abr-jun 1990.

GRUPENMACHER, Betina Treiger. IPTU, ITBI e capacidade contributiva: diversidade de bases de cálculo e critérios para a progressividade. 2014. Disponível em: http://www.ibet.com.br/iptu-itbi-e-capacidade-contributiva-diversidade-de-bases-decalculo-e-criterios-para-a-progressividade-por-betina-treiger-grupenmacher. Acesso em 01 
mai. 2018.GUIMARÃES, Bruno A. François. A seletividade do ICMS sobre o fornecimento de energia elétrica e sua repetição de indébito. Revista Direito Tributário Atual, n. 37, 2017. GUIMARÃES, Sônia Karam. Desenvolvimento econômico-social e instituições no Brasil. Revista Civitas, v. 16, n. 2, abr-jun 2016.

GUTIERREZ, Miguel Delgado. O imposto de renda e os princípios da generalidade, da universalidade e da progressividade. Tese (Doutorado). São Paulo: Universidade de São Paulo, 2009.

GUZMÁN, Tomás J. López-Guzmán. Fiscalidad ambiental: análisis y efectos distributivos. Granada: Ecorama, 2002.

HABER NETO, Michel. Transparência fiscal e sigilo tributário. Tese (Doutorado). Universidade de São Paulo. São Paulo, 2016;

HABER NETO, Michel. Tributação e financiamento da saúde pública. São Paulo: Quartier Latin, 2013.

HAGER, Sandy Brian. Public debt, inequality and power : the making of a modern debt State. Oakland: University of California Press, 2016.

HANNI, Michael; MARTNER, Ricardo; PODESTÁ, Andrea. El potencial redistributivo de la fiscalidad en América Latina. Revista CEPAL, n. 116, ago. 2015.

HARADA, Kiyoshi. Direito Financeiro e Tributário. 25. ed., rev., atual. e ampl. São Paulo: Atlas, 2016.

ICMS incidente sobre consumo de energia elétrica. Revista Fórum de Direito Tributário, v. 06, n. 36, nov. 2008.

Correção da tabela do IR. Revista Virtual da AGU, ano II n. 16, nov. 2001. Disponível em: <http://www.agu.gov.br/page/download/index/id/886207> Acesso em 17 jan. 2018.

HARGER, Marcelo. O SIMPLES e o princípio da isonomia. In: MARTINS, Ives Gandra da Silva; BRITO, Edvaldo (Orgs.). Direito tributário: princípios e normas gerais (Coleção doutrinas essenciais, v. 1). 2. ed. ampl. São Paulo: Editora Revista dos Tribunais, 2014.

HATGIOANNIDES, John; KARANASSOU, Marika; SALA, Hector. Should the rich be taxed more? The fiscal inequality coefficient. Disponível em: http://openaccess.city.ac.uk/18086/. Acesso em 20 jan. 2018.

HENRIQUES, Elcio Fiori. Os benefícios fiscais no direito financeiro e orçamentário: o gasto tributário no direito brasileiro. São Paulo: Quartier Latin, 2010.

HOLMES, Stephen; SUNSTEIN, Cass. The cost of rights: why liberty depends on taxes. Nova York: W. W. Norton \& Company, 1999.

HORVATH, Estevão. O orçamento no século XXI: tendências e perspectivas. Tese (Concurso para provimento de cargo de Professor Titular). Faculdade de Direito da Universidade de São Paulo. São Paulo, 2014.

. Mesa de debates no VI Congresso Brasileiro de Direito Tributário. Revista de Direito Tributário, n. 60. São Paulo: Malheiros, 1992. 
IBGE - INSTITUTO BRASILEIRO DE GEOGRAFIA E ESTATÍSTICA. PNAD Contínua 2016: $10 \%$ da população com maiores rendimentos concentra quase metade da renda. Release de 29 nov. 2017. Disponível em: <https://agenciadenoticias.ibge.gov.br/agenciasala-de-imprensa/2013-agencia-de-noticias/releases/18376-pnad-continua-2016-10-dapopulacao-com-maiores-rendimentos-concentra-quase-metade-da-renda.html> Acesso em 04 abr. 2018.

IFI - INSTITUIÇÃO FISCAL INDEPENDENTE. RAF. Relatório de Acompanhamento Fiscal n. 14, mar-2018.

INTERNATIONAL MONETARY FUND. Fiscal Monitor: Tackling inequality. Out. 2017. . Fiscal Monitor: Achieving more with less. Abr. 2017.

. Fiscal Monitor: Taxing times. Out. 2013.

INESC. Perfil da desigualdade e da injustiça tributária com base nos declarantes do Imposto de Renda no Brasil 2007-2013. Brasília, 2016.

INNERARITY, Daniel. A política em tempos de indignação. Trad. João Pedro George. Alfragide: D. Quixote, 2015.

INSTITUTO DE PESQUISA ECONÔMICA APLICADA. Acesso aos fundos regionais $e$ incentivos fiscais: avaliação qualitativa de ofertantes, demandantes e atores locais. Relatório de Pesquisa. IPEA: Brasília, 2015.

Uma avaliação da Política Nacional de Desenvolvimento Regional (PNDR): Diagnóstico da aplicação dos recursos do Fundo Constitucional de Financiamento do Nordeste (FNE), do Norte (Norte) e do Centro-Oeste (FCO). Relatório de Pesquisa. IPEA: Brasília, 2015.

. Equidade fiscal no Brasil: impactos distributivos da tributação e do gasto social. Comunicado do IPEA n. 92, 19 mai. 2011. Brasília: IPEA, 2011.

Comunicado n. 71. Desigualdade regional recente: uma nota a partir de dados estaduais. Brasília, 2010. Brasília, 2009.

Política fiscal e justiça social: o caso do IPTU. Comunicado da Presidência n. 28.

IVERSEN, Torben; SOSKICE, David. Electoral institutions and the politics of coalitions: why some democracies redistributemore than others. The American Political Science Review, v. 100, n. 02, mai. 2006.

IVO, Gabriel. Direito tributário e orçamento público. In: SCHOUERI, Luís Eduardo (Coord.). Direito tributário: homenagem a Paulo de Barros Carvalho. São Paulo: Quartier Latin, 2008.

JACOBS, Elisabeth. Everywhere and nowhere: politics in Capital in the Twenty-First Century. In: BOUSHEY, Heather; DELONG, J. Bradford; STEINBAUM, Marshall (eds.). After Piketty: the agenda for economics and inequality. Cambridge, Massachusstes, Londong, England: Harvard University Press, 2017.

JASSO, Guillermina. In(Equality) ans (In)Justice. Civitas - Revista de Ciências Sociais, v. 16, n. 02, abr-jun. 2016.

JENCKS, Christopher. Does inequality matter? Daedalus, v. 131, n. 01, inverno/2002. 
JENKINS, Stephen P.; VAN KERM, Philippe. The measurement of economic inequality. In: SALVERDA, Wiemer; NOLAN, Brian; SMEEDING, Timothy M. (Eds.). The Oxford handbook of economic inequality. Oxford University Press, 2009.

JIMÉNEZ, Juan Pablo (Ed.). Desigualdad, concentración del ingreso y tributación sobre las altas rentas en América Latina. Santiago: CEPAL, 2015.

JOBIM, Nelson (Presidente); MACIEL, Everardo (Relator); APPY, Bernard; LAMOUNIER, Bolívar; REZENDE, Fernando; MARTINS, Ives Gandra da Silva; VELLOSO, João Paulo dos Reis; BARROSO, Luís Roberto; BRANDÃO, Manoel Felipe do Rêgo; MARRAFON, Marco Aurélio; GARTENKRAUT, Michal; CARVALHO, Paulo de Barros; PRADO, Sérgio Roberto Rios do. Relatório Parcial: Comissão Especial Externa do Senado Federal criada pelo RQS $n$. 25, com a finalidade de analisar e propor soluções para questões relacionadas ao Sistema Federativo. Brasília, out. 2012.

JORDÃO, Eduardo. Um Supremo Tribunal Regimental? In: FALCÃO, Joaquim; ARGUELHES, Diego Werneck; RECONDO, Felipe (Orgs.). Onze supremos: o supremo em 2016. Belo Horizonte: Letramento: Casa do Direito: Supra: Jota: FGV Rio, 2017.

JORNAL DO COMÉRCIO. Entrevista especial: 'Tributação brasileira é escandalosamente benéfica aos muito ricos', diz economista. 04 dez. 2017. Disponível em: <http://jcrs.uol.com.br/_conteudo/2017/12/politica/599446-tributacao-brasileira-e-

escandalosamente-benefica-aos-muito-ricos--diz-economista.html> Acesso em 18 fev. 2018 .

KALLBEKKEN, Steffen; AASEN, Marianne. The demand for earmarking: results from a focus group study. Ecological Economics, v. 69, Issue 11, 2010.

KAPLOW, Louis. Taxation and redistribution: some clarifications. Harvard Law and Economics Discussion Paper n. 424, jun. 2003.

KERSTENETZKY, Célia Lessa. Foi um pássaro, foi um avião? Redistribuição no Brasil no século XXI. Novos Estudos CEBRAP, v. 36, n. 02, jul. 2017KERSTENETZKY, Celia Lessa. $O$ Estado de bem-estar social na idade da razão: a reinvenção do Estado social no mundo contemporâneo. Rio de Janeiro: Elsevier, 2012.

v. 45, n. 04, 2002.

Por que se importar com a desigualdade. DADOS - Revista de Ciências Sociais,

KIRKEGAARD, Jacob Funk. Tax overhaul risks making the US tax and transfer system (even) more regressive. PIIE - Peterson Institute for International Economics Policy Brief, n. 17-28, out. 2017.

KIRKEGAARD, Jacob Funk; KOLB, Melina. How governments tax reduces inequality more than how they spend. Disponível em : https://piie.com/research/piie-charts/howgovernments-tax-reduces-inequality-more-how-they-spend> Acesso em 07 abr. 2018.

KLEIN, Ezra. The government is not a household, and shouldn't be run like onde. The Washington Post, 15 abr. 2011.

KOLBERT, Elizabeth. The psicology of inequality. The New Yorker, 15 jan. 2018. Disponível em : https://www.newyorker.com/magazine/2018/01/15/the-psychology-ofinequality. Acesso em 26 abr. 2018. 
KRUGMAN, Paul. Why we're in a New Gilded Age. Resenha de Capital in the Twenty-Forst Century, de Thomas Piketty. New York Review of Books, 08 mai. 2014. Disponível em: <http://www.nybooks.com/articles/2014 mai.08/thomaspikettynewgildedage/> Acesso em 18 fev. 2018.

LAFAYE, Caroline Guibet. Ethics of Inheritance. Philosophy today, v. 52, n. 01, 2008.

LAKS, Larissa; DE MARCHI, Cristiane. Possibilidades e limites de conciliação entre o princípio da capacidade contributiva e a tributação extrafiscal. Revista Tributária e de Finanças Públicas, v. 127, mar-abr. 2016.

LAPATZA, José Juan Ferreiro. Instituciones de derecho financiero. Madrid Marcial Pons, 2010.

LAUDARES, Humberto. Ready to Tax: What Happens When Brazilian Municipalities Invest in Fiscal Capacity? 2016.2 Disponível em: <http://www.joserobertoafonso.com.br/attachment/20809> Acesso em 13 fev. 2018.

LAVINAS, Lena. A financeirização da política social: o caso brasileiro. Revista Politika, n. 02, mar. 2015. Disponível em: <https://issuu.com/fjmangabeira/docs/revista_politika__portugues> Acesso em 21 jan. 2017.

2014.

. A long way from tax justice: the brazilian case. GLU Working paper n. 22, abr.

LAZZARINI, Sergio; MUSACCHIO, Aldo; BANDEIRA-DE-MELLO, Rodrigo; MARCON, Rosilene. What do state-owned development banks do? Evidence from BNDES. World Development, v. 66, 2015.

LEITÃO-PAES, Nelson. Reflexos do SIMPLES Nacional no emprego e na formalização do mercado de trabalho no Brasil. Economía, Sociedad y Territorio, v. xv, núm. 49, 2015.

LEMOS, Amanda; CASTRO, Daniel E. de; PORTINARI, Natália. Morar em favela do Rio é agravante em condenação por tráfico de drogas. Folha de São Paulo, 27.abril.2018

LEONATTI, Carlos Araújo. O imposto sobre a renda das pessoas físicas como instrumento de justiça social no Brasil atual. Tese (Doutorado). Universidade Federal de Santa Catarina. Florianópolis, 2002.

LETTIERI, Marcelo. Imposto de renda das pessoas físicas no Brasil: a desigualdade escancarada. In: AFONSO, José Roberto; LUKIC, Melina Rocha; ORAIR, Rodrigo Octávio; SILVEIRA, Fernando Gaiger (Orgs.). Tributação e desigualdade. Belo Horizonte: Letramento: Casa do Direito: FGV Direito Rio, 2017.

LEVIN-WALDMAN, Oren M. How Inequality Undermines Democracy. E-International Relations, 10 dez. 2016. Disponível em: http://www.e-ir.info/2016/12/10/how-inequalityundermines-democracy/> Acesso em 06 abr. 2018.

LIMA, Adilson Nunes de. Renúncias fiscais da União. Consultoria Legislativa da Câmara dos Deputados, 2017.

LIMA, Bianca Pinto; SANTOS, Bárbara Ferreira. Repasse da União ao Fundeb triplica, mas desigualdade regional se mantém. O Estado de São Paulo, 14 set. 2014. Disponível em: http://educacao.estadao.com.br/noticias/geral,repasse-da-uniao-ao-fundeb-triplica-masdesigualdade-regional-se-mantem,1559690. Acesso em 03 mai. 2018. 
LIMA, Edilberto Carlos Pontes. Transferências da União para estados e municípios nãooriginárias de repartição de receitas: para que se destinam e o que determina o montante. Disponível em: http://federativo.bndes.gov.br/bf_bancos/estudos/e001768pdf Acesso em: 15 de jun. 2015.

LIMA, Luciana Dias de. Conexões entre o federalismo fiscal e o financiamento da política de saúde no Brasil. Ciênc. saúde coletiva. Rio de Janeiro, v. 12, n. 2, 2007. Disponível em: $<$ www.scielo.br/scielo.php?script=sci_arttext\&pid=S1413-

$81232007000200027 \& \operatorname{lng}=$ en\&nrm=iso > Acesso em 30 jun. 2015.

LINHARES, Paulo de Tarso Frazão; MENDES, Constantino Cronemberger; LASSANCE, Antonio (Orgs.). Federalismo à Bbrasileira: questões para discussão. Brasília: IPEA, 2012.

LIS, Laís. TCU autoriza governo a usar verba de fundo de telecomunicações para cumprir 'regra de ouro'. G1 Economia, 02.maio.2018. Disponível em: https://g1.globo.com/economia/noticia/tcu-autoriza-governo-a-usar-venda-de-fundo-detelecomunicacoes-para-cumprir-regra-de-ouro.ghtml. Acesso em 05.maio.2018.

LOCHAGIN, Gabriel Loretto. A execução do orçamento público: flexibilidade e orçamento impositivo. São Paulo: Blucher, 2016.

LODI RIBEIRO, Ricardo. Piketty e a reforma tributária igualitária no Brasil. Revista de Finanças Públicas, Tributação e Desenvolvimento, v. 03, n. 03. 2015.

. A correção da tabela do Imposto de Renda de acordo com a inflação. In: Anais da XXII Conferência Nacional dos Advogados: Constituição democrática e efetivação dos direitos. 2014.

LONGINOTTI, Fernando Peláez. Overview of tax expenditures in Latin America, main statistics of the CIAT database. Inter-American Center of Tax Administrations (CIAT) Working Paper. nov. 2017.

LOPES, José Reinaldo Lima. Régua e compasso - ou metodologia para um trabalho jurídico sensato. Mimeo. Texto publicado em espanhol como: Reglás y compás. In COURTS, Christian (org.). Observar la ley, Madrid, Editorial Trotta, 2006.

LUCHETE, Felipe. Limite para descontar despesa com educação do IR é julgado inconstitucional. Consultor Jurídico Matéria datada 17 jan. 2017. Disponível em: $<$ https://www.conjur.com.br/2017-jan-17/limite-deduzir-gasto-educacao-irinconstitucional> Acesso em 20 jan. 2018.

LUKIC, Melina de Souza Rocha. ICMS: entraves jurídicos e econômicos e propostas de melhoria. In: SACHSIDA, Adolfo (Org.). Tributação no Brasil: estudos, ideias e propostas: ICMS, seguridade social, carga tributária, impactos econômicos. Brasília: IPEA, 2017.

Tributação e equidade social: fundamentos constitucionais e precedentes do Supremo Tribunal Federal (STF). In: AFONSO, José Roberto; LUKIC, Melina Rocha; ORAIR, Rodrigo Octávio; SILVEIRA, Fernando Gaiger (Orgs.). Tributação $e$ desigualdade. Belo Horizonte: Letramento: Casa do Direito: FGV Direito Rio, 2017.

LUPION, Bruno. Qual o custo para os cofres públicos da dedução de saúde e educação no Imposto de Renda. Nexo Jornal, 26 abr-2017. Disponível em: <https://www.nexojornal.com.br/expresso/2017/04/26/Qual-o-custo-para-os-cofres- 
p\%C3\%BAblicos-da-dedu\%C3\%A7\%C3\%A3o-de-sa\%C3\%BAde-e-

educa \%C3\%A7\%C3\%A3o-no-Imposto-de-Renda> Acesso em 20 jan. 2018.

MACHADO, Cristiani Vieira. O papel federal no sistema de saúde brasileiro. In: Fundação Oswaldo Cruz. A saúde no Brasil em 2030 - prospecção estratégica do sistema de saúde brasileiro: organização e gestão do sistema de saúde. Rio de Janeiro: Fiocruz/Ipea/Ministério da Saúde/Secretaria de Assuntos Estratégicos da Presidência da República, 2013.

MACHADO, Hugo de Brito. Curso de direito tributário. 36. ed., rev. e atual. São Paulo: Malheiros Editores, 2015

. Proibição da guerra fiscal e a redução das desigualdades regionais. In: ROCHA, Valdir de Oliveira (Coord.). Grandes questões atuais de direito tributário. $15^{\circ}$ volume. São Paulo: Dialética, 2011.

Comentários ao art. 155. In: BONAVIDES, Paulo; MIRANDA, Jorge; AGRA, Walber de Moura (Coords.). Comentários à Constituição Federal de 1988. Rio de Janeiro: Forense, 2009.

MACIEL, Marcelo Sobreiro. Política de incentivos fiscais: quem recebe isenção por setores e regiões do país. Consultoria Legislativa da Câmara dos Deputados, 2010.

MAGALHÃES, José Luiz Quadros de. Comentários ao art. $3^{\circ}$. In: BONAVIDES, Paulo; MIRANDA, Jorge; AGRA, Walber de Moura (Coords.). Comentários à Constituição Federal de 1988. Rio de Janeiro: Forense, 2009. p. 33.

MAHON JR., James E.; BERGMAN, Marcelo; ARNSON, Cynthia J. Introduction. In: MAHON JR., James E.; BERGMAN, Marcelo; ARNSON, Cynthia J. (Eds.). Progressive tax reform and equality in Latin America. Washington, DC: Wilson Center, 2015.

MANKIW, N. Gregory. Yes, r > g. So what? American Economic Review: papers \& proceedings, v. $105, \mathrm{n}^{\circ} 05$, de maio/2015

MANOEL, Alexandre; RANCIARO NETO, Adhemar; MONTEIRO NETO, Aristides. Análise dos ratings dos Estados brasileiros: todos deveriam se endividar? Nota Técnica n. 10. Brasília: IPEA, mai. 2016.

MARKEVICH, Andrei; ZHURAVSKAYA, Ekaterina. The economic effects of the abolition of serfdom: evidence from the Russian Empire. American Economic Review, 108 (4-5), 2018.

MARKOVITS, Daniel. How much redistribution should there be? Yale Law Journal, v. 112, n. 8, 2003.

MARQUES, Rogério Cesar; ANGELO, Luiz Raphael Vieira. Interpretação constitucional do princípio da seletividade tributária no IPI e no ICMS. Fiscosoft, 2012. Disponível em: <http://www.fiscosoft.com.br/main_artigos_index.php?PID=269959\&printpage=_> Acesso em 23 mar. 2018.

MARTINEZ-VAZQUEZ, Jorge; McLURE, Charles; VAILLANCOURT, François. Revenues and expenditures in an intergovernmental framework. In: BIRD, Richard M.; VAILLANCOURT, François (Ed.). Perspectives on fiscal federalism. Washington: The World Bank, 2006. 
MARTINS JUNIOR, Wallace Paiva. Princípio da não afetação. In: CONTI, José Maurício; SCAFF, Fernando Facury (Org.). Orçamentos públicos e direito financeiro. São Paulo: RT, 2011.

MARTINS, André Malta. O ICMS e os produtos componentes da cesta básica nas unidades da federação. In: MARTINS, Ives Gandra da Silva; BRITO, Edvaldo (Orgs.). Direito tributário: impostos estaduais (Coleção doutrinas essenciais, v. 4). 2. ed. ampl. São Paulo: Editora Revista dos Tribunais, 2014.

MARTINS, Ives Gandra da Silva. A guerra fiscal na visão de Alcides Jorge Costa e na minha. In: PRETO, Raquel Elita Alves (Coord.). Tributação brasileira em evolução: estudos em homenagem ao Professor Alcides Jorge Costa. São Paulo: Editora IASP, 2015.

. O princípio da isonomia em matéria tributária: inteligência da MedProv 320/2006 rejeitada pelo Congresso Nacional. Atos e Portarias da Receita Federal vinculados à MedProv 320/2006. Eficácia após rejeição. In: MARTINS, Ives Gandra da Silva; BRITO, Edvaldo (Orgs.). Direito tributário: princípios e normas gerais (Coleção doutrinas essenciais, v. 1). 2. ed. ampl. São Paulo: Editora Revista dos Tribunais, 2014.

MARTINS, Paulo de Sena. O financiamento da educação básica por meio de fundos contábeis: estratégia política para a equidade, a autonomia e o regime de colaboração entre os entes federados. Tese (Doutorado). Universidade de Brasília. Brasília, 2009.

MARTORANO, Bruno. Taxation and inequality in developing countries: lessons from the recent experience on Latin America. WIDER Working Paper n. 2016/98, set. 2016.

MASSONETO, Luis Fernando. Os impactos da expansão financeira do capitalismo mundial - a constituição de um novo paradigma. In: HORVATH, Estevão; CONTI, José Maurício; SCAFF, Fernando Facury (Org.). Direito Financeiro, Econômico e Tributário: homenagem a Regis Fernandes de Oliveira. São Paulo: Quartier Latin, 2014.

$O$ direito financeiro no capitalismo contemporâneo: a emergência de um novo padrão normativo. Tese (Doutorado). Universidade de São Paulo, 2006.

MATIAS PEREIRA, José. Finanças públicas: a política orçamentária no Brasil. 2. ed. São Paulo: Atlas, 2003.

MATTOS, Aroldo Gomes de. ICMS - Comentários à Legislação Nacional. São Paulo: Dialética, 2006.

McCLEARY, William. The earmarking of government revenue: a review of some World Bank experience. The World Bank Research Observer, v. 6, n. 1, jan. 1991.

MEDEIROS, Marcelo; CASTRO, Fábio A. A composição da renda no topo da distribuição: evolução no Brasil entre 2006 e 2012, a partir de informações do imposto de renda, ago. 2016. Disponível em: <https://ssrn.com/abstract=2804612> Acesso em 04 abr. 2018.

; GALVÃO, Juliana de Castro. Educação e rendimentos dos ricos no Brasil. DADOS - Revista de Ciências Sociais, v. 59, n. 2, 2016.

.; SOUZA, Pedro. Gasto público, tributos e desigualdade de renda no Brasil. Texto para discussão n. 1844. Brasília: IPEA, 2013.

; FERREIRA DE SOUZA, Pedro Herculano Guimarães; CASTRO, Fábio Ávila de. A estabilidade da desigualdade de renda no Brasil, 2006 a 2012: estimativa com dados 
do imposto de renda e pesquisas domiciliares. Ciência \& Saúde Coletiva, v. 20, núm. 4, abr., 2015.

.. O que faz os ricos ricos: o outro lado da desigualdade brasileira. São Paulo: Hucitec: Anpocs, 2005.

.. Estrutura familiar e rendimentos do trabalho dos ricos. DADOS - Revista de Ciências Sociais, v. 47, n. 02, 2004.

MELO, João Paulo Fanucchi de Almeida. O nascimento da tributação e os diferentes fundamentos para o seu exercício na história e a igualdade como atual balizadora na justa tributação tendo a capacidade contributiva como sua medida de comparação. In: DERZI, Misabel Abreu Machado; MELO, João Paulo Fanucchi de Almeida (Coords.). Justiça Fiscal. Belo Horizonte: Del Rey, 2016.

MÉLO, Luciana Grassano de Gouvêa; CAMPOS, Giovanni Christian Nunes. A tributação sobre o patrimônio e a renda: mais um caso de injustiça fiscal. Revista do Programa de PósGraduação em Direito da UFBA, v. 26, n. 28, 2016.

MENDES, Conrado Hubner. Is it all about the last word? Deliberative separation of powers 1. Legisprudence, v. 03, n. 01, de 2009. Disponível em https://ssrn.com/abstract=1911822> Acesso em 21 mar. 2018

Not last word, but dialogue: deliberative separation of powers 2. Legisprudence, v. 03, n. 02, 2009. Disponível em https://ssrn.com/abstract=1911835> Acesso em 21 mar. 2018).

Direitos fundamentais, separação de poderes e deliberação. Tese (Doutorado). Universidade de São Paulo. São Paulo, 2008.

. Judicial Review of Constitutional Amendments in the Brazilian Supreme Court. Florida Journal of International Law, v. 17, n. 03, dez-2005.

MENDES, Constantino Cronemberger. Evolução fiscal e financeira dos estados brasileiros (2012-2015): desafios conjunturais e restrições estruturais. Boletim Regional, Urbano e Ambiental do IPEA, jul-dez. 2017.

MENDES, Gilmar Ferreira; CORREIA NETO, Celso de Barros. Transparência fiscal. In: MARTINS, Ives Gandra da Silva; MENDES, Gilmar Ferreira; NASCIMENTO, Carlos Valder do (Coord.). Tratado de Direito Financeiro. v. 1. São Paulo: Saraiva, 2013.

Tributação e finanças públicas na Constituição Federal de 1988. In: MENDES, Gilmar Ferreira; BRANCO, Paulo Gustavo Gonet. Curso de direito constitucional. 6. ed. rev. e atual. São Paulo: Saraiva, 2011.

MENDES, Marcos; APPY, Bernard. Injusto, ineficiente e caro. O Estado de São Paulo, 22 jan. 2016. Opinião. Disponível em: http://opiniao.estadao.com.br/noticias/geral,injusto-ineficiente-e-caro,10000013053. Acesso em 24 fev. 2018.

. Desigualdade e crescimento: uma revisão da literatura. Núcleo de Estudos e Pesquisas do Senado Federal - Texto para Discussão n. 131, ago. 2013.

.; MIRANDA, Rogério Boueri; COSIO, Fernando Blanco. Transferências intergovernamentais no Brasil: diagnóstico e proposta de reforma. Texto para discussão n. 40. Brasília: Consultoria legislativa do Senado Federal, abr. 2008. 
Despesas dos Poderes Autônomos: Legislativo, Judiciário e Ministério Público. In: MENDES, Marcos (org.). Gasto Público Eficiente: propostas para o desenvolvimento do Brasil. Rio de Janeiro: Topbooks Editora e Distribuidora de Livros Ltda., 2006.

MENDES, Marcos José. Fundo de Participação dos Estados: sugestão de novos critérios de partilha que atendam determinação do STF. In: LINHARES, Paulo de Tarso Frazão; MENDES, Constantino Cronemberger; LASSANCE, Antonio (Orgs.). Federalismo à Bbrasileira: questões para discussão. Brasília: IPEA, 2012.MENEZES FILHO, Naércio; KIRSCHBAUM, Charles. Educação e desigualdade no Brasil. In: ARRETCHE, Marta (Org.). Trajetória das desigualdades: como o Brasil mudou nos últimos cinquenta anos. 1. ed. São Paulo: Editora UNESP; CEM, 2015.

; ROCHA, Fabiana Fontes. Transferências intergovernamentais e captura de recursos públicos nos municípios brasileiros. Brasília: ESAF, 2003. Monografia agraciada com menção honrosa no VIII Prêmio Tesouro Nacional - 2003.

MENGARDO, Bárbara. Governo Temer será o primeiro a desobedecer a Regra de Ouro. E agora? JOTA, 30 abr. 2018. Disponível em: https://www.jota.info/legislativo/governotemer-desobedecer-regra-de-ouro-30042018 Acesso em 05.maio.2018.

MESQUITA, Patrick Bezerra. Caracterização do uso de depósitos judiciais pelo tesouro como operação de crédito: a crônica de um calote anunciado. Revista Fórum de Direito Financeiro e Econômico, ano 06, n. 11, mar-ago 2017.

METTLER, Suzanne. The Submerged State. Chicago: University of Chicago Press, 2011.

MILÁ, Marc Morgan. Income concentration in a context of late development: an investigation of top incomes in Brazil using tax records, 1933-2013. Dissertação (Mestrado) - Paris School of Economics, Paris, 2015.

MILANOVIC, Branko. The higher the inequality, the more likely we are to move away from democracy. The Guardian, 02 mai. 2017. Disponível em: https://www.theguardian.com/inequality/2017/may/02/higher-inequality-move-away-fromdemocracy-branko-milanovic-big-data Acesso em 28 abr. 2018.

Global innequality: a new approach for the age of globalization. Cambridge, The Belknap Press of Harvard University, 2016.

MINISTÉRIO DA FAZENDA. Demonstrativo dos Gastos Tributários: PLOA 2018. 2017.

MINISTÉRIO DA FAZENDA. RECEITA FEDERAL. CETAD - Centro de Estudos Tributários e Aduaneiros. Carga tributária no Brasil 2016: análise por tributos e bases de incidência. Brasília, dezembro/2017.

MINISTÉRIO DA FAZENDA. RECEITA FEDERAL. CETAD - Centro de Estudos Tributários e Aduaneiros. Carga tributária no Brasil 2015: análise por tributos e bases de incidência. Brasília, set. 2016.

MIRANDA, Ricardo Nunes de. Zona Franca de Manaus: desafios e vulnerabilidades. Núcleo de Estudos e Pesquisas do Senado Federal, Texto para discussão n. 126, abr. 2013.

MIRANDA, Tiago. Imposto sobre fortunas pode entrar no debate sobre reforma tributária. Agência Câmara Notícias. Publicado em 30 jul. 2015. Disponível em: $<$ http://www2.camara.leg.br/camaranoticias/noticias/ECONOMIA/492945-imposto-sobrefortunas-pode-entrar-no-debate-sobre-reforma-tributaria.html> Acesso em 12 fev. 2018. 
MIRRLEES, James. Tax By Design: The Mirrlees Review. Oxford University Press, 2011.

MIRRLEES, James. Tax By Design: The Mirrlees Review. Oxford University Press, 2011.

MONASTÉRIO, Leonardo. O FPM e a estranha distribuição da população dos pequenos municípios brasileiros. Texto para Discussão do IPEA n. 1818, mar. 2013.

MONTEIRO NETO, Aristides. Federalismo sem pactuação: governos estaduais na antessala da federação. In: MONTEIRO NETO, Aristides (Org.). Governos estaduais no federalismo brasileiro: capacidades e limitações governativas em debate. Brasília: IPEA, 2014.

Governos estaduais no federalismo brasileiro: capacidades e limitações no cenário atual. IPEA: texto para discussão n. 1894. Rio de Janeiro, nov. 2013.

MONTEIRO, Alexandre Luiz Moraes do Rêgo. A progressividade em suas facetas fiscal e extrafiscal. Uma releitura do instituto e de sua inter-relação com o Imposto Predial e Territorial Urbano (IPTU). Revista Tributária e de Finanças Públicas, v. 103, mar-abr. 2012.

MORAES, Líria Kédina Cuimar de Sousa e; OLIVEIRA, Phelippe Toledo Pires de. A controvérsia acerca da incidência do Imposto sobre a Propriedade de Veículos Automotores (IPVA) sobre embarcações e aeronaves. Caderno de Finanças Públicas, n. 14, dez. 2014.

MOREIRA, André Mendes; SENA, Roberto Miglio. (In)Justiça na tributação do consumo: o que a OCDE tem a os dizer. Revista de Finanças Públicas, Tributação e Desenvolvimento, v.4, n.4, 2016.

MOREIRA, Bernardo Motta. A seletividade e a progressividade das alíquotas do IPVA como realização da justiça fiscal. In: DERZI, Misabel Abreu Machado; MELO, João Paulo Fanucchi de Almeida (Coords.). Justiça Fiscal. Belo Horizonte: Del Rey, 2016.

MORGAN, Marc. Extreme and Persistent Inequality: New Evidence for Brazil Combining National Accounts, Surveys and Fiscal Data, 2001-2015. WID.world Working Paper Series $\mathrm{N}^{\circ}$ 2017/12. ago-2017. Disponível em: http://wid.world/wpcontent/uploads/2017/09/Morgan2017BrazilDINA-.pdf Acesso em 23 set. 2017.

Income inequality, growth and elite taxation in Brazil: new evidence combining survey and fiscal data, 2001-2015. International Policy Center for Inclusive Growth (IPCIG) Working paper n. 165, fev. 2018.

MORSCH, Natália de Azevedo. Justiça fiscal e neutralidade fiscal: a questão do ICMS nas operações interestaduais. Dissertação (Mestrado). Pontifícia Universidade Católica do Rio Grande do Sul. Porto Alegre, 2006.

MURPHY, Liam; e NAGEL, Thomas. O mito da propriedade: os impostos e a justiça. Tradução de Marcelo Brandão Cipolla. São Paulo: Martins Fontes, 2005.

. Quem é o povo? A questão fundamental da democracia. Tradução de Peter Naumann. São Paulo: Max Limonad, 1998.

NABAIS, José Casalta. O dever fundamental de pagar impostos. Coimbra: Livraria Almedina, 1998.

NAGEL, Thomas. Justice and Nature. Oxford Journal of Legal Studies, v. 17, n. 02, verão/1997. 
NASCIMENTO, Carlos Valder do. Planejamento e orçamento-programa. In: MARTINS, Ives Gandra da Silva; MENDES, Gilmar Ferreira; NASCIMENTO, Carlos Valder do (Coord.). Tratado de direito financeiro. v. 1. São Paulo: Saraiva, 2013.

NEVES, António. Imposto sucessório - passado, presente e futuro. Apresentação. Faculdade de Direito da Universidade Católica Portuguesa - Escola de Lisboa. Disponível em:

http://www.fd.lisboa.ucp.pt/resources/documents/CONFERENCIAS/2016/ImpostoSucesso rio_AntonioNeves.pdf Acesso em 17 fev. 2018.

NIELSEN, Eric. R. Human Capital and Wealth before and after Capital in the Twenty-First Century. In: BOUSHEY, Heather; DELONG, J. Bradford; STEINBAUM, Marshall (eds.). After Piketty: the agenda for economics and inequality. Cambridge, Massachusstes, Londong, England: Harvard University Press, 2017.

NÓBREGA, Marcos. Orçamento, eficiência e performance budget. In: CONTI, José Maurício; SCAFF, Fernando Facury (Org.). Orçamentos públicos e direito financeiro. São Paulo: RT, 2011.

NOGUEIRA, Roberto Passos. Critérios de jistuça distributiva em saúde. Texto para Discussão IPEA n. 1591, mar. 2011.

NOGUEIRA, Ruy Barbosa. 1. Poder tributário. 2. Conceito de Direito Tributário. 3. Autonomia. 4. Relações com outros ramos do Direito. In: MARTINS, Ives Gandra da Silva; BRITO, Edvaldo [Orgs.]. Direito tributário: princípios e normas gerais [Coleção doutrinas essenciais, v. 1]. 2. ed. ampl. São Paulo: Editora Revista dos Tribunais, 2014.

NORREGAARD, John. Tax Assignment. In: TER-MINASSIAN, Teresa (Ed.). Fiscal federalism in theory and practice. Washington: International Monetary Fund, 1997.

NORREGAARD, John. Taxing immovable property: revenue potential and implementation challenges. IMF Working Paper WP/13/129. 2013.

NUNES, Alynne Nayara Ferreira. Financiamento da educação básica no Brasil: uma análise dos arranjos jurídicos adotados ao longo do período republicano. Revista Digital de Direito Administrativo, v. 4, n. 1. 2017.

NUSDEO, Ana Maria. Desenvolvimento sustentável do Brasil e o protocolo de Quioto. Revista de Direito Ambiental, v. 37, 2005.

OATES, Wallace. On The Evolution of Fiscal Federalism: Theory and Institutions. National Tax Journal, v. LXI, n. 2. jun. 2008.

OCKÉ-REIS, Carlos Octávio; GAMA, Filipe Nogueira da. Radiografia do gasto tributário em saúde - 2003-2013. Nota Técnica n. 19. Brasília: IPEA, 2016.

. Mensuração dos gastos tributários: o caso dos planos de saúde-2003-2011. Nota Técnica n. 5. Brasília: IPEA, 2013.

OCTAVIANI, Alessandro. A bênção de Hamilton na semiperiferia: ordem econômicosocial e os juros da dívida pública. In: CONTI, José Maurício; SCAFF, Fernando Facury (Org.). Orçamentos públicos e direito financeiro. São Paulo: RT, 2011.

OECD/ECLAC/CIAT/IDB. Revenue statistics in Latin America and the Caribbean 2017. OECD Publishing. Paris, 2017. 
OCDE - ORGANISATION FOR ECONOMIC CO-OPERATION AND DEVELOPMENT. Income inequality (indicator). Doi: 10.1787/459aa7f1-en. Acesso em 20 jun. 2016.

Small businesses, job creation and growth: facts, obstacles and best practices. 1998. Disponível em: 〈https://www.oecd.org/cfe/smes/2090740.pdf> Acesso em 24 fev. 2018.

OLIVEIRA, Fabrício Augusto de; BIASOTO JR., Geraldo. A reforma tributária: removendo entraves para o crescimento, a inclusão social e o fortalecimento da federação. Texto para discussão n. 260. Instituto de Economia - UNICAMP. Campinas, 2015.

OLIVEIRA, Júlio Marcelo de. Securitização da dívida ativa enfraquece a responsabilidade fiscal. Consultor Jurídico, 27 out. 2016. Disponível em: <https://www.conjur.com.br/2016out-27/contas-vista-securitizacao-divida-ativa-enfraquece-responsabilidade-fiscal > Acesso em 11 mar. 2018.

OLIVEIRA, Regis Fernandes de. Indagação sobre os limites da ação do Estado. São Paulo: Editora Revista dos Tribunais, 2015.

. Federalismo fiscal e pacto federativo. Revista Tributária e de Finanças Públicas, v. 61, 2005; OLIVEIRA, Regis Fernandes de. Indagação sobre os limites da ação do Estado. São Paulo: Editora Revista dos Tribunais, 2015.

. Gastos públicos. São Paulo: Revista dos Tribunais, 2012.

. Curso de direito financeiro. 3. ed. rev. e atual. São Paulo: RT, 2010.

OLIVEIRA, Ribamar. Renda dos super-ricos aumentou na crise. Valor Economico, 21 fev. 2018. Disponível em: <http://www.valor.com.br/brasil/5337001/renda-dos-super-ricosaumentou-na-crise> Acesso em 22 fev. 2018.

OLIVEIRA, Ricardo Mariz de. Princípios fundamentais do imposto de renda. In: SCHOUERI, Luís Eduardo; ZILVETI, Fernando Aurélio. Direito tributário: estudos em homenagem a Brandão Machado. São Paulo: Dialética, 1998.

OLIVEIRA, Ricardo Mariz de; BIANCO, João Francisco; KARAM, Silvana Mancini; LUNARDELLI, Pedro Guilherme Accorsi. Princípios constitucionais tributários. In: MARTINS, Ives Gandra da Silva (Org.). Direito tributário: artigos selecionados em homenagem aos 40 anos do Centro de Extensão Universitária. São Paulo: Editora Revista dos Tribunais: Instituto Internacional de Ciências Sociais, 2012. v. 1.

OLIVEIRA, Romualdo Portela de; SOUZA, Sandra Zákia. Introdução. In: OLIVEIRA, Romualdo Portela de; SANTANA, Wagner (Orgs.). Educação e federalismo no Brasil: combater as desigualdades, garantir a diversidade. Brasília: UNESCO, 2010.

OLIVEIRA, Yonne Dolácio de. Progressividade do IPTU e princípios da capacidade contributiva e da redistribuição. Cadernos de Direito Tributário e Finanças Públicas, São Paulo, v. 5, n. 17, out-dez. 1996.

ORAIR, Rodrigo Octávio. Desonerações em alta com rigidez da carga tributária: o que explica o paradoxo do decênio 2005-2014? Texto para discussão n. 2117. Brasília: IPEA, ago. 2015.

OSTRY, Jonathan D.; BERG, Andrew. A redistribuição como tratamento para a desigualdade: a cura é pior do que a doença? IMFdirect blog, 26 fev. 2014. Disponível em: 
<https://www.imf.org/external/lang/portuguese/np/blog/2014/022614p.pdf> Acesso em 06 abr. 2018.

;___ _ _ TSANGARIDES, Charalambos G. Redistribution, inequality, and growth. IMF Staff Discussion Note SDN/14/02. fev. 2014.

OSTRY, Jonathan D.; LOUNGANI, Prakash; FURCERI, Davide. Neoliberalism: oversold? Finance and Development, jun. 2016.

OXFAM. Compensem o trabalho, não a riqueza. Resumo, jan. 2018. Disponível em: <https://www.oxfam.org.br/assim-nao-davos> Acesso em 18 fev. 2018.

A distância que nos une: um retrato das desigualdades brasileiras. 2017.

OXFAM Brasil; CESR. Direitos humanos em tempos de austeridade. Disponível em: $<$ http://www.inesc.org.br/noticias/noticias-do-inesc/biblioteca/publicacoes/outras-

publicacoes/direitos-humanos-em-tempos-de-austeridade/view> Acesso em 10 mar. 2018.

PAES, Nelson Leitão. A implantação do princípio do destino na cobrança do ICMS e suas implicações dinâmicas sobre os Estados. Revista Brasileira de Economia, v. 63, n. 3, jul-set. 2009.

PAES, Nelson Leitão. Gastos tributários: uma análise comparada. Revista de Estudos Sociais, ano 2012, n. 28, v. 14, 2012.

.; SIQUEIRA, Marcelo Lettieri. Desenvolvimento regional e federalismo fiscal no Brasil: em busca da igualdade na distribuição de receitas. Econ. Apl., v. 12, n. 4, 2008.

PAGE, Benjamin I.; BARTELS, Larry M.; SEAWRIGHT, Jason. Interviewing wealthy americans. Northwestern University Working Paper Series WP-11-07, 2011.

PAIVA, Andrea Barreto de; GONZALEZ, Roberto Henrique Sieczkowski; LEANDRO, José Geraldo. Coordenação federativa e financiamento da política de saúde. Novos Estudos CEBRAP, Edição 108, v. 36, n. 2, jul. 2017.

PAMPLONA, Karla Marques. O Estado federativo fiscal e o comportamento do sistema de transferências intergovernamentais na receita pública dos Municípios do Estado do Pará: uma análise sob as perspectivas da equalização fiscal $e$ do desenvolvimento. Tese (Doutorado). Universidade Federal do Pará. Belém, 2014.

PAULSEN, Leandro. Direito Tributário: Constituição e Código Tributário à Luz da Doutrina e da Jurisprudência, $11^{a}$ Edição. Porto Alegre: Livraria dos Advogados; ESMAFE, 2007.

PEREIRA, Paulo Trigo. A teoria da escolha pública (public choice): uma abordagem neoliberal? Análise Social, v. XXXII (141), 1997 (2º..

PIERSON, Paul. Coping with Permanent Austerity: welfare state restructuring in affluent democracies. In: PIERSON, Paul (Ed.). The New Politics of the Welfare State. Oxford: Oxford University Press, 2001.

The Price of Federalism. New York: Brookings Institution Press. 1995.

PIKETTY, Thomas. O capital no século XXI. Tradução de Monica Baumgarten de Bolle. 1. ed. Rio de Janeiro: Intrínseca, 2014. 
2014.

.; e SAEZ, Emmanuel. Inequality in the long run. Science, v. 344, n. 6186, mai.

. Theories of persistent inequality and intergenerational mobility. In: ATKINSON, Anthony B. ; BOURGUIGNON, François (eds.). Handbook of income distribution, v. 1. Amsterdam : Elsevier, 2000.

PIKETTY, Thomas; SAEZ, Emmanuel; ZUCMAN, Gabriel. Rethinking capital and wealth taxation. 2013. Mimeo. Disponível em http://piketty.pse.ens.fr/files/PikettySaez2014RKT.pdf> Acesso em 18 fev. 2018.

PIMENTA, Paulo Roberto Lyrio. As normas constitucionais programáticas e a reserva do possível. Revista de Informação Legislativa, na. 49, n. 193, jan-mar. 2012.

PINHEIRO, Heloisa Helena; WALTEMBER, Fabio; KERSTENETZKY, Célia Lessa. Imposto sobre a renda das pessoas físicas: oportunidades para tributar os rendimentos mais altos no Brasil. Centro de Estudos sobre Desigualdade e Desenvolvimento , Texto para discussão n. 121, mai. 2017.

PINTO, Élida Graziane. Financiamento de direitos fundamentais e federalismo: um estudo comparativo sobre a progressividade constitucionalmente conquistada na educação e a guerra fiscal de despesa na saúde do pós-EC 29/2000. Tese (Programa de Pós-Doutorado). Escola Brasileira de Administração Pública e de Empresas da Fundação Getúlio Vargas. 2010.

PINTO, Élida Graziane. Financiamento dos direitos fundamentais no Brasil pós-Plano Real. Tese (Doutorado). Mimeo. Belo Horizonte, 2006.

PINTO, Victor Carvalho. Qual é o valor jurídico das metas fiscais? O caso da LDO 2014. Disponível em: <http://www.brasil-economia-governo.org.br/2015/02/02/qual-e-o-valorjuridico-das-metas-fiscais-o-caso-da-ldo-2014/> Acesso em 14 mar. 2018.

PIOLA, Sérgio Francisco. Transferências de recursos federais do Sistema Único de Saúde para estados, Distrito Federal e municípios: os desafios para a implementação dos critérios da Lei Complementar n. 141/2012. Texto para discussão IPEA n. 2298, abr. 2017.

; PAIVA, Andrea Barreto de; SÁ, Edvaldo Batista de; SERVO, Luciana Mendes Santos. Financiamento público da saúde: uma história à procura de rumo. Texto para Discussão IPEA n. 1846, jul. 2013.

PISCITELLI, Tathiane. A progressividade de alíquotas como realização da justiça fiscal: distributivismo e capacidade contributiva. Disponível em: <http://www.ibet.com.br/aprogressividade-de-aliquotas-como-realizacao-da-justica-fiscal-distributivismo-e-

capacidade-contributiva-por-tathiane-piscitelli/ Acesso em 02 fev. 2018;

POLIZELLI, Victor Borges. Progressividade: distribuição de renda e indução. Revista Direito Tributário Atual, n. 21, 2007.

PORTER, Eduardo; RUSSEL, Karl. It's an unequal world. It doesn't have to be. New York Times, 14 dez. 2017.

PRADO, Sergio. A questão fiscal na federação brasileira: diagnóstico e alternativas. CEPAL, LC/BRS/R.179, mar. 2007.2 Disponível em: <http://repositorio.cepal.org/handle/11362/37929> Acesso em 31 jan. 2018. 
PRADO, Sérgio. FPE - equalização estadual no Brasil: alternativas e simulações para a reforma. v. 1. FGV Projetos; IDP, 2012.

PRASAD, Naren. Policies for redistribution: the use of taxes and social transfers. International Institute for Labour Studies Discussion Paper n. DP/194/2008.

PROCHNIK, Marta. Fontes de recursos do BNDES. Revista do BNDES, v. 2, n. 4, dez. 1995.

PROFETA, Paola; SCABROSETTI, Simona; WINER, Stanley L. Wealth transfer taxation: an empirical investigation. International Tax and Public Finance, v. 21, n. 04. ago. 2014.

PWC. New value creators gain momentum: billionaires insights. 2017. Disponível em: $<$ https://www.pwc.com/gx/en/industries/financial-services/publications/billionairesinsights.html> Acesso em 18 fev. 2018.

QUEIROZ E SILVA, Jules Michelet Pereira; ARAÚJO, José Evande Carvalho. Medidas antielisivas na instituição e cobrança do Imposto sobre Grandes Fortunas (IGF). Consultoria Legislativa da Câmara dos Deputados. Brasília, 2015.

RATHKE, Alex Augusto Timm; SILVA, Cíntia do Nascimento; SILVA, Fabio Pereira da. Disparidade de carga tributária na transição do Microempreendedor Individual (MEI) para a Microempresa (ME). Revista da Receita Federal: estudos tributários e aduaneiros. Brasília, v.3, n.1-2, jan-dez 2016.

RAUSCH, Aluizio Porcaro. O acúmulo intergeracional de riqueza tributação de heranças e doações no Brasil. Revista jurídica da Presidência, v. 17, n. 113, out/2015-jan/2016.

RAWLS, John. Uma teoria da justiça. Trad. Almiro Pisetta e Lenita M. R. Esteves. São Paulo: Martins Fontes, 1997.

. Some reasons for the maximin criterion. The American Economic Review, v. 64, n. 2, Papers and Proceedings of the Eighty-sixth Annual Meeting of the American Economic Association, mai. 1974.

RENNÓ JUNIOR, Lucio Remuzat; PEREIRA FILHO, Carlos Eduardo Ferreira. Gastos públicos, emendas orçamentárias do Legislativo e inclusão dissipativa nos municípios brasileiros: 1998 a 2010. Brasília: ESAF, 2013. Monografia premiada com o segundo lugar no XVIII Prêmio Tesouro Nacional - 2013.

RESENDE, André Lara. Devagar e simples: economia, Estado e vida contemporânea. 1. ed. São Paulo: Companhia das Letras, 2015.

RESENDE, Guilherme Mendes; MONTEIRO NETO, Aristides; MAGALHÃES, João Carlos; SOUSA, Alexandre Gervásio de; COSTA, Rodrigo Portugal da; SILVA, Diego Firmino Costa da. Uma proposta de avaliação continuada dos instrumentos da Política Nacional de Desenvolvimento Regional (PNDR). In: RESENDE, Guilherme Mendes (ed.). Avaliação de políticas públicas no Brasil: uma análise da Política Nacional de Desenvolvimento regional (PNDR). Brasília: IPEA, 2017.

10 anos da Política Nacional de Desenvolvimento regional (PNDR). BOLETIM ODR. Informativo sobre a ferramenta Observatório do Desenvolvimento Regional, Desenvolvimento Regional, Política Nacional de Desenvolvimento Regional - $\mathrm{n}^{\circ} 01$ (out. dez. 2014) - Brasília, DF; Ministério da Integração Nacional. Secretaria de Desenvolvimento Regional, 2014. 
REZENDE, Fernando. Federalismo fiscal: em busca de um novo modelo. In: OLIVEIRA, Romualdo Portela de; SANTANA, Wagner (Orgs.). Educação e federalismo no Brasil: combater as desigualdades, garantir a diversidade. Brasília: UNESCO, 2010.

Os desafios do federalismo fiscal. In: REZENDE, Fernando (Coord.). Desafios do federalismo fiscal. Rio de Janeiro: FGV, 2006.

REZZOAGLI, Luciano Carlos; REZZOAGLI, Bruno Ariel. Teoría de la igualdad intergeneracional: una perspectiva financiera y tributaria en la República Argentina. Revista Brasileira de Direito Tributário e Finanças Públicas, n. 33, jul-ago. 2012.

RIBEIRO, Eduardo; CANO, Ignacio. Vitimização letal e desigualdade no Brasil. Civitas Revista de Ciências Sociais, v. 16, n. 02, abr-jun. 2016.

RIBEIRO, José Aparecido Carlos; SCHERER, Clóvis. Anexo: Relato das oficinas sobre progressividade na tributação e desoneração da folha de pagamentos. In: RIBEIRO, José Aparecido Carlos; LUCHIEZI JR., Álvaro; MENDONÇA, Sérgio Eduardo Arbulu (Orgs.). Progressividade da tributação e desoneração da folha de pagamentos: elementos para reflexão. Brasília: IPEA: SINDIFISCO: DIEESE, 2001. p. 148.

RIBEIRO, Romiro. Orçamento público semi-impositivo para transferências voluntárias: diangóstco, perspectivas e proposta de mudanças. E-Legis, n. 4, $1^{\circ}$ semestre/2010.

RITTICH, Kerry. The future of law and development: second-generation reforms and the incorporation of the social. In: TRUBEK, David M.; SANTOS, Alvaro (Eds.). The new law and economic development, a critical appraisal. Cambridge University Press: 2006.ROCHA, C. Alexandre A. O FPM é constitucional? Núcleo de Estudos e Pesquisas do Senado Federal - Texto para Discussão n. 124, mar. 2013.

ROCHA, C. Alexandre A. Rateio do FPE: avaliação de impacto e de viabilidade legislativa das novas propostas. Texto para Discussão do Núcleo de Estudos e Pesquisas do Senado $\mathrm{n}$. 111, mar. 2012.

ROCHA, Camen Lúcia Antunes. Ação afirmativa: o conteúdo democrático do princípio da igualdade jurídica. Revista de Informação Legislativa, v. 33, n. 131, jul-set 1996.

RODRIGUES, Sirley Aparecida Lopes. A sistemática da progressividade tributária como mecanismo de igualdade. Revista Tributária e de Finanças Públicas, v. 117, jul-ago 2014.

RODRÍGUEZ GARAVITO, César. Más allá del desplazamiento, o cómo superar un estado de cosas inconstitucional. In: RODRÍGUEZ GARAVITO, César (Coord.). Más allá del desplazamiento: políticas, derechos y superación del desplazamiento forzado en Colombia. Bogotá: Universidad de los Andes, Facultad de Derecho, Edicion Uniandes, 2009.

RODRIGUEZ, José Rodrigo. Estado de coisas surreal. Jota, 25 set. 2015. Disponível em: https://www.jota.info/opiniao-e-analise/artigos/estado-de-coisas-surreal-25092015. Acesso em 02 mar. 2018.

RODRIGUEZ-GARAVITO, Cesar. Beyond the Courtroom: The Impact of Judicial Activism on Socioeconomic Rights in Latin America. Texas Law Review, v. 89, 2011.

RUBINSTEIN, Flávio. Promoção da equalização fiscal no federalismo brasileiro: o papel dos fundos de participação. In: CONTI, José Maurício; SCAFF, Fernando Facury; BRAGA, Carlos Eduardo Faraco (Org.). Federalismo fiscal: questões contemporâneas. Florianópolis: Conceito, 2010; 
SABAIINI, Juan Carlos Gómez; ROSSIGNOLO, Darío. La tributación sobre las altas rentas en América Latina. In: JIMÉNEZ, Juan Pablo (Ed.). Desigualdad, concentración del ingreso y tributación sobre las altas rentas en América Latina. Libros de la CEPAL, $\mathrm{N}^{\circ} 134$ (LC/G.2638-P), Santiago: CEPAL, 2015.

SACHS, Jeffrey. The price of civilization. New York: Random House, 2012.

SACHSIDA, Adolfo. Novas formas de tributação: imposto sobre movimentação financeira e impostos sobre grandes fortunas. In: SACHSIDA, Adolfo (Org.). Tributação no Brasil: estudos, ideias e propostas: ICMS, seguridade social, carga tributária, impactos econômicos. Brasília: IPEA, 2017.

SAINZ DE BUJANDA, Fernando. Hacieda y derecho: introducción al derecho financiero de nostro tiempo. Madrid: Instituto de Estudios Políticos, 1975.

SALDANHA, Nelson. O jardim e a praça: ensaio sobre o lado "privado" e o lado "público" da vida social e histórica. Revista Ciência \& Trópico, vol 11, n. 1, jan-jun1983.

SALES, Jó Bezerra de. Transferências Intergovernamentais: a desigualdade na repartição da cota-parte do ICMS no Pará - 1998 a 2008. Brasília: ESAF, 2010. Monografia premiada com o terceiro lugar no XV Prêmio Tesouro Nacional - 2010: Homenagem a Joaquim Nabuco. Tópicos Especiais de Finanças Públicas. Belém (PA).

SALOMÃO FILHO, Calixto; FERRÃO, Brisa Lopes de Mello; RIBEIRO, Ivan César. Concentração, estruturas e desigualdade: as origens coloniais da pobreza e da má distribuição de renda. São Paulo: IDCID, 2006.

SALTO, Felipe Scudeler. A economia política das transferências fiscais no Brasil: o Fundo de Participação dos Estados (FPE) contribuiu no processo de redução das disparidades regionais entre 1985 e 2009? Dissertação (Mestrado). Escola de Administração de Empresas de São Paulo da Fundação Getúlio Vargas. São Paulo, 2013.

SALVADOR, Evilasio. As implicações do sistema tributário brasileiro nas desigualdades de renda. 1. ed. Brasília: INESC; OXFAM, 2014.

SALVADOR, Evilásio. Renúncias tributárias: os impactos no financiamento das políticas sociais no Brasil. Brasília: INESC - Instituto de Estudos Socioeconômicos, 2015.

SALVERDA, Wiemer; NOLAN, Brian; SMEEDING, Timothy M. Introduction. In: SALVERDA, Wiemer; NOLAN, Brian; SMEEDING, Timothy M. (Eds.). The Oxford handbook of economic inequality. Oxford University Press, 2009.

SAMPAIO DÓRIA, Antônio Roberto. Discriminação de rendas tributárias. São Paulo: José Bushatsky Editor, 1972.

Princípios constitucionais tributários e a cláusula Due Process of Law. Tese (Livre Docência). Universidade de São Paulo. São Paulo, 1964.

SAMPAIO, Gabriela Thomazinho Clementino; OLIVEIRA, Romualdo Portela de. Dimensões da desigualdade educacional no Brasil. Revista Brasileira de Política e Administração da Educação, v. 31, n. 3, 2015.

SANDBU, Martin. Inequality does not merit fatalism. Financial Times, 19 dez. 2017. Disponível em: https://www.ft.com/content/56a31624-e3ef-11e7-8b99-0191e45377ec. Acesso em 30 dez. 2018. 
SANT'ANNA E SILVA, Sebastião de. Os princípios orçamentários. $2^{\mathrm{a}}$ impr. Rio de Janeiro: Fundação Getúlio Vargas, 1962.

SANTOS, Ângela Penalva. Tributação imobiliária no Brasil: um difícil percurso rumo à política urbana. Finisterra - Revista Portuguesa de Geografia, XLIX, 97, 2014.

SANTOS, Cláudio Hamilton Matos dos; SCHETTINI, Bernardo Patta; VASCONCELOS, Lucas; AMBROSIO, Érica Lima. A dinâmica dos gastos com saúde e educação públicas no Brasil (2006-2015): impacto dos mínimos constitucionais e relação com a arrecadação tributária. Texto para Discussão IPEA n. 2289, abr-2017.

SANTOS, Darcy Francisco Carvalho dos. Situação financeira dos Estados em dez anos da Lei de Responsabilidade Fiscal (2000-2009). Brasília: ESAF, 2010. Monografia premiada com menção honrosa no XV Prêmio Tesouro Nacional - 2010: Homenagem a Joaquim Nabuco. Política Fiscal e Sustentabilidade do Crescimento. Porto Alegre (RS).

SANTOS, Élvio Gusmão. Desigualdade social e justiça tributária. Disponível em: <http://www.agu.gov.br/page/download/index/id/905012> Acesso em 12 fev. 2018.

SANTOS, Helena Maria Pereira dos; VIEIRA, José Ribas; DAMASCENO, Luana Regina D'Alessandro; CHAGAS, Tayná Tavares das. Estado de coisas inconstitucional: um estudo sobre os casos colombiano e brasileiro. Quaestio Juris, v. 08, n. 04, número especial, 2015.

SANTOS, Ramon Tomazela. A progressividade do Imposto de Renda e os desafios de política fiscal. Revista Direito Tributário Atual n. 33. São Paulo: IBDT/Dialética, 2015.

SARAIVA FILHO, Oswaldo Othon de Pontes. A não correção da tabela do IRPF. Revista Virtual da $A G U$, ano II n. 16, nov. 2001. Disponível em: <http://www.agu.gov.br/page/download/index/id/886208> Acesso em 17 jan. 2018.

SARLO, Oscar. Republicanismo, derechos humanos y deberes tributarios. Revista Mestrado em Direito, ano 12, n. 1, Osasco, jan-jul. 2012.

SARMENTO, Daniel. O neoconstitucionalismo no Brasil: riscos e possibilidades. In: LEITE, George Salomão; SARLET, Ingo Wolfgang (Coord.). Direitos fundamentais $e$ estado constitucional: estudos em homenagem a J.J. Gomes Canotilho. São Paulo: RT, 2008.

Ubiquidade constitucional: os dois lados da moeda. In: SARMENTO, Daniel; SOUZA NETO, Cláudio Pereira de (Orgs.). A Constitucionalização do Direito: fundamentos teóricos e aplicações específicas. Rio de Janeiro: Lumen Juris, 2006.

SÁTYRO, Natália Guimarães Duarte. Política estadual e desigualdade: por que alguns Estados redistribuem mais do que outros? DADOS - Revista de Ciência Sociais, v. 56, n. 03, 2013.

SAYER, Andrew. We need to challenge the myth that the rich are specially-talented wealth creators. LSE Blog. Disponível em : http://blogs.lse.ac.uk/politicsandpolicy/we-need-tochallenge-the-myth-that-the-rich-are-specially-talented-wealth-

creators/?utm_content=bufferbb9e9\&utm_medium=social\&utm_source=twitter.com\&utm campaign=buffer. Acesso em 29 abr. 2018

SCAFF, Fernando Facury. A inconstitucional unanimidade do Confaz e o surpreendente Convênio 70. Consultor Jurídico, 12 ago. 2014. Disponível em: 
<http://www.conjur.com.br/2014-ago-12/contas-vista-inconstitucional-unanimidadeconfaz-convenio-70> Acesso em 04 fev. 2018.

Orçamento republicano e liberdade igual: direito financeiro, república e direitos fundamentais. Tese (Concurso para provimento do cargo de Professor Titular de Direito Financeiro) Universidade de São Paulo. São Paulo, 2017.

Não há democracia sem Estado Social: saudação a Avelãs Nunes no STF. Revista Fórum de Direito Financeiro e Econômico, ano 06, n. 11, mar-ago 2017.

. Liberdade do legislador orçamentário e não afetação: captura versus garantia dos direitos sociais. Revista Fórum de Direito Financeiro e Econômico, ano 05, n. 08, set-fev 2016.

Crédito público e sustentabilidade financeira. Revista Fórum de Direito Financeiro e Econômico, v. 5, 2014.

Guerra fiscal e súmula vinculante: entre o formalismo e o realismo. In: ROCHA, Valdir de Oliveira (Org.). Grandes questões atuais do direito tributário, v. 18. São Paulo: Dialética, 2014.

Royalties do petróleo, minério e energia: aspectos constitucionais, financeiros e tributários. 1. ed. São Paulo: Editora Revista dos Tribunais, 2014.

Royalties do petróleo, minério energia: aspectos constitucionais, financeiros e tributários. São Paulo: Editora Revista dos Tribunais, 2014.

Royalties decorrentes da exploração de recursos naturais não renováveis: incidência e rateio federativo. 2013. Tese (Livre-Docência) Faculdade de Direito da Universidade de São Paulo.

Recuperação dos Créditos Acumulados de ICMS na exportação. In: ROCHA, Valdir Oliveira da (Org.). Grandes questões atuais de direito tributário, v. 16. São Paulo: Dialética, 2012.

.; AVELÃS NUNES, António José. Os tribunais e o direito a saúde no Brasil. Porto Alegre: Livraria do Advogado, 2011.

.. Sentenças aditivas, direitos sociais e reserva do possível. In: SARLET, Ingo Wolfgang; TIMM, Luciano Benetti (Orgs.). Direitos fundamentais, orçamento e "reserva do possível”. 2. ed. rev. e ampl. Porto Alegre: Livraria do Advogado Editora, 2010.

; SILVEIRA, Alexandre Coutinho da. Competência tributária, transferências obrigatórias e incentivos fiscais. In: CONTI, José Maurício; SCAFF, Fernando Facury; BRAGA, Carlos Eduardo Faraco (Org.). Federalismo fiscal: questões contemporâneas. Florianópolis: Conceito, 2010.

Como a sociedade financia o Estado para a implementação dos direitos humanos? In: MIRANDA COUTINHO, Jacinto Nelson; BOLZAN DE MORAIS, José Luiz; STRECK, Lenio Luiz (org.). Estudos constitucionais. Rio de Janeiro: Renovar, 2007.

Aspectos financeiros do sistema de organização territorial do Brasil. Revista Dialética de Direito Tributário, n. 112, jan. 2005.

. O jardim e a praça ou a dignidade da pessoa humana e o direito tributário e financeiro. In: TORRES, Heleno Taveira (Coord.). Direito e poder nas instituições e nos 
valores do público e do privado contemporâneos - Estudos em homenagem a Nelson Saldanha. Barueri: Manole, 2005.

. Direitos Humanos e a Desvinculação das Receitas da União - DRU. In: FISCHER, Octavio Campos (Coord.). Tributos e Direitos Fundamentais. São Paulo: Dialética, 2004.

SCALON, Celi; SALATA, André. Apresentação. Civitas - Revista de Ciências Sociais, v. 16, n. 02, abr-jun 2016.

SCHEIDEL, Walter. The great leveler: violence and the history of inequality from the stone age to the twenty-first century. Princeton : Princeton University Press, 2017

SCHEVE, Kenneth; STASAVAGE, David. Taxing the rich: a history of fiscal fairness on the United States and Europe. New York, Priceton, Oxford : Russel Sage Foundation, Princeton University Press, 2016.

SCHICK, Allen. Sustainable budget policy: concepts and approaches. OECD Journal on Budgeting, vol 5, n. 1. OECD, 2005.

SCHOUERI, Luís Eduardo. Direito Tributário. São Paulo: Saraiva, 2011.

Planejamento tributário: limites à norma antiabuso. Revista Direito Tributário Atual, n. 24. IBDT/Dialética, 2010.

Tributação e indução econômica: os efeitos econômicos de um tributo como critério para sua constitucionalidade. In: FERRAZ, Roberto (coord.). Princípios e Limites da Tributação 2 - Os Princípios da Ordem Econômica e a Tributação. São Paulo: Quartier Latin, 2009.

. Livre concorrência e Tributação. In ROCHA, Valdir de Oliveira (coord.). Grandes Questões Atuais do Direito Tributário - v. 11. São Paulo: Dialética, 2007.SCHOUERI, Luís Eduardo. Normas tributárias indutoras e intervenção econômica. Rio de Janeiro: Forense, 2005.

SCHWARCZ, Lilia. Desigualdade é teimosia social. Nexo Jornal, 09 out. 2017.

.; e STARLING, Heloisa Murgel. Brasil: uma biografia. $1^{\text {a }}$ ed. São Paulo: Companhia das Letras, 2015.

SECRETARIA DE ASSUNTOS ECONÔMICOS - SEAE Efeito redistributivo da política fiscal no Brasil. Brasília, 2017.

Orçamento de subsídios da União: Relatório do Governo Federal sobre a evolução dos gastos tributários e benefícios financeiros e creditícios no período 2003 a 2016. Brasília, 2017.

SECRETARIA DE POLÍTICA ECONÔMICA, 2015. Notas de análise sobre a desoneração da folha. Disponível em: < http://www.fazenda.gov.br/centrais-de-conteudos/notastecnicas/2015/notas-de-analise-sobre-desoneracao-da-folha-spe-2013-

02.04.2015/Desoneracao-Versao-Abril-2-2-2.pdf -> Acesso em 09 ago. 2016.

SECRETARIA DO TESOURO NACIONAL. Manual de Demostrativos Fiscais: aplicado à União e aos Estados, Distrito Federal e Municípios. $8^{\mathrm{a}}$ edição. Brasília: Secretaria do Tesouro Nacional, Subsecretaria de Contabilidade Pública, Coordenação-Geral de Normas de Contabilidade Aplicadas à Federação, 2017.

. Transferências voluntárias a estados, Distrito Federal e municípios - dez. 2014. 
O que você precisa saber sobre as transferências constitucionais e legais: Fundo de Participação dos Municípios. Brasília, 2013.

SENADO FEDERAL. CONSULTORIA LEGISLATIVA. Estudo n. 463, 2015: Referente à STC n. 2015-00903, da Senadora Gleisi Hoffmann, que requer estudo acerca do imposto sobre grandes fortunas. Brasília: Senado Federal, 2015.

. Proposta de Sistema Tributário. Brasília, 2010.

SELIGMAN, Edwin R. A. The income tax: a study of the history, theory, and practice of income taxation at home and abroad. New York: The Macmillan Company, 1911.

Progressive taxation in theory and practice. Publications of the American Economic Association, v. 09, n. 01/02, jan-mar-1894

SHAH, Anwar. Introduction: principles of fiscal federalism. In: SHAH, Anwar (Ed.). The practice of fiscal federalism: comparative perspectives. A global dialogue on federalism. Canadá: McGill-Queen’s University Press, 2007. v. 4.

SILVA, Alexandre M. A. da; MONTEIRO NETO, Aristides; GERARDO, José Carlos. Dívidas estaduais, federalismo fiscal e desigualdades regionais no Brasil. IPEA - texto para discussão n. 1889. Rio de Janeiro, out. 2013.

SILVA, Mauro Santos. Teoria do federalismo fiscal: notas sobre as contribuições de Oates, Musgrave, Shah e Ter-Minassian. Belo Horizonte: Nova Economia, 2005.

SILVEIRA, André Bueno da. Doutrina Chevron no Brasil: uma alternativa à insegurança jurídica. RDA - Revista de Direito Administrativo, v. 275, mai-ago. 2017.

SILVEIRA, Alexandre Coutinho da. Isenções tributárias: da conotação individual-tributária à público-financeira em 50 anos. In: VIANA, Michel. Código Tributário Nacional: análises e reflexões para mais 50 anos de vigência. São Paulo: Quartier Latin, 2016.

SILVEIRA, Alexandre Coutinho da; SCAFF, Fernando Facury. Incentivos fiscais na federação brasileira. In: MACHADO, Hugo de Brito (Coord.). Regime jurídico dos incentivos fiscais. São Paulo: Malheiros Editores; ICET - Instituto Cearense de Estudos Tributários, 2015.

SILVEIRA, Alexandre Coutinho da. Orçamento e planejamento: tensões entre poderes. Revista Fórum de Direito Financeiro e Econômico, v. 04, n. 06, set 2014- fev 2015.

SILVEIRA, Alexandre Coutinho da. Governança pública de royalties: federalismo fiscal e futuras gerações. Dissertação (Mestrado). Faculdade de Direito da Universidade de São Paulo. São Paulo, 2014.

SILVEIRA, Fernando Gaiger. Concentração de renda. Revista GV Executivo, v. 07, n. 04, jul-ago 2008.

SILVEIRA, Fernando Gaiger; REZENDE, Fernando; AFONSO, José Roberto; FERREIRA, Jhonatan. Fiscal equity: distributional impacts of taxation and social spending in Brazil. IDP-UNDP Working Paper n. 115. Brasília, out. 2013.

SIMÃO, Juliana Barby; ORELLANO, Veronica Ines Fernandez. Um estudo sobre a distribuição das transferências para o setor de saúde no Brasil. Estudos Econômicos, São Paulo, [S.1.], v. 45, n. 1, p. 33-63, jan. 2015.. Disponível em: <<http://www.Revistas.usp.br/ee/article/view/69684> Acesso em: 30 jun. 2015. 
SIMÃO, Juliana Barby; ORELLANO, Veronica Ines Fernandez. Um estudo sobre a distribuição das transferências para o setor de saúde no Brasil. Estudos Econômicos, v. 45, n. 1, jan-mar. 2015.

SIMIELLO, Lara Elena Ramos. Equidade educacional no Brasil: análise das oportunidades educacionais em 2001 e 2011. Tese (Doutorado). Escola de Administração de Empresas de São Paulo da Fundação Getúlio Vargas. São Paulo, 2015

SINDIFISCO NACIONAL. A defasagem na correção da tabela do Imposto de Renda Pessoa Física. Brasília, jan-2018. Disponível em: $<\mathrm{http}$ //www.sindifisconacional.org.br/index.php?option=com_content\&view=category\&la yout=blog\&id=181\&Itemid=384> Acesso em 17 jan. 2018.

SOARES DE MELO, José Eduardo. Curso de direito tributário. 7. ed. São Paulo: Dialética, 2007.

SOARES, Márcia Miranda. Repasses financeiros e voluntários da União aos Municípios brasileiros: condicionantes políticos, sociais e técnicos (Resultado Parcial de Pesquisa Financiada pelo Conselho Nacional de Desenvolvimento Científico e Tecnológico - CNPq). $8^{\circ}$ Encontro da Associação Brasileira de Ciência Política. Gramado, ago-2012.

SOARES, Sergei Suarez Dillon. O ritmo na queda da desigualdade no Brasil é aceitável? Revista de Economia Política, v. 30, p. 364-380, 2010.

. O ritmo na queda da desigualdade no Brasil é aceitável? Cit. Nesse sentido, ver ainda: SILVEIRA, Fernando Gaiger. Concentração de renda. Revista GV Executivo, v. 07, n. 04, jul-ago. 2008.

SOCI, Anna; MACCAGNAN, Anna; MANTOVANI, Daniela. Does inequality harm democracy? An empirical investigation on the UK. Dipartimento Scienze Economiche, Universitá di Bologna, Quaderni Working Paper DSE n 935, 2014. p. 29.

SOKOLOFF, Kenneth L.; ZOLT, Eric M. Inequality and taxation: evidence from the Americas on how inequality may influence tax institutions. Tax Law Review, v. 59, n. 2. 2006.

SOUSA FRANCO, António L. Finanças públicas e Direito Financeiro. v. I. 4. ed., 11 ${ }^{\mathrm{a}}$ reimpr. Coimbra: Almedina, 2007.

SOUSA, Rubens Gomes de. Estudos de direito tributário. São Paulo: Edição Saraiva, 1950.

SOUZA, Celina. Federalismo, desenho constitucional e instituições federativas no brasil pós-1988. Revista de Sociologia e Política, Curitiba, N. 24, 2005.

SOUZA, Celina. Intermediação de Interesses Regionais no Brasil: O Impacto do Federalismo e da Descentralização. Dados, Rio de Janeiro, v. 41, n. 3, 1998. Disponível em: $<$ http://www.scielo.br/scielo.php?script=sci_arttext\&pid=S0011-

52581998000300003\&lng=en\&nrm=iso> Acesso em 29 nov. 2015.

SOUZA, Pedro Herculano Guimarães Ferreira de. A desigualdade vista do topo: a concentração de renda entre os ricos no Brasil, 1926-2013. Tese (Doutorado). Universidade de Brasília. Brasília, 2016. 
STACEY, Richard. Dynamic regulatory constitutionalism: taking legislation seriously in the judicial enforcement of economic and social rights. Notre Dame Journal of Law, Ethics \& Public Policy, v. 31, n. 01, 2017.

STEPAN, Alfred. Para uma nova análise comparativa do federalismo e da democracia: federações que restringem ou ampliam o poder do Demos. Dados, Rio de Janeiro, v. 42, n. 2, 1999. Disponível em: <http://dx.doi.org/10.1590/S0011-52581999000200001> Acesso em 05 fev. 2018.

STIGLITZ, Joseph E. Pareto efficient taxation and expenditures: pre- and re-distribution. NBER Workng paper n. 23892. out. 2017.

The great divide. Unequal societies and what we can do about them. New York: W.W. Norton \& Company, 2015.

The price of inequality: how today's divided society endangers our future. NY: W. W. Norton \& Company, 2012.

STRECK, Lenio Luiz. Estado de Coisas Inconstitucional é uma nova forma de ativismo. Consultor Jurídico, 24 out. 2015. Disponível em: https://www.conjur.com.br/2015-out24/observatorio-constitucional-estado-coisas-inconstitucional-forma-ativismo. Acesso em 20 mar. 2018.

; MORAIS, Jose Luiz Bolzan de. Comentário ao art. $3^{\circ}$. In: CANOTILHO, J. J. Gomes; MENDES, Gilmar Ferreira; SARLET, Ingo Wolfgang; STRECK, Lenio Luiz (Coord. científica); LEONCY, Léo Ferreira (Coord. executiva). Comentários à Constituição do Brasil. São Paulo: Saraiva/Almedina, 2013.

STREECK, Wolfgang. O retorno do recalcado: o começo do fim do capitalismo neoliberal. Revista Piauí, ed. 135, de dez. 2017.

SUNDELSON, J. Wilner. Budgetary principles. Political Science Quarterly, v. 50, n. 02, jun. 1935.

SURREY, Stanley S. Tax Incentives as device for implementing government policy: a comparison with direct government expenditures. Harvard Law Review, v. 83, n. 4, fev. 1970 .

SZELBRACIKOWSKI, Daniel Corrêa. Guerra fiscal de ICMS no Brasil: exame sobre a unanimidade exigida para a concessão de incentivos fiscais no Conselho Nacional de Política Fazendária (CONFAZ). Dissertação (Mestrado). Instituto Brasiliense de Direito Público. Brasília, 2016.

TANNO, Claudio Riyudi. Universalização, qualidade e equidade na alocação de recursos do Fundo de Manutenção e Desenvolvimento da Educação Básica e de Valorização dos Profissionais da Educação (FUNDEB): proposta de aprimoramento para a implantação do Custo Aluno Qualidade (CAQ). Estudo Técnico n. 24/2017. Brasília: Câmara dos Deputados: Consultoria de Orçamento e Fiscalização Financeira, out-2017.

TANZI, Vito. Rethinking fiscal federalism: a critical evaluation. Mimeo (Paper escrito para o " $180^{\circ}$ Seminario Federalismo Fiscal 2015", promovido pela Facultad de Ciencias Economicas - Universidad Nacional de Buenos Aires, em 05 jun. 2015). 2015.

Budget institutions and fiscal policy in Brazil. Rivista Di Diritto Finanziario e Scienza Delle Finanze, Anno LXXIV, Fasc. 3. 2015. 
Taxation and equitable economic development: a historical note. 2014. Disponível em : https://www.wilsoncenter.org/sites/default/files/VitoTanzi_2014_final.pdf> Acesso em 20 abr. 2018

TAPOROSKY, Barbara Cristina Hanauer. O valor anual mínimo por aluno do FUNDEB, o CAQi e a reserva do possível. FINEDUCA - Revista de Financiamento da Educação, v. 06, n. 06, 2016.

TELES, Andrei Souza; COELHO, Thereza Christina Bahia; FERREIRA, Milla Pauline da Silva. Gasto Público em saúde na Bahia: explorando indícios de desigualdades. Saúde em Debate, v. 41, n. 113, abr,/jun-20017..

TEODOROVICZ, Jeferson. Tributação ótima, tributo justo, ciência do Direito Tributário no Brasil e Direito Financeiro. Cadernos da Escola de Direito e Relações Internacionais da UNIBRASIL, v. 2, n. 23, jul-dez. 2015.

TER-MINASSIAN, Teresa. Elusive goal: Brazil's subnational revenue system reform. In: CIBILS, Vicente Fretes; TER-MINASSIAN, Teresa (Eds.). Decentralizing revenue in Latin America: why and how. Washington: Inter-American Development Bank, 2015.

, Teresa. More than revenue: main challenges for taxation in Latin America and the Caribbean. Inter-American Development Bank Working Paper, n. IDB-PB-175, 2012.

Reforma do Fundo de Participação dos Estados (FPE). Texto para Debate do Banco Interamericano de Desenvolvimento n. IBD-DP-216. 2012.

Intergovernmental fiscal relations in a macroeconomic perspective: an overview. In: TER-MINASSIAN, Teresa (Ed.). Fiscal federalism in theory and practice. Washington: International Monetary Fund, 1997.

TILBERY, Henry. O conceito de "essencialidade" como critério de tributação. Revista Direito Tributário Atual, v. 10, 1990.

Reflexões sobre a Tributação do Patrimônio. In Imposto de Renda - Estudos. n. 4. São Paulo: Resenha Tributária, 1987.

Inflação e tributação. In: MACHADO, Brandão (Coord.). Direito tributário: estudos em homenagem ao Prof. Ruy Barbosa Nogueira. São Paulo: Saraiva, 1984.

TILLY, Charles. Polish Sociological Review, n. 151, 2005.

TIPKE, Klaus; LANG, Joachim. Direito Tributário, v. I, traduzido por Luiz Dória Furquim. Porto Alegre: Sergio Antonio Fabris Editor, 2008.

; YAMASHITA, Douglas. Justiça fiscal e princípio da capacidade contributiva. 1. ed. São Paulo: Malheiros Editores, 2002;

- Princípio da igualdade e ideia de sistema no direito tributário. Tradução de Brandão Machado. In: MACHADO, Brandão (Coord.). Direito tributário: estudos em homenagem ao Prof. Ruy Barbosa Nogueira. São Paulo: Saraiva, 1984.

TKINSON, Anthony B. Desigualdade: o que pode ser feito? Tradução de Elisa Câmara. São Paulo: LeYa, 2015.

TOLENTINO FILHO, Pedro Delarue. Progressividade da tributação e justiça fiscal: algumas propostas para reduzir as inequidades do sistema fiscal brasileiro. In: RIBEIRO, José Aparecido Carlos; LUCHIEZI JR., Álvaro; MENDONÇA, Sérgio Eduardo Arbulu 
(Orgs.). Progressividade da tributação e desoneração da folha de pagamentos: elementos para reflexão. Brasília: IPEA: SINDIFISCO: DIEESE, 2001.

TOMÉ, Fabia del Padre; PACOBAHYBA, Fernanda Mara Macedo. O IPVA e as polêmicas em torno da abrangência da expressão "veículos automotores" e da diferenciação de alíquotas em função dos "tipos" de veículos - Reflexões acerca da ADI N ${ }^{o}$ 5654. 2018. Disponível em: <http://www.ibet.com.br/wp-content/uploads/2018/02/Fabiana-Del-PadreTome-e-Fernanda-Mara-Macedo-Pacobahyba.pdf> Acesso em 25 mar. 2018.

TORCHE, Florencia. Intergenerational mobility and inequality: the latin american case. Annual review of Sociology, v. 40. 2014. Disponível em: <https://doi.org/10.1146/annurevsoc-071811-145521> Acesso em 18 fev. 2018.

TORRES, Ernani; ZEIDAN, Rodrigo. The life-cycle of national development banks: The experience of Brazil's BNDES. The Quarterly Review of Economics and Finance, v. 62, nov. 2016.

TORRES, Heleno Taveira. A justiça dos tributos. In: DERZI, Misabel Abreu Machado; MELO, João Paulo Fanucchi de Almeida (Coord.). Justiça Fiscal. Belo Horizonte: Del Rey, 2016.

Direito constitucional financeiro: teoria da Constituição Financeira. São Paulo: Editora Revista dos Tribunais, 2014.

Teoria da Constituição Financeira. Tese (Concurso para provimento de cargo de Professor Titular). Faculdade de Direito da Universidade de São Paulo. São Paulo, 2014.

TORRES, Ricardo Lobo. Tratado de direito constitucional financeiro e tributário. v. IV. Rio de Janeiro: Renovar, 2007.

O princípio constitucional orçamentário da não-afetação. Revista de Direito do Estado, n. 6, abr-jun. 2007.

. Tratado de direito constitucional financeiro e tributário. v. II. Rio de Janeiro: Renovar, 2005.

Ética e justiça tributária. In: SCHOUERI, Luís Eduardo; ZILVETI, Fernando Aurélio. Direito tributário: estudos em homenagem a Brandão Machado. São Paulo: Dialética, 1998.

TRUBEK, David M.; SANTOS, Alvaro (Eds.). The new law and economic development, a critical appraisal. Cambridge University Press: 2006.

TRUFFI, Renan. Imposto sobre grandes fortunas renderia 100 bilhões por ano. Carta Capital. Publicado em 03 mar. 2015. O entrevistado não declina seu método com exatidão. A opinião de Khair também pode ser encontrada em: KHAIR, Amir. Imposto sobre grandes fortunas $\quad(I G F)$. Mimeo. Disponível em: <http://www.ie.ufrj.br/aparte/pdfs/akhair190308_2.pdf> Acesso em 13 fev. 2018.

UGÁ, Maria Alicia Dominguez; SANTOS, Isabela Soares. Uma análise da progressividade do financiamento do Sistema Único de Saúde (SUS). Cadernos de Saúde Pública, Rio de Janeiro, 22 (8): 1597-1609. ago. 2006. 
UNAFISCO NACIONAL. Perguntas e respostas: securitização dos créditos tributários parcelados. Disponível em: <http://unafisconacional.org.br/img/publica_pdf/CartilhaSecuritizacao-Unafisco.PDF> Acesso em 11 mar. 2018.

UNDP. Human Development Report 2016.

VALCÁRCEL, Ernesto Lejeune. O princípio de igualdade. In: FERRAZ, Roberto Catalano Botelho (Coord.). Princípios e limites da tributação 2. São Paulo: Quartier Latin, 2009.

VALENTE, Antônio Sérgio. Robin Hood às avessas: a substituição tributária paulista. Cartas do Fiscal - Série Justiça Tributária, N. 1, out-2011. Disponível em: $<$ https://proafr.files.wordpress.com/2011/10/cartasdofiscalrobinhood5.pdf> Acesso em 04 fev. 2018.

VALLE, Maurício Dalri Timm do. O princípio da seletividade do IPI. Cadernos da Escola de Direito da UNIBRASIL, v. 1, n. 17, 2012. Disponível em: <http://revistas.unibrasil.com.br/cadernosdireito/index.php/direito/article/view/821> Acesso em 02 fev. 2018.

VAREJÃO, José Ricardo do Nascimento. Princípio da igualdade e direito tributário. São Paulo: MP Editora, 2008.

VARSANO, Ricardo. A tributação do valor adicionado, o ICMS e as reformas necessárias para conformá-lo às melhores práticas internacionais. BID: Documento para discussão \# IDB-DP-335. fev. 2014.

- A evolução do sistema tributário brasileiro ao longo do século: anotação e reflexões para futuras reformas. 1996. Texto para Discussão IPEA n. 405, jan. 1996.

O imposto predial e territorial urbano: receita, equidade e adequação aos municípios. Revista Pesquisa e Planejamento Econômico, v. 7, n. 3. Rio de Janeiro, dez. 1977.

VAZQUEZ, Daniel Arias. Mecanismos institucionais de regulação federal e seus resultados nas políticas de educação e saúde. Dados, v. 57, n. 4, dez. 2014.

Fundos multigovernamentais e seus efeitos redistributivos no financiamento da educação: um balanço final do Fundef e uma avaliação da implantação do Fundeb. XVI Prêmio Tesouro Nacional - 2011.

- A regulação federal como mecanismo de ajuste: uma análise da lei fiscal e do financiamento das políticas de educação e saúde. Tese (Doutorado). Campinas: UNICAMP, 2010.

.; HÖFLING, Daniel de Mattos; CAJUEIRO, Juliana Pinto de Moura; MONFREDINI, Maria Isabel. Política econômica e política social no Brasil nos anos 1990: possibilidades, limites e condicionantes. Revista Economia e Sociedade, v. 13, n. 02, jul dez. 2004.

Educação, descentralização e desequilíbrios regionais: os impactos do FUNDEF. Dissertação (Mestrado). Campinas: UNICAMP, 2003.

VELLOSO, Andrei Pitten. A teoria da igualdade tributária e o controle de proporcionalidade das desigualdades de tratamento. In: MARTINS, Ives Gandra da Silva; BRITO, Edvaldo 
(Orgs.). Direito tributário: princípios e normas gerais (Coleção doutrinas essenciais, v. 1). 2. ed. ampl. São Paulo: Editora Revista dos Tribunais, 2014.

VELOSO, Juliano Ribeiro Santos. Direito ao planejamento. Belo Horizonte: Editor D’Plácio, 2014.

VERBICARO, Loiane Prado. Um estudo sobre as condições facilitadoras da judicialização da política no Brasil. Revista Direito GV, v. 04, n. 02, jul-dez. 2008.

VERÍSSIMO, Marcos Paulo. A judicialização dos conflitos de justiça distributiva no Brasil: o processo judicial no pós-1988. Tese (Doutorado). Universidade de São Paulo. São Paulo, 2006.

VIANA, Michel. Código Tributário Nacional: análises e reflexões para mais 50 anos de vigência. São Paulo: Quartier Latin, 2016.

VICTOR, Sérgio Antônio Ferreira. Diálogo institucional, demoracia e Estado de Direito: o debate entre o Supremo Tribunal Federal e o Congresso Nacional sobre a interpretação da Constituição. Tese (Doutorado). Universidade de São Paulo. São Paulo, 2013.

VIDIGAL, Geraldo. Teoria geral do direito econômico. São Paulo: Ed. Revista dos Tribunais, 1977.

VIDIGAL, Geraldo de Camargo. Fundamentos do direito financeiro. São Paulo: Ed. Revista dos Tribunais, 1973.

VIEIRA JUNIOR, Ronaldo Jorge Araújo. Separação de Poderes, Estado de Coisas Inconstitucional e Compromisso Significativo: novas balizas à atuação do Supremo Tribunal Federal. Brasília: Núcleo de Estudos e Pesquisas/CONLEG/Senado, dez-2015 (Texto para Discussão n. 186).

VIEIRA, José Ribas; BEZERRA, Rafael. Estado de coisas fora do lugar (?). Jota, 05 out. 2015. Disponível em: https://www.jota.info/opiniao-e-analise/artigos/estado-de-coisas-foralugar-05102015. Acesso em 20 mar. 2018.

VIEIRA, Oscar Vilhena. A naturalização da desigualdade. Opinião. Folha de São Paulo, 30 set. 2017.

. Supremocracia. Revista Direito GV, v. 04, n. 02, jul-dez 2008.

A desigualdade e a subversão do Estado de Direito. SUR - Revista Internacional de Direitos Humanos, n. 06, ano 04, 2007.

- Direitos fundamentais: uma leitura da jurisprudência do STF. São Paulo: Malheiros Editores, 2006

VILLAS-BÔAS, Marcos de Aguiar. O Simples Nacional e a armadilha da pequena empresa. Carta Capital, 30 set. 2016

VIVEIROS DE CASTRO, João Pedro Almeida. Novos olhares sobre o princípio da capacidade contributiva. Revista Tributária e de Finanças Públicas, v. 112, Set/Out 2013.

WALDMANN, Robert. Income distribution and infant mortality, Quarterly Journal of Economics, v. 107, n. 04, nov. 1992. 
WARREN, Neil. A review of studies on the distributional impact of con.sumption taxes in OECD countries. OECD Social, Employment and Migration Working Papers n. 64, DELSA/ELSA/WD/SEM(2008)1, jun. 2008.

WEIL, Patrick. An international tax on the wealthiest citizens of the world. Disponível em : http://www.policy-network.net/pno_detail.aspx?ID=4006>Acesso em 13 fev. 2018.

WEISS, Edith Brown. In fairness to future generations: international law, common patrimony, and intergenerational equity. Tokyo: The United Nations University, 1989.

WERNECK VIANN, Luiz; BURGOS, Marcelo Baumann; SALLES, Paula Martins. Dezessete anos de judicialização da política. Tempo Social, v. 19, n. 02, nov. 2007.

WEST, Max. The theory of the inheritance tax. Political Science Quarterly, v. 8, n. 3, set.1893.

WIGTON-JONES, Evan. Legacies of inequality: the case of Brazil. 2017. Disponível em: $<$ http://economics.ucr.edu/job_candidates/Wigton-Jones-Paper.pdf> Acesso em 03 abr. 2018.

WILKINSON, Richard; PICKETT, Kate. The spirit level: why greater equality makes societies stronger. New York : Bloomsbury Press, 2009.

YERGIN, Daniel. The 42.35\% Chance: A chat with Greenspan. 28 set. 2007. Disponível em: <https://www.cnbc.com/id/20887009> Acesso em 05 abr. 2018.

ZOCKUN, Maria Helena. Equidade na tributação. In: AFONSO, José Roberto; LUKIC, Melina Rocha; ORAIR, Rodrigo Octávio; SILVEIRA, Fernando Gaiger (Orgs.). Tributação e desigualdade. Belo Horizonte: Letramento: Casa do Direito: FGV Direito Rio, 2017.

ZOLT, Eric M. Inequality, collective action, and taxing and spending patterns of state and local governments. Tax Law Review, v. 62, n. 04, 2009. 